AGGREGATION OF MINNESOTA WATER-USE DATA AND TRANSFER OF DATA

TO THE NATIONAL WATER-USE DATA SYSTEM:

PROCEDURES AND PROGRAMS

By L. C. Trotta

U.S. GEOLOGICAL SURVEY

Open-File Report $87-40$

Prepared in cooperation with the

MINNESOTA DEPARTMENT OF NATURAL RESOURCES

and the MINNESOTA STATE PLANNING AGENCY

St. Paul, Minnesota

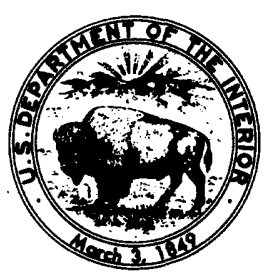




\section{DEPARTMENT OF THE INTERIOR}

DONALD PAUL HODEL, Secretary

U.S . GEOLOGICAL SURVEY

Dallas L. Peck, Director

For additional information write to:

District Chief

U.S. Geological Survey Water Resources Division 702 Post Office Building St. Paul, Minnesota 55101
Copies of this report can be purchased from:

U.S. Geological Survey Books and Open-File Reports Section Federal Center, Building 41 Box 25425

Denver, Colorado 80225 


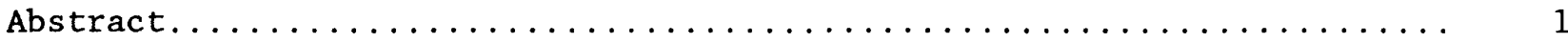

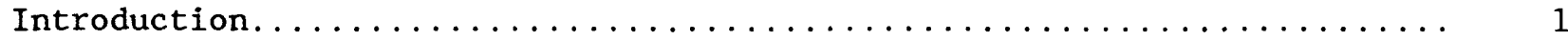

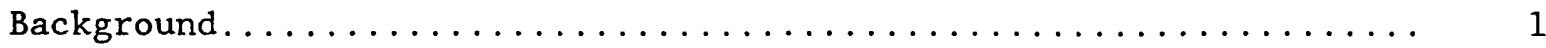

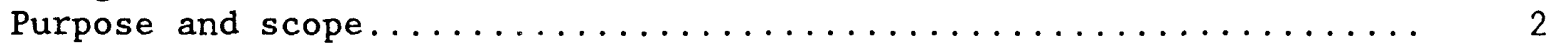

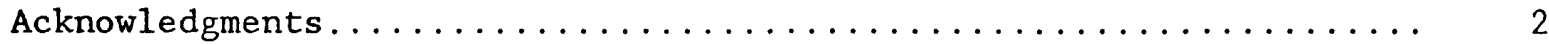

Description and interface of the Minnesota and National Water-Use Data

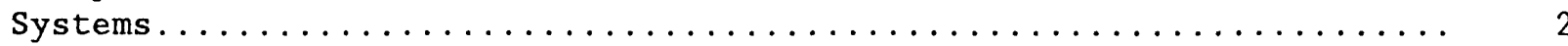

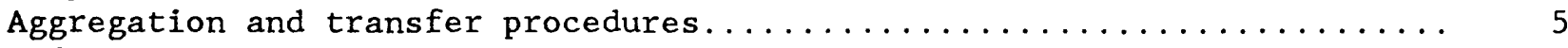

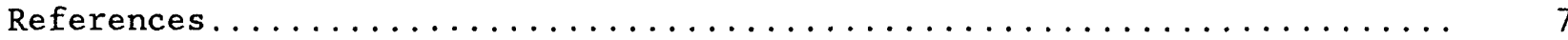

\section{ILLUSTRATIONS}

Figure 1. Map showing Minnesota Department of Natural Resources

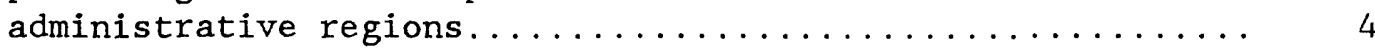

2. Example of final output form.....................6

\section{APPENDIXES}

Appendix A. U.S. Geological Survey format requirements annual rates

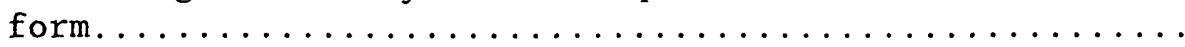

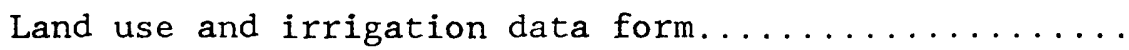

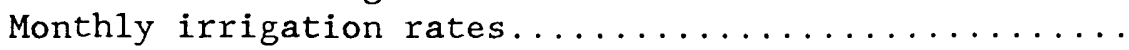
Water supplier/sewage treatment data form...........

B. Watershed and county aggregation report procedures for 1981, 1982, and 1983 water-use data

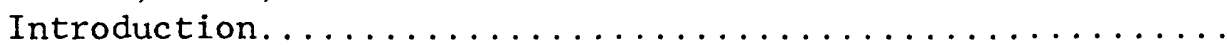

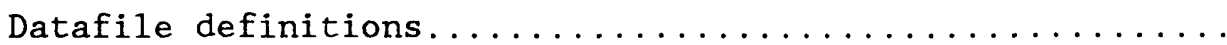

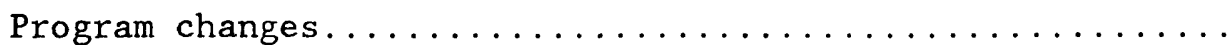

IBM-PC database structure....................

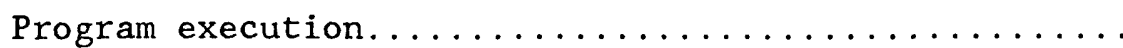

Executing statewide watershed programs.........

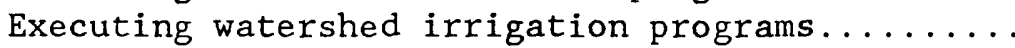

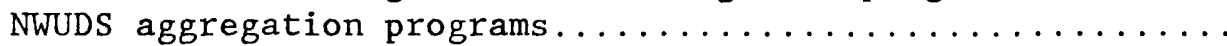

PG. programs

programs.

A -1

A -3

A -4

A -5

PG. FINAL

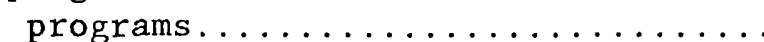

B -1

B -4

B- 5

B -6

B- 8

B-9

$\mathrm{B}-11$

$\mathrm{B}-12$

PG.REPORT

$\mathrm{B}-12$

$\mathrm{B}-13$

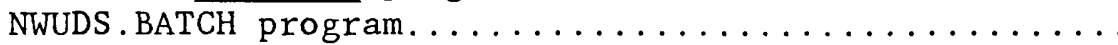

B -14

B -15

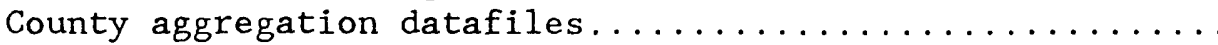

B -16

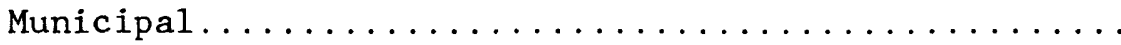

B -17

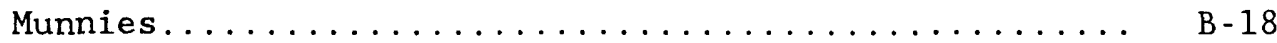

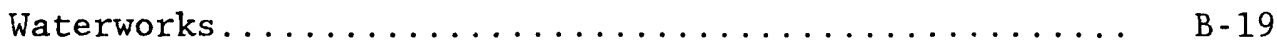

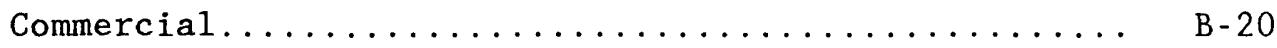

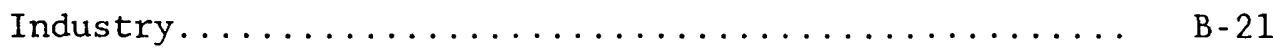

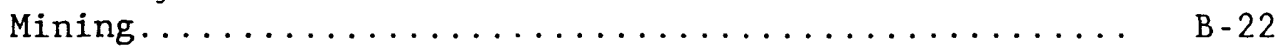

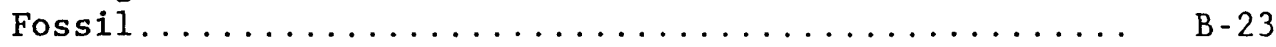

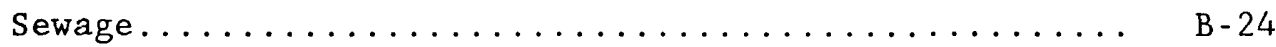

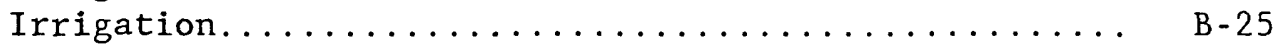

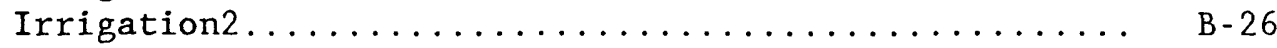

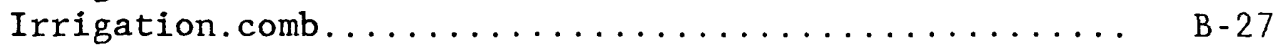

Domestic........................... B -28 
Appendix B. County aggregation programs.................. B-29

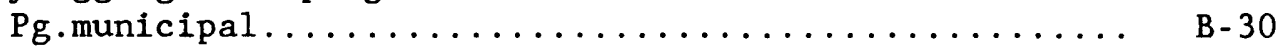

Pg.munnies..................... B-31

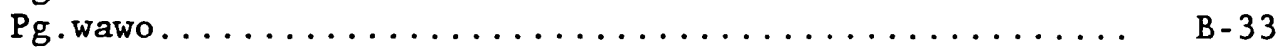

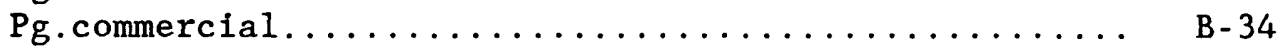

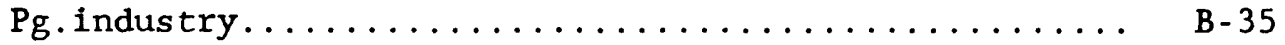

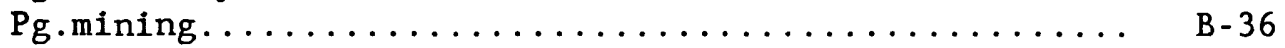

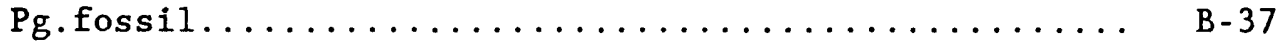

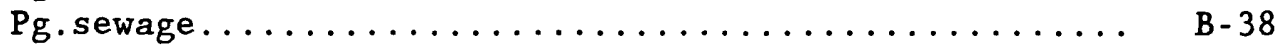

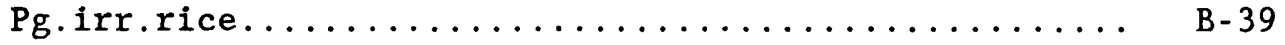

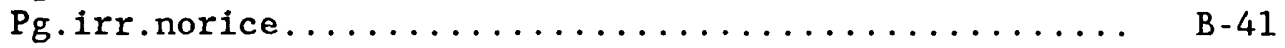

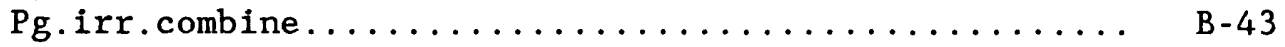

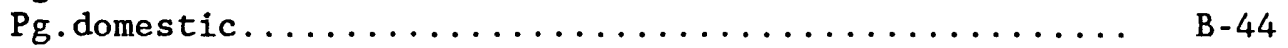

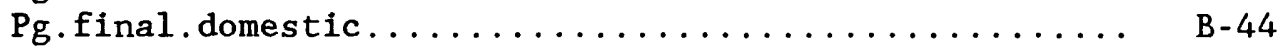

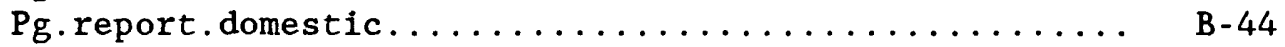

Watershed aggregation datafiles..................... B 45

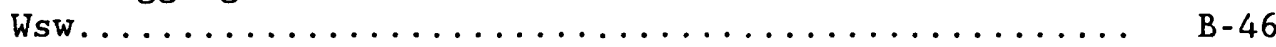

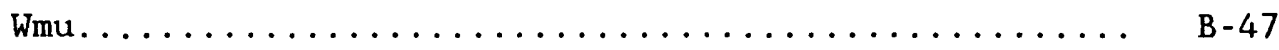

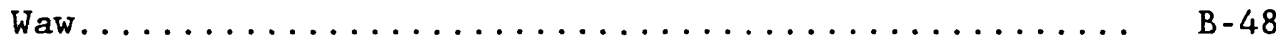

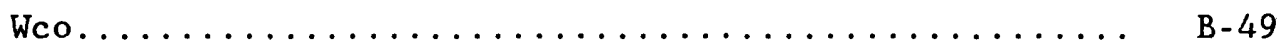

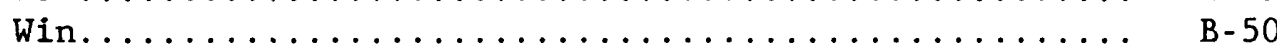

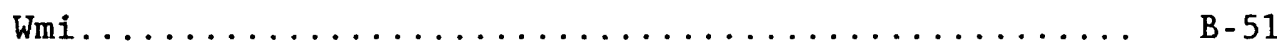

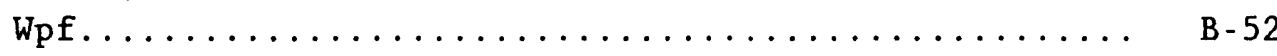

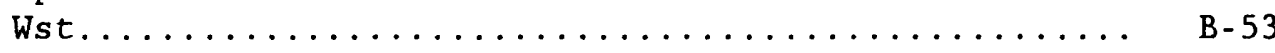

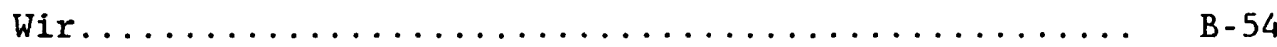

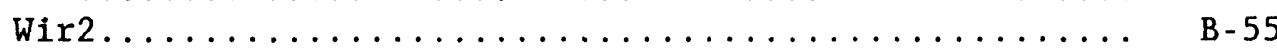

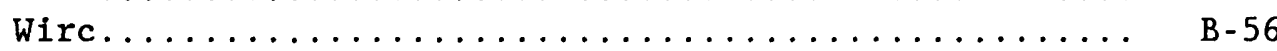

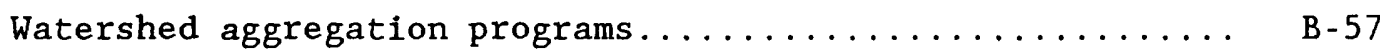

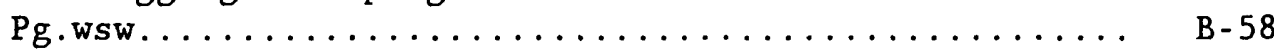

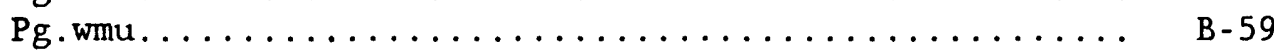

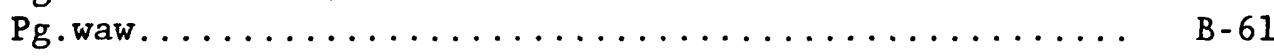

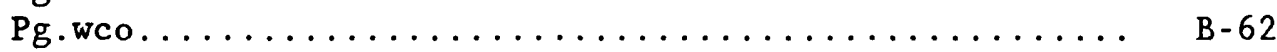

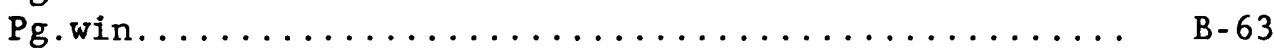

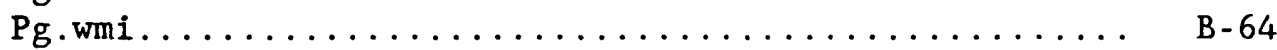

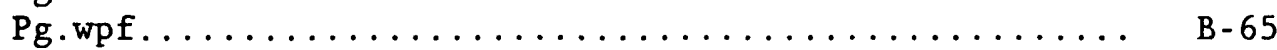

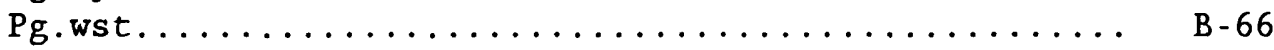

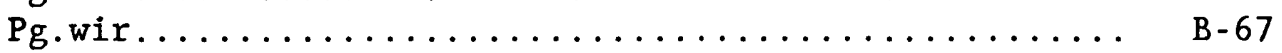

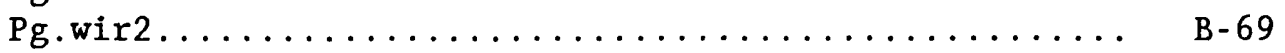

Pg.wirc..................... B 71 


\title{
AGGREGATION OF MINNESOTA WATER-USE DATA AND TRANSFER OF DATA TO THE NATIONAL WATER-USE DATA SYSTEM: PROCEDURES AND PROGRAMS
}

By L. C. Trotta

\begin{abstract}
The Minnesota Water-Use Data System stores data on the quantity of water withdrawals from ground-water and surface-water sources and discharge quantities reported annually for sites in Minnesota. To transfer these data into the U.S. Geological Survey's National Water-Use Data System properly, certain procedures must be followed. Uniform data categorization and entry allows comparison of water use from State to State. The data in the National Water-Use Data System are aggregated by county and by watershed (hydrologic unit). This report documents the data aggregation and transfer process as developed by the Minnesota Departent of Natural Resources, the Minnesota State Planning Agency/Plenning Information Center, and the U.S. Geological Survey as part of the National Water-Use Information Program.
\end{abstract}

\section{INTRODUCTION}

\section{Background}

The National Water-Use Information Program of the U.S. Geological Survey is a Federal-State cooperative program designed to collect, store, and disseminate water-use information both nationally and locally. The program was begun in 1978 to meet the need for a single source of uniform information on water use. The U.S. Geological Survey, Minnesota District, has been entering water-use data collected into a computerized data based called the National Water-Use Data System (NWUDS) since 1979. The data in NWUDS are aggregated by county and by watershed (hydrologic unit). Uniform data categorization and entry allows comparison of water use from State to State.

The Minnesota Water-Use Data System (MWUDS) stores data on the quantity of withdrawals from ground-water and surface-water sources and discharge quantities reported annually for sites in Minnesota. It further classifies this data for aggregation and trend analysis. The U.S. Geological Survey assisted the Minnesota Department of Natural Resources (MDNR) and the Land Management Information Center (now the Planning Information Center) in developing MWUDS in order to assure standardized State input to the National Water-Use Information Program. 


\section{Purpose and Scope}

This report describes how the MWUDS operates and how water-use data are aggregated and transferred to the NWUDS. This description of procedures supplements documentation written in 1984 by the Minnesota Land Management Information Center (now the Planning Information Center). This report supplies information about data processing not described elsewhere that might allow comparison of the MWUDS to another state water-use data system. Documentation here consists of a description of the how state and national data bases interface and an ordered set of procedures to aggregate and transfer data. Details of these procedures (including current hardware) will later be included in a U.S. Geological Survey procedures manual. Operations documentation for data-processing personnel will be incorporated into the procedures manual. Program documentation is being carried on separately from this report. User aids for the submission of data and management aids explaining applicability are not included here but represent worthy future goals for both Federal and State cooperating agencies.

\section{Acknowledgments}

The discussion of interface development is, for the most part, provided by Susanne Maeder of the Minnesota State Planning Agency/Planning Information Center (MSPA/PIC). Understanding of the aggregation procedures was developed as a result of training provided by Gina Miller of the MDNR, Division of Waters.

\section{DESCRIPTION AND INTERFACE OF THE MINNESOTA AND NATIONAL WATER-USE DATA SYSTEMS}

In Minnesota, an interface between data bases was developed by utilizing and improving existing locally devised programs for the aggregation and computer transfer of data from MWUDS data bases to the U.S. Geological Survey's NWUDS data base.

The MWUDS is based on the water-use records of the MDNR. The MDNR is charged with managing the appropriation of waters of the State (Minnesota Statutes, 105.41), and requires appropriation permits of all users appropriating more than 10,000 gallons per day or 1 million gallons per year. This permit authority essentially covers all but domestic users.

The development of MWUDS was a combined effort of MDNR, the MSPA/PIC, and the U.S. Geological Survey. Funding was provided, in part, by the U.S. Geological Survey as part of the National Water-Use Information Program. PIC was involved in data-base development. The MWUDS system is housed on both the Prime 850 minicomputer ${ }^{1}$ at PIC and on the IBM-PC microcomputer at MDNR, and uses the INFO data-base-management system developed by Henco, Inc., of Waltham, Massachusetts. The MDNR maintains the MWUDS system as part of its ongoing water-management responsibilities. 
The MWUDS is made up of six separate data bases which coincide with the six MDNR administrative regions (fig. 1). The data bases, SWDNR1 through SWDNR6, each contain water-use data for the counties within the respective region. Each of the regional data bases has the same design, and contains six main files with information on location, use type, resource used, and volume appropriated. Data items in MWUDS are described in Appendix A (Water-Use Data Base Description) of "Development of a Water-Use Data System in Minnesota" (Horn, 1986). Further information on MWUDS (locally called the State Water-Use Data System) is provided in the "State Water-Use Data System (SWUDS) System Documentation," (Land Management Information Center, 1984).

The NWUDS is housed on a computer at U.S. Geological Survey national headquarters in Reston, Virginia. NWUDS contains the following categories of water-use data:

agriculture/1ivesotck
commercia1
domestic
industrial
irrigation
mining

water supply
sewage treatment
power-fossil
power-nuclear
power-hydro
power-geothermal

PIC developed computer programs to collect and combine individual permit data and arrange it in acceptable NWUDS entry format for each of the first nine of these categories. Because there are only two nuclear plants in the State, this information is generated manually by the U.S. Geological Survey. Currently, hydropower appropriations are not adequately represented on the State Water-Use Data System. In 1980, the U.S. Geological Survey aggregated hydropower data manua11y, using data obtained from the Minnesota Department of Energy and Economic Development. There is no geothermal water use in Minnesota.

Data-aggregation formats follow the U.S. Geological Survey requirements as specified in Appendix A. The final output form for transmission to the NWUDS is as shown in figure 2. PIC developed computer programs to collect and combine annual water use by county and by watershed (hydrologic unit).

The hydrologic-unit aggregation program is similar to the county aggregation program in form. Although each county's data is located entirely in one of the six regional data bases, data from an individual hydrologic unit may be located in more than one of the data bases because hydrologic units do not follow county or administrative-region boundaries. Therefore, the job programs described in Appendix B accumulate each county's information from just one of the regional data bases, but accumulate hydrologic-unit totals across data-base lines. The hydrologic-unit job programs must access each of the six regional data bases sequentially and accumulate data into the appropriate hydrologic unit.

1 Use of trade names in this report is for identification purposes only and does not constitute endorsement by the U.S. Geological Survey. 


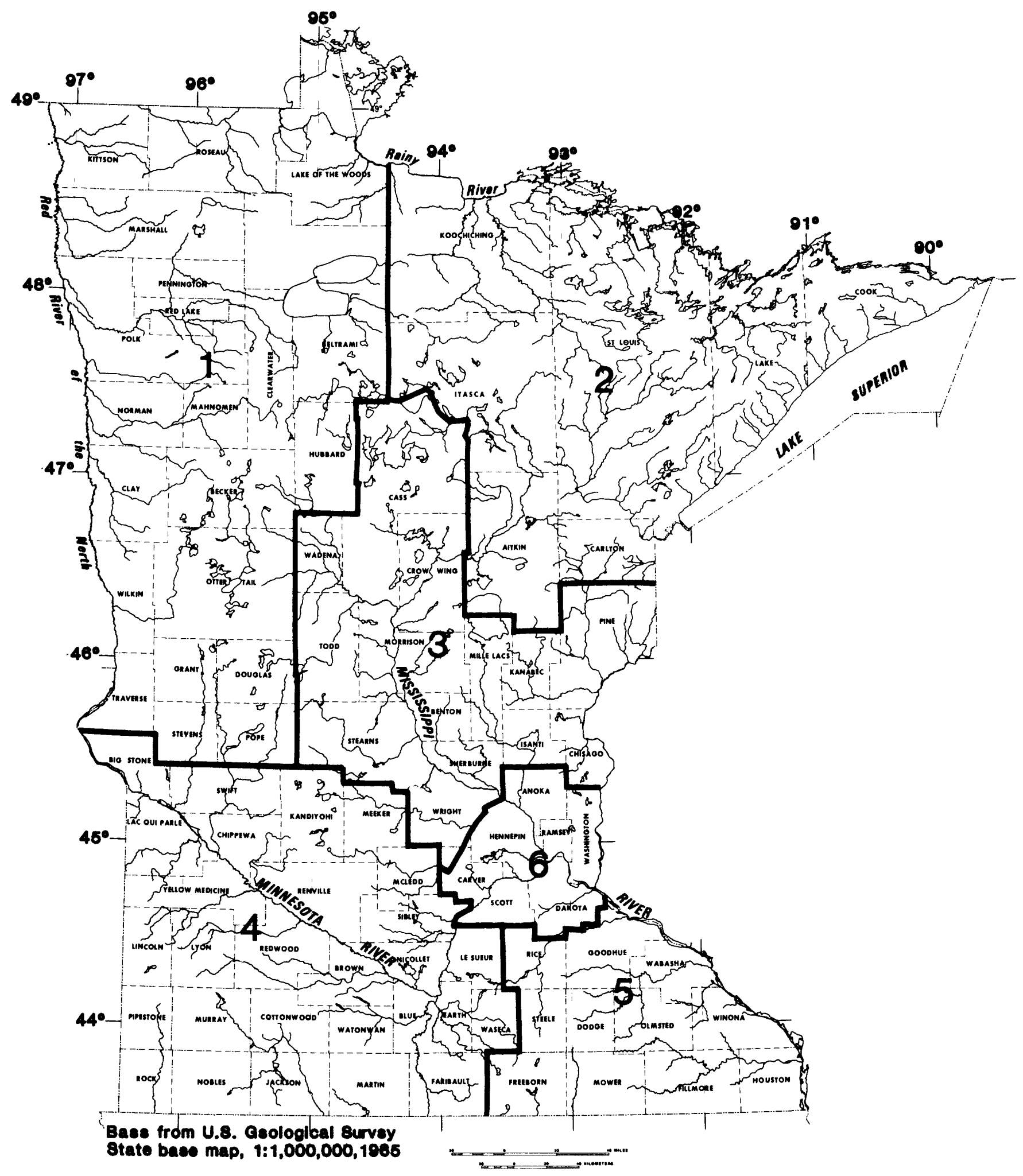

Figure 1.--Minnesota Department of Natural Resources Administrative Reglons. 


\section{AGGREGATION AND TRANSFER PROCEDURES}

The aggregation procedures described herein are an overview of the hierarchy of operations that now make it possible to bring disparate individual water-use-report data in the MWUDS into proper format for submission to the U.S. Geological Survey, Minnesota District. Although the U.S. Geological Survey water-use representative assisted with these procedures for training purposes in 1985, the procedures usually are excuted by MDNR personnel. Data files and aggregation programs for transfer of MWUDS data to NWUDS are described in the "United States Geological Survey National Water-Use Data System (NWUDS) Watershed and County Aggregation Report, Procedures for 1981, 1982, and 1983 Water-Use Data," included here as Appendix B.

Specific hardware and software to execute the aggregation and transfer procedures are not given in this report in an attempt to keep the description of procedures generic. With changes in either hardware or software, new procedures may be required in the future.

Aggregation procedures may commence whenever all permit-report data for a given year has been entered into MWUDS (usually in the fall of the year following the year of data). To begin, the year of MWUDS data in computer storage is verified by checking ground-water and surface-water totals against previously compiled totals region by region. Discrepancies are compared to changes in number of inventory points for justification or corrective action. Using INFO commands, necessary corrections are made by matching permit numbers and removing duplicates. When verification is finished, INFO datafiles are prepared for each county and later for each hydrologic unit. Each of the six regional MDNR water-use data bases are then accessed and the aggregation programs appropriate to each data file are run. This fills the data files with water-use totals. Consecutively run programs convert the units to million gallons per day and add information required by NWUDS format such as the Federal identification numbers for State and county (see Appendix A). A status sheet is updated to keep track of which data files have had all aggregational programs run. When the county data aggregations have been completed, output files are checked for possible program errors. Program changes or cosmetic modifications to output files may be made at this point. If no program changes are necessary, aggregated data are loaded on diskettes, backups are made, and the data diskettes are delivered to the U.S. Geological Survey water-use representative in the Minnesota District office. The process is then repeated for hydrologic-unit (watershed) data aggregations.

Once the MWUDS data have been aggregated, the job of the water-use representative is to be sure the data pass NWUDS edit routines and then to update the proper NWUDS data base. At present (1986), update involves electronic file transfer on the Minnesota District's Prime 750 minicomputer. 


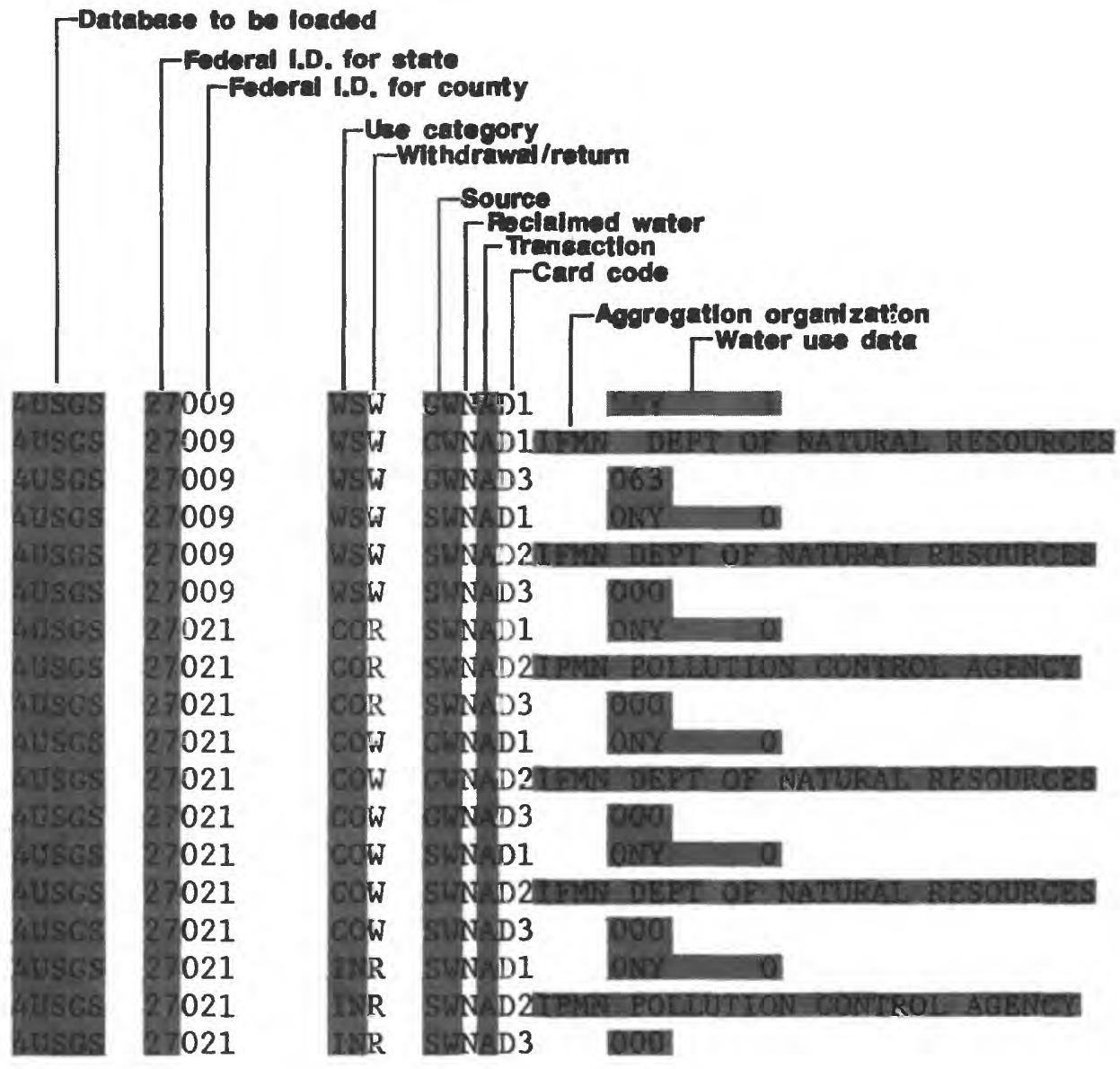

Figure 2.--Example of Final Output Form 


\section{REFERENCES}

Horn, M. A., 1986, Development of a Water-Use System in Minnesota: U.S. Geological Survey Water-Resources Investigations Report 85-4306, 59 p.

Minnesota Land Management Information Center, 1984, State Water-Use Data System (SWUDS) System Documentation: Minnesota State Planning Agency, St. Paul, $42 \mathrm{p}$. 
APPENDIX A

U.S. GEOLOGICAL SURVEY FORMAT REQUIREMENTS 
YEAR :

U.S. GEOLOGICAL SURVEY

WATER RESOURCES DIVISION

DATE :

NATIONAL WATER-USE DATA SYSTEM AGGREGATED DATA BASE

RECORDED BY:

ANNUALRATESTORM
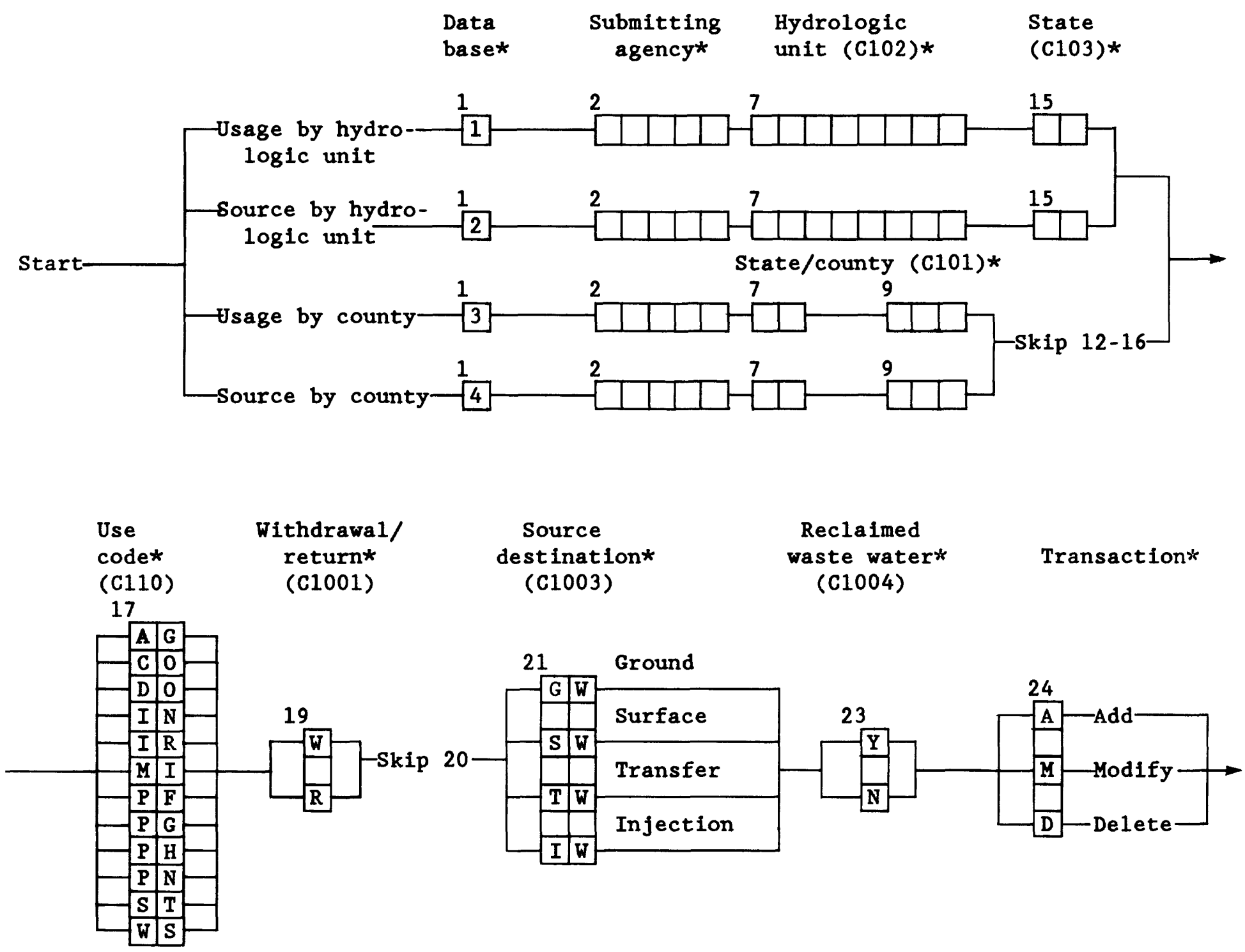

Card

Annual rate - fresh

Annual rate - saline

Annual rate -

code*

$(\leq 1000 \mathrm{mg} / 1)(\mathrm{C} 1020)$

$(\geq 1000 \mathrm{mg} / 1)(\mathrm{C} 1021)$

unknow quality (C1022)

25

$25 \quad 27$

34

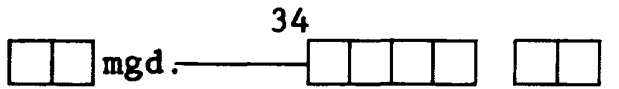

mgd

41 


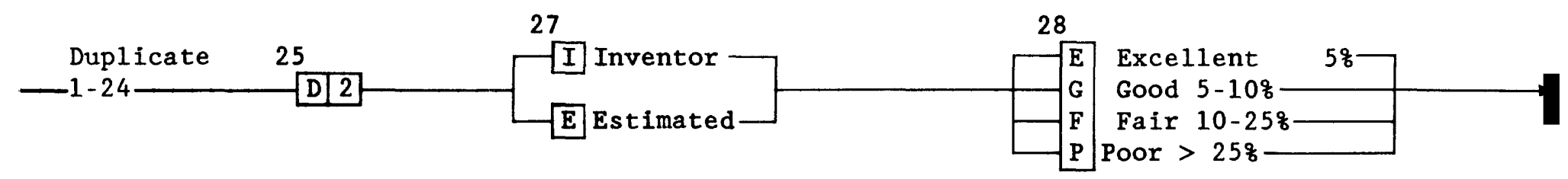

Aggregation organization 29

- code and name (C1010) - पl|l|l|l

49

34

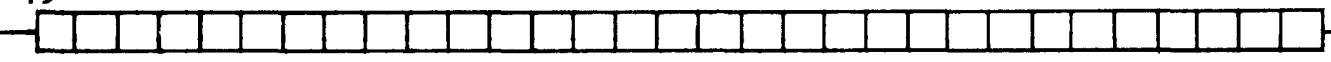

AGGREGATION INFORMATION (continued)

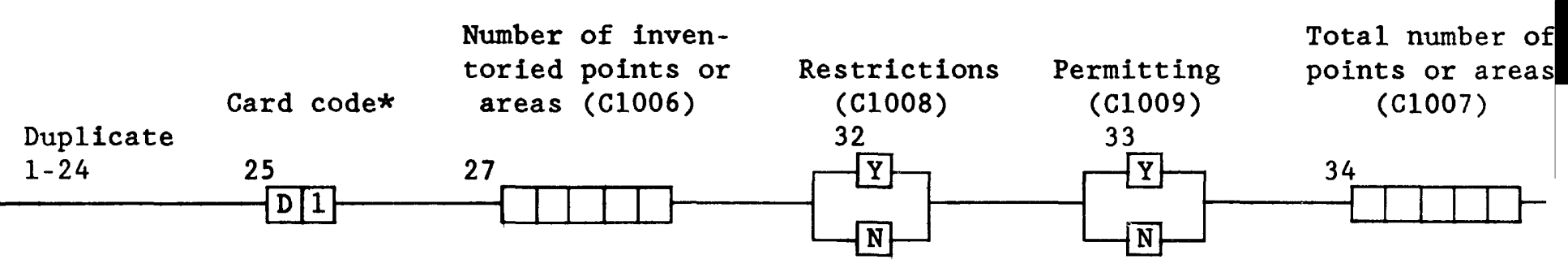

\section{FACILITIES TREATING WATER}

(Duplicate columns 1-24)

Total

number

\section{facilities}

Card treating

code* fresh water (C1401) $25 \quad 27$

\begin{tabular}{|l|l|l|l|l|}
\hline $\mathrm{L}$ & 1 \\
\hline
\end{tabular}

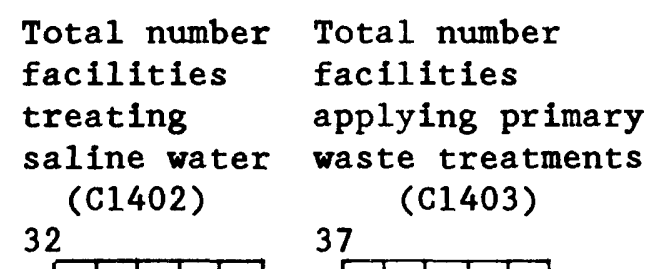

Total number Total number facilities facilities treating saline water (C1402) 32 applying primary waste treatments (C1403)

37

Total number facilities applying secondary waste treatments (C1404)

42

Total number facilities applying tertiary waste treatments (C1405)
47
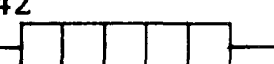
The comments on the Nl cards apply to the data reported about the specific withdrawals or return information identified by the data on the front of this form.

Card Code*

Comment (C1902)

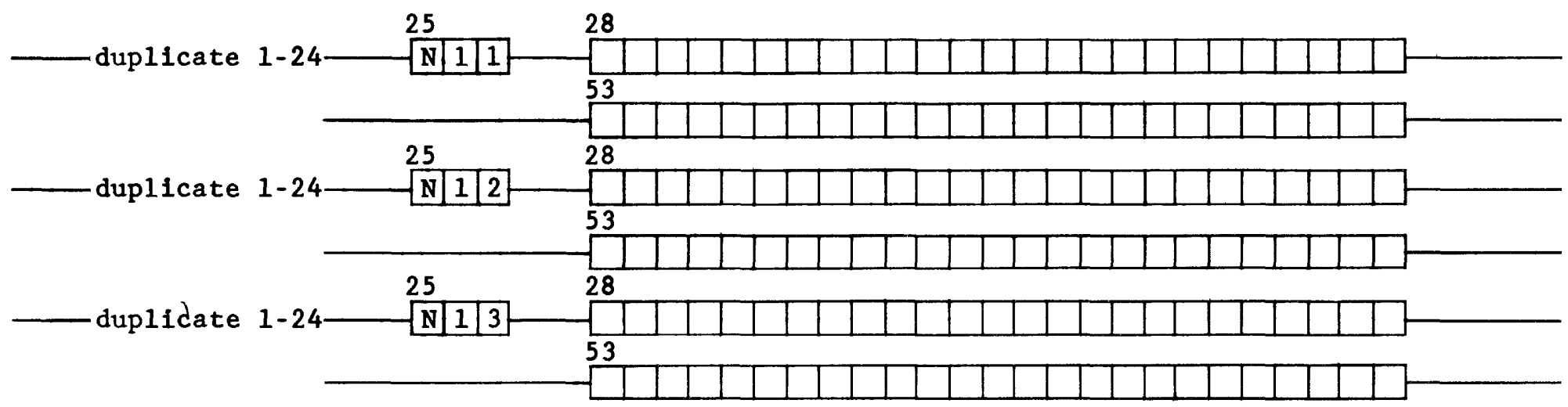


U.S. GEOLOGICAL SURVEY

WATER RESOURCES DIVISION

YEAR :

DATE:

NATIONAL WATER-USE DATA SYSTEM AGGREGATED DATA BASE

RECORDED BY:

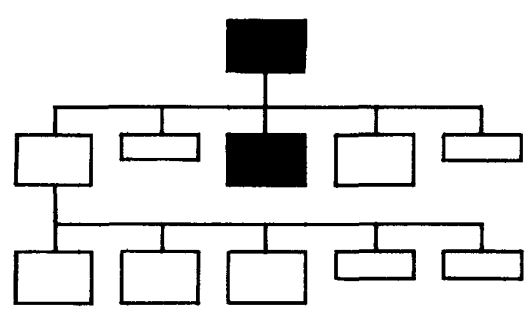

LAND USE AND IRRIGATION DATA FORM

$\begin{array}{lcll}\text { Data } & \text { Submitting } & \text { Hydrologic } & \text { State } \\ \text { base* } & \text { agency* } & \text { unit }(\mathrm{C012}) * & (\mathrm{C103}) *\end{array}$

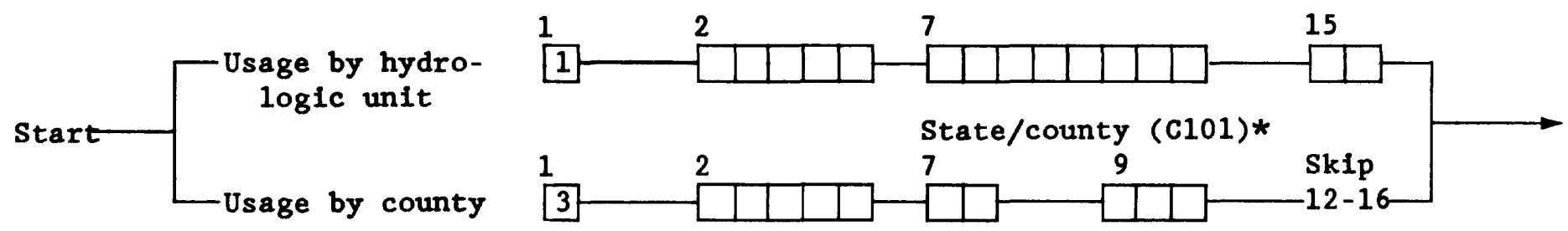

Use code*

Transaction*

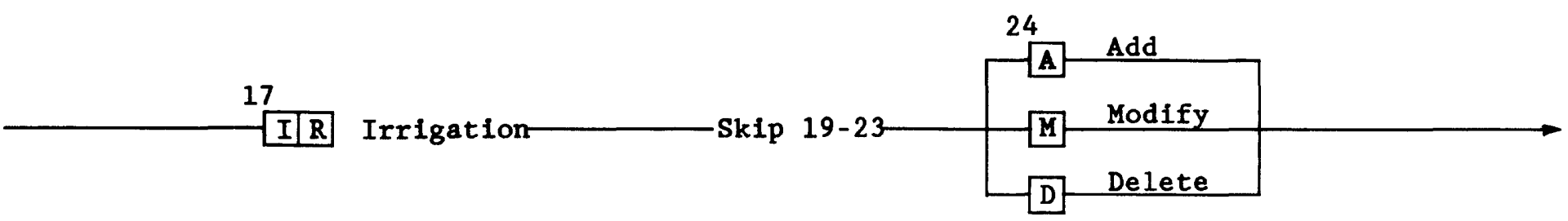

Card code* Land use type (C2501)*

27

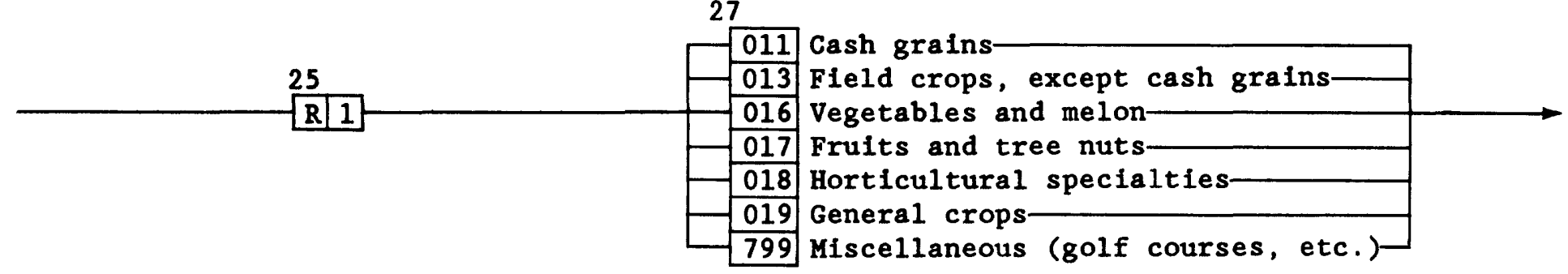

Total acres

irrigated (C2502)

Annual rate

30

37 
Card code* Land use type (C2501)*

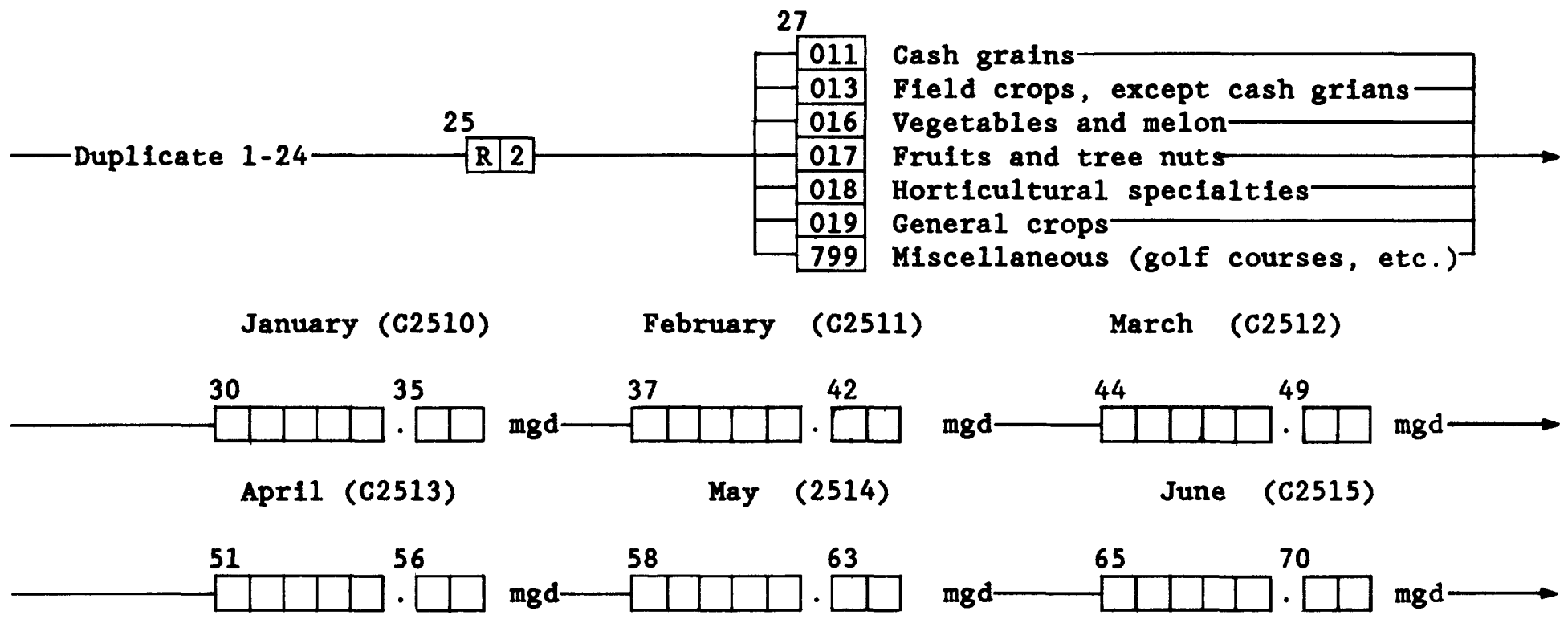

MONTHLY IRRIGATION RATES (continued)

Card code* Land use type (C2501)*

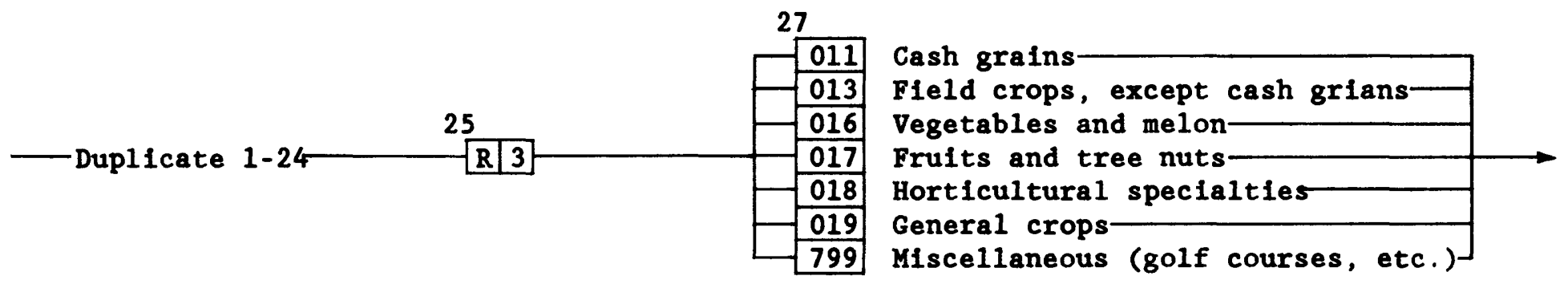

July (C2516)

$30 \quad 35$

October (C2519)

51

56
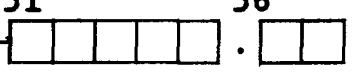

August (C2517)

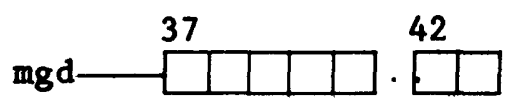

November (2520)

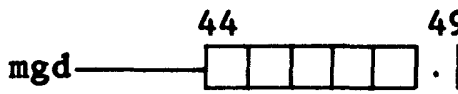

49 $\square \mathrm{mgd}$

December (C2521)

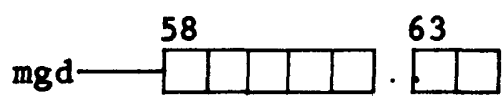

mgd

65

70

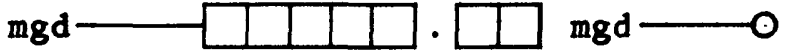


YEAR :

U.S. GEOLOGICAL SURVEY

WATER RESOURCES DIVISION

DATE :

NATIONAL WATER-USE DATA SYSTEM AGGREGATED DATA BASE

RECORDED BY :

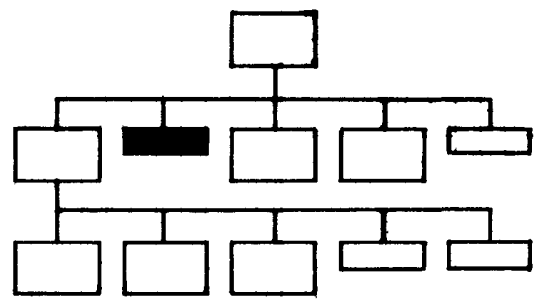

WA TER SUPPLIER/SEWAGE TREATMENT DATA FORM

$\begin{array}{lcll}\text { Data } & \text { Submitting } & \text { Hydrologic } & \text { State } \\ \text { base* } & \text { agency* } & \text { unit }(\mathrm{CO12}) * & (\mathrm{ClO3}) *\end{array}$

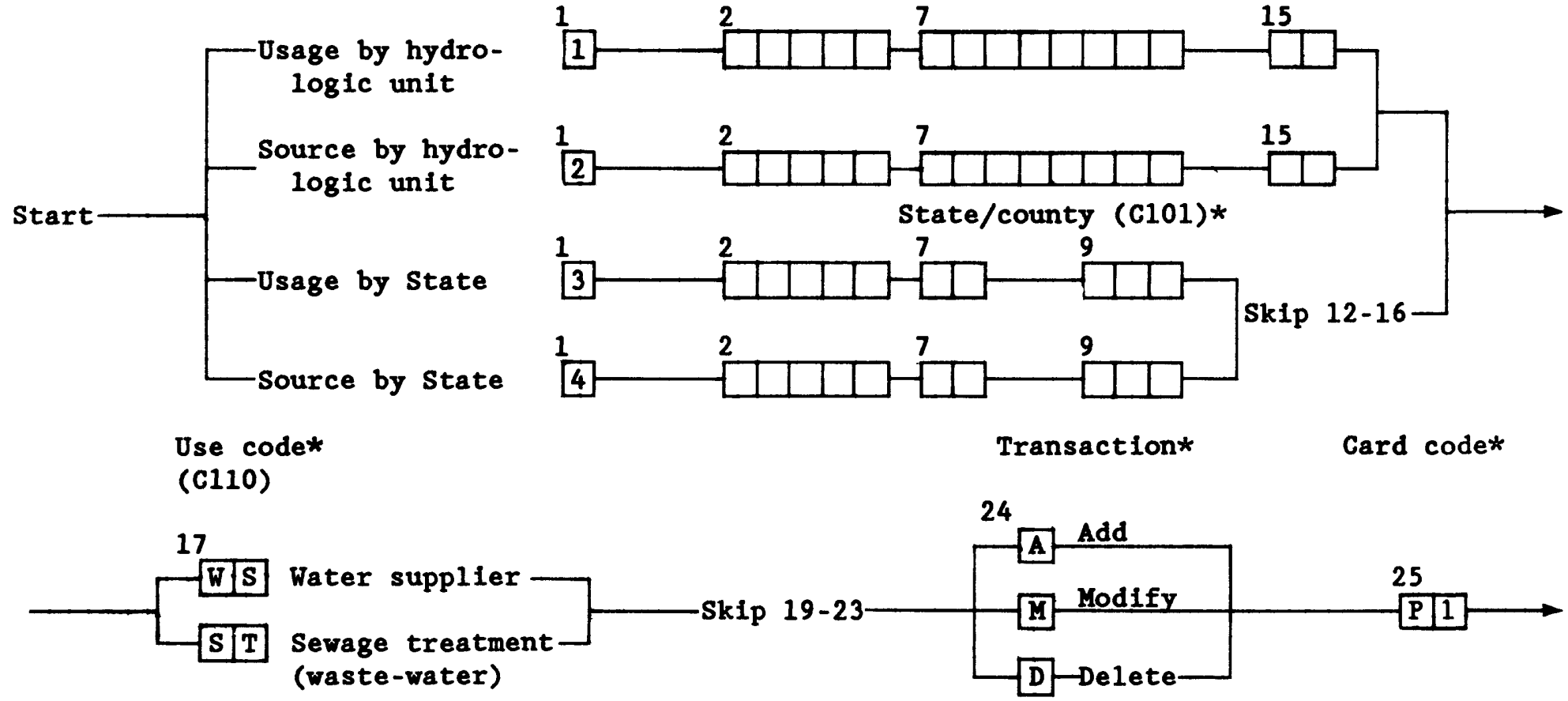

Keypunching instructions: Omit cards which do not contain population data (C2002, C2003)

Functional use*

(C2001)

27

AG

Agriculture

-Duplicate 1-26-CO Commercial

-Dup1icate 1-26 DO Domestic

-Duplicate 1-26 IN Industrial

-Duplicate 1-26-IR Irrigation

-Duplicate 1-26-MI Mining

-Duplicate 1-26-PO Power No. of people served (C2002) domestic only Skip 29-35 Skip 29-35

29 Skip 29-35

Skip 29-35

Skip 29-35

Skip 29-35
No. of connections served (C2003)

36

-Duplicate 1-26 WS Water Supplier

$\longrightarrow$ \begin{tabular}{l|l|l|l|l}
$\square$ & & & &
\end{tabular}
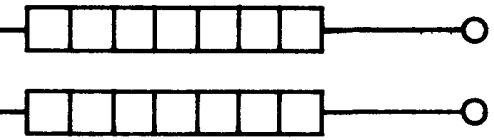

Skip 29-35 
APPENDIX B

WATERSHED AND COUNTY AGGREGATION REPORT

PROCEDURES FOR 1981, 1982, AND 1983 WATER-USE DATA 


\section{U.S. GEOLOGICAL SURVEY \\ NATIONAL WATER-USE DATA SYSTEM \\ WATERSHED AND COUNTY WATER-USE AGGREGATION \\ PROCEDURES FOR 1981, 1982, AND 1983 DATA}

\section{INTRODUCTION}

The following documentation refers to changes and modifications to the U.S. Geological Survey (USGS), National Water-Use Data System (NWUDS) Aggregation Programs. The aggregation programs for 1980 water-use data were developed by the Land Management Information Center (LMIC). Refer to the file NWUDSS.DOCUMENTATION for procedures and programs used to generate 1980 aggregation reports.

Water-use aggregation programs for report years 1981, 1982, 1983 were run on an IBM PC-XT using PC-INFO software developed by Henco. Three data files from the Minnesota Department of Natural Resources (MDNR), State Water-Use Data System (SWUDS) were downloaded using "Kermit" transfer utility to the PC. The regional datafiles transferred to the $\mathrm{PC}$ include:

COMMON.FILE - contains specific use type, and resource information required for the aggregation reports.

REPORTED.PUMPAGE - contains the annual volumes of water appropriated and discharged.

WATER.USE.PERM - contains the permitted acreage and permitted appropriation volume for each MDNR permit holder. This data is required for running the irrigation aggregation programs.

Listed below are use-type datafiles created to store annual water-use data:

County datafiles

SWUDS use codes

Watershed datafiles

MUNICIPAL

use codes $10-16$

WSW

MUNNIES

use code 11

WMU

WATERWORKS

use codes $10,12-16$

WAW

COMMERCIAL

use codes $30-35$

WCO

INDUSTRY

use codes $41,42,46$,

WIN

47,48

MINING

use codes $62,63,64$,

WMI

$$
43,44
$$




\begin{tabular}{lcc}
\hline County datafiles & SWUDS use codes & Watershed datafiles \\
\hline FOSSIL & $\begin{array}{c}\text { use codes } 20,22,23 \\
24,25\end{array}$ & WPF \\
IRRIGATION & use code 96 & WIR \\
IRRIGATION2 & use codes $80-90$ & WIR2 \\
IRRIGATION.COMB & use codes $80-96$ & WIRC \\
DOMESTIC & county population \\
census data & use code 45 & WST \\
SEWAGE &
\end{tabular}

Specific use types are identified below under each use-type datafile:

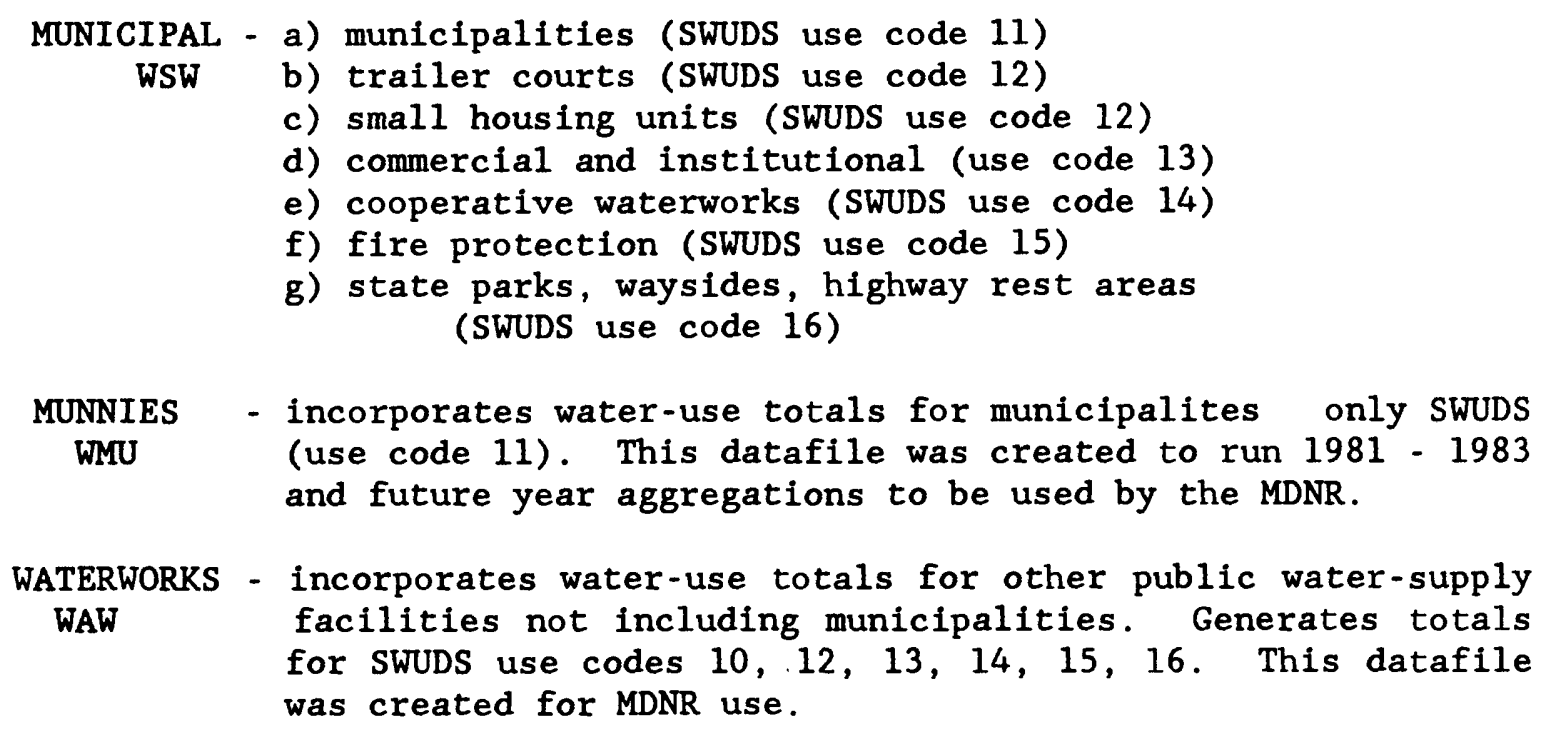

Note: MUNNIES data + WATERWORKS data combined equals the data incorporated in the MUNICIPAL datafile. 


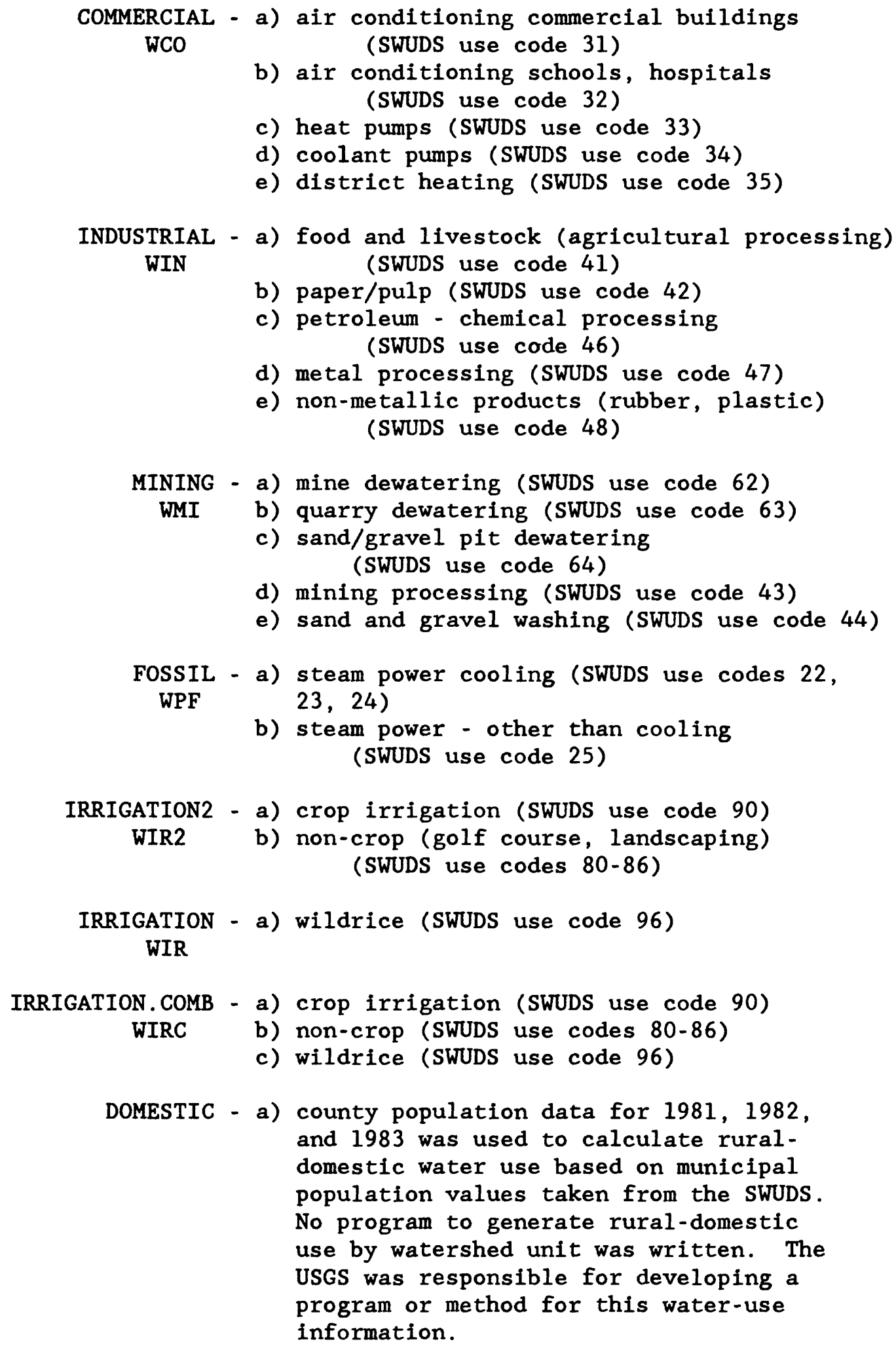




\section{DATAFILE DEFINITIONS}

Data item names follow this basic structure:

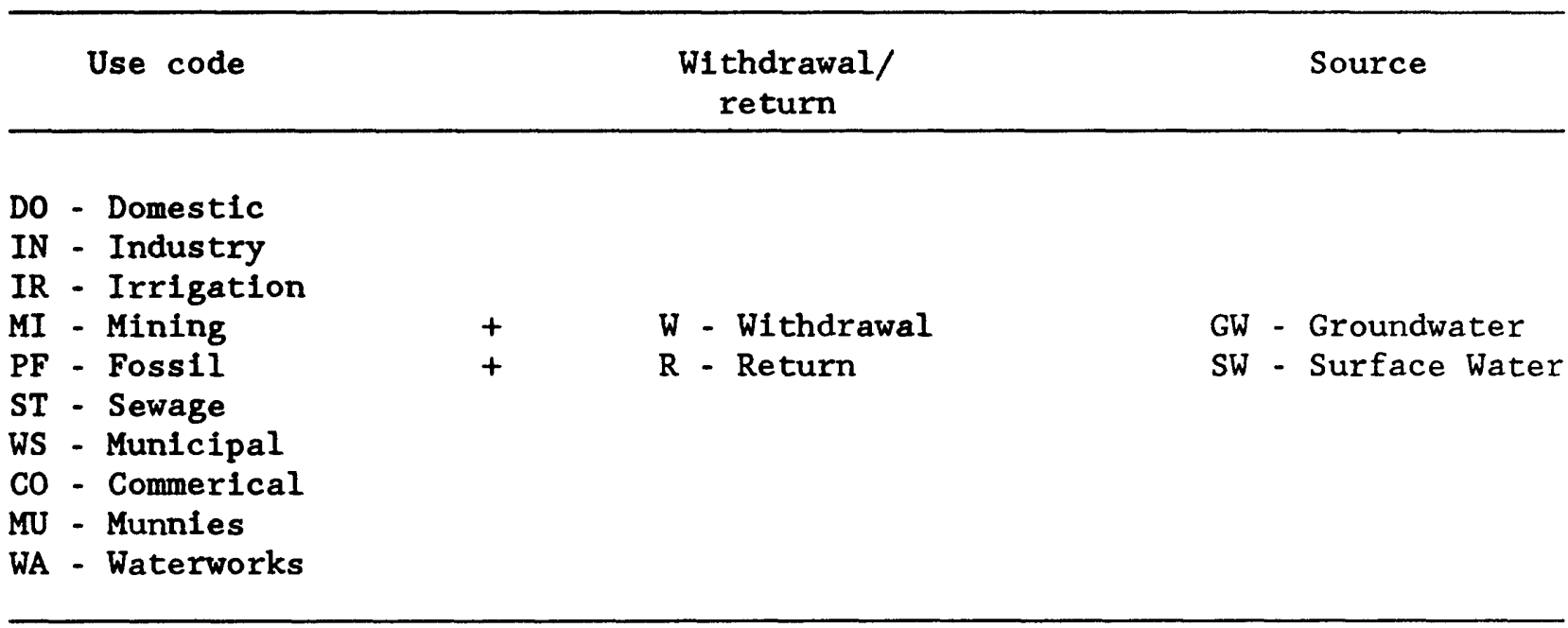

Example: Data items for the municipal datafile are listed below.

WSW.GWNAD3 - total ground water withdrawal (reported and estimated)

WSW.GWNAD2 - agency source for ground water withdrawal (MDNR)

WSW.GWNADI - total reported ground water source points (number of ground water installations)

WSW.GWNY - total reported and estimated ground water source points

WSW.SWNAD3 - total surface water withdrawal (reported and estimated)

WSW.SWNAD2 - agency source for surface water withdrawal data (MDNR)

WSW.GWNADI - total reported surface water source points

WSW.SWNY - total reported and estimated surface water source points

WSW.GWRV - total reported ground water withdrawal

WSW.SWRV - total reported surface water withdrawal

WSW.GWEI - total ground water estimated source points

WSW.SWEI - total surface water estimated source points

Note: Municipal discharge values are calculated and incorporated under the sewage treatment data item STR.SWNAD3. A11 discharge volumes and number of dischargers are entered as an estimate. 


\section{PROGRAM CHANGES}

Programs to aggregate data on the above use-type categories all follow the same general format (see page B-4). Modifications to the 1980 NWUDS Programs are as follows :

1) MDNR appropriators who did not report their annual water use or who were not required to report (due to termination or they reported water use from another installation under the same permit) were not included in the number of source withdrawal points. They were incorporated in the 1980 aggregation reports. The command in each program to eliminate nonappropriation source points reads as follows:

RES FOR MEAS.ACC LT 6 OR MEAS.ACC GT 7

2) Three new data items were defined to separate estimated water use from reported water use (both SW \& GW) and estimated installations from reported installations.

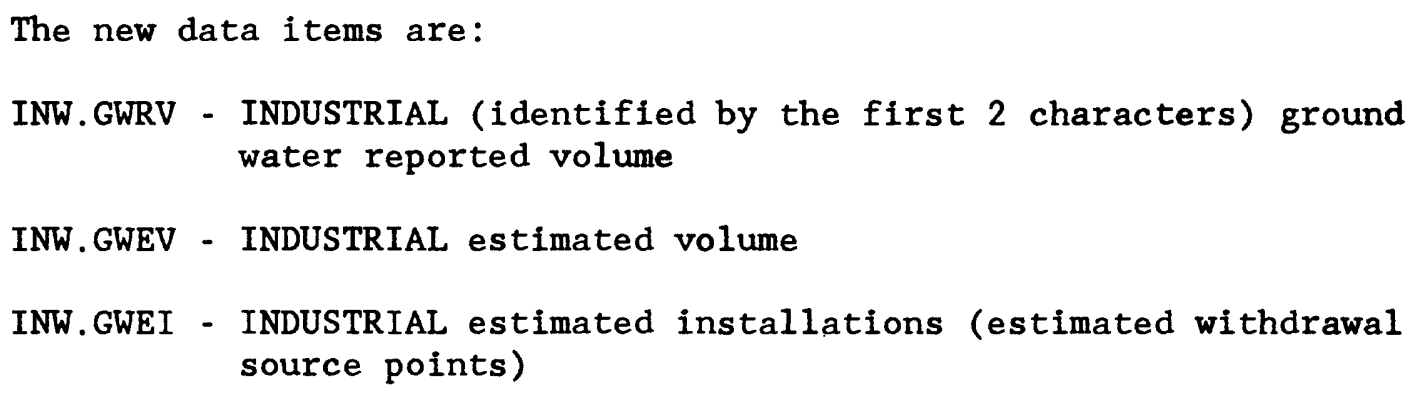

3) Use Code 44 (sand and gravel washing) was incorporated into the MINING program. The 1980 INDUSTRIAL aggregation program included use code 44 .

4) The PG.MINING program now incorporates use codes 43, 44, 62, 63, and 64 . The PG.MINING program for 1980 water use only included use code 43 (taconite mining and processing).

5) Four new datafiles were created, MUNNIES and WATERWORKS for county aggregations and WMU and WAW for watershed aggregations. The MDNR felt it necessary for in-house analysis of water use to separate municipal water appropriation from other public supply facilities. These data aggregations are supplied for NWUDS requirements in the municipal datafile.

6) In the program PG.MUNNIES, population served, as well as service connections within a municipality, are calculated for surface-water users and ground-water users separately. However, NWUDS requires one combined ground and surface water total for each of these data fields (data items; POP.SERVE and SERVICE.CONN). 


\section{IBM-PC DATABASE STRUCTURE}

Three SWUDS datafiles for each region were transferred from the Prime to the IBM-PC. Datafile definitions, and the actual data were transferred separately (using kermit transfer utility). This procedure was preferred over the INFOSYS \XFER transfer utility which transfers the data and the datafile definition simultaneously and loads one record at a time onto the PC using the COMINPUT COMMAND (very slow process!). Therefore, data was transferred in a compressed file format, and empty datafile definitions were transferred in a separate file transfer process.

The 1980 NWUDS programs, and datafile definitions were transferred from the prime to the PC using the INFOSYS \XFER transfer utility. This transfer utility downloads everything which resides on the specified directory pathname. Therefore, all programs and datafiles were transferred in one application. If KERMIT had been used, each program and datafile would have to be named for the transfer process.

For county aggregations, 18 regional databases were created on the IBM-PC (6 regions times 3 years pumpage data). The databases are listed below:

\begin{tabular}{|c|c|c|}
\hline Region & Year & $\begin{array}{c}\text { Database } \\
\text { (user-name) }\end{array}$ \\
\hline 1 & 81 & NW1 \\
\hline 1 & 82 & $\mathrm{~N} 12$ \\
\hline 1 & 83 & N13 \\
\hline 2 & 81 & NUD \\
\hline 2 & 82 & NU2 \\
\hline 2 & 83 & N23 \\
\hline 3 & 81 & NW3 \\
\hline 3 & 82 & N32 \\
\hline 3 & 83 & N33 \\
\hline 4 & 81 & NW4 \\
\hline 4 & 82 & $\mathrm{~N} 42$ \\
\hline 4 & 83 & N43 \\
\hline 5 & 81 & NW5 \\
\hline 5 & 82 & N52 \\
\hline 5 & 83 & N53 \\
\hline 6 & 81 & NW6 \\
\hline 6 & 82 & N62 \\
\hline 6 & 83 & N63 \\
\hline
\end{tabular}


Three statewide county aggregation databases were stored on diskettes to consolidate regional water-use data. The database names are:

C81 - contains 1981 county water-use totals by use type.

C82 - contains 1982 county water-use totals by use type.

C83 - contains 1983 county water-use totals by use type.

An INFO database is created on the PC at the 'ENTER USER-NAME>' prompt, an asterisk (*) followed by a three-digit alphanumeric code creates a new database. All internal file names can be referenced to the user-name.

Once a regional database has been created, and the NWUDS programs and datafile definitions loaded, subsequent regional databases created can copy all required programs and datafile definitions from the initial database by using the following command:

ENTER COMMAND> TAKE FROM USER-NAME * (copies everything associated with that user-name)

Programs, whicl have been copied from one INFO user to another using the TAKE command, must be modified to reflect the correct year, and output filename.

For watershed aggregations three statewide databases were created:

\begin{tabular}{cc}
\hline Year & $\begin{array}{c}\text { Database } \\
\text { (user-name) }\end{array}$ \\
\hline 1981 & WTS \\
1982 & W82 \\
1983 & W83 \\
\hline
\end{tabular}

Statewide databases were developed rather than regional databases because watershed boundaries do cross county boundaries (each county is located entirely in one of the MDNR's six regional databases).

Although water-use volumes by watershed unit were aggregated statewide, the irrigation program PG.WIR, and PG.WIR2 cannot accumulate totals in their respective statewide datafiles because these programs calculate estimated water use and acres irrigated based on county permitted values. Refer to the program execution section for running watershed irrigation programs. 
To load county or watershed numbers into each specific use-type datafile definition, two DOS files were created:

WAT.SAM - contains 81 major watershed numbers, and the associated USGS watershed number

CTY.SAM - contains the 87 county numbers

Note : The DOS files must have the suffix of ".SAM " to access the DOS file in a sequential manner. (compressed mode)

Example: enter command> SEL MUNICIPAL

0 records selected

enter command> GET CTY.SAM COPY

87 records selected

\section{Program Execution}

The 1981 county database information on floppy diskettes for each region contain the data for the COMMON.FILE, WATER.USE.PERM, and REPORTED.PUMPAGE datafiles. Because of the time involved in restoring and backing up files on the IBM PC-XT, and to enable statewide watershed aggregation reports to be run, these SWUDS datafiles were externaled when running 1982 and 1983 county aggregations, as well as, 1981,1982 , and 1983 watershed aggregation programs. Refer to the PC-INFO users manual for procedures in externaling INFO datafiles.

The DOS file names which created the external associations to the specific regional datafiles are listed below:

\begin{tabular}{lcc}
\hline Region & Datafile & $\begin{array}{c}\text { Dos file name } \\
\text { (info internal name) }\end{array}$ \\
\hline 1 & COMMON.FILE & NW1000.DAT \\
1 & WATER.USE.PERM & NW1001.DAT \\
1 & REPORTED.PUMPAGE & NW1002.DAT \\
2 & COMMON.FILE & NUD034.DAT \\
2 & WATER.USE.PERM & NUD035.DAT \\
2 & REPORTED.PUMPAGE & NUD033.DAT \\
3 & COMMON.FILE & NW3000.DAT \\
3 & WATER.USE.PERM & NW3001.DAT \\
3 & REPORTED.PUMPAGE & NW3002.DAT \\
4 & COMMON.FILE & NW4000.DAT \\
4 & WATER.USE. PERM & NW4001.DAT \\
4 & REPORTED.PUMPAGE & NW4002.DAT
\end{tabular}




\begin{tabular}{lcc}
\hline Region & Datafile & $\begin{array}{c}\text { Dos file name } \\
\text { (info internal name) }\end{array}$ \\
\hline 5 & COMMON.FILE & NW5000.DAT \\
5 & WATER.USE.PERM & NW5002.DAT \\
5 & REPORTED.PUMPAGE & NW5001.DAT \\
6 & COMMON.FILE & NW6000.DAT \\
6 & WATER.USE.PERM & NW6002.DAT \\
6 & REPORTED.PUMPAGE & NW6001.DAT \\
\hline
\end{tabular}

\section{Executing Statewide Watershed Programs}

When executing the statewide watershed programs, a batch job procedure was developed. One statewide datafile is associated with each USE CATEGORY (11 use-type datafiles for each year).

The DOS batch file job directs PC-INFO to begin an INFO session by reading the INFO user name and subsequent INFO commands from a COMINPUT file. The first record in the COMINPUT file must be the INFO user-name. Refer to the IBM-DOS manual to create a batch file.

EXAMPLE:

DOS BATCH FILENAME: RUN.BAT (all batch files must have the file extension .BAT)

$\begin{array}{lll}\text { BATCH COMMANDS } & : & \text { ECHO OFF } \\ & : & \text { ECHO PLACE INFO KEY-DISK IN UNIT A } \\ \text { COMINPUT FILE } & \vdots & \text { PAUSE } \\ & : & \text { INFO USER.E2 } \\ & : & \text { INFO USER.82 } \\ & : & \text { INFO USER.E3 } \\ & \end{array}$


The watershed aggregation programs can be run on two regions by executing the above batch job "RUN". An example of the program sequence is illustrated below:

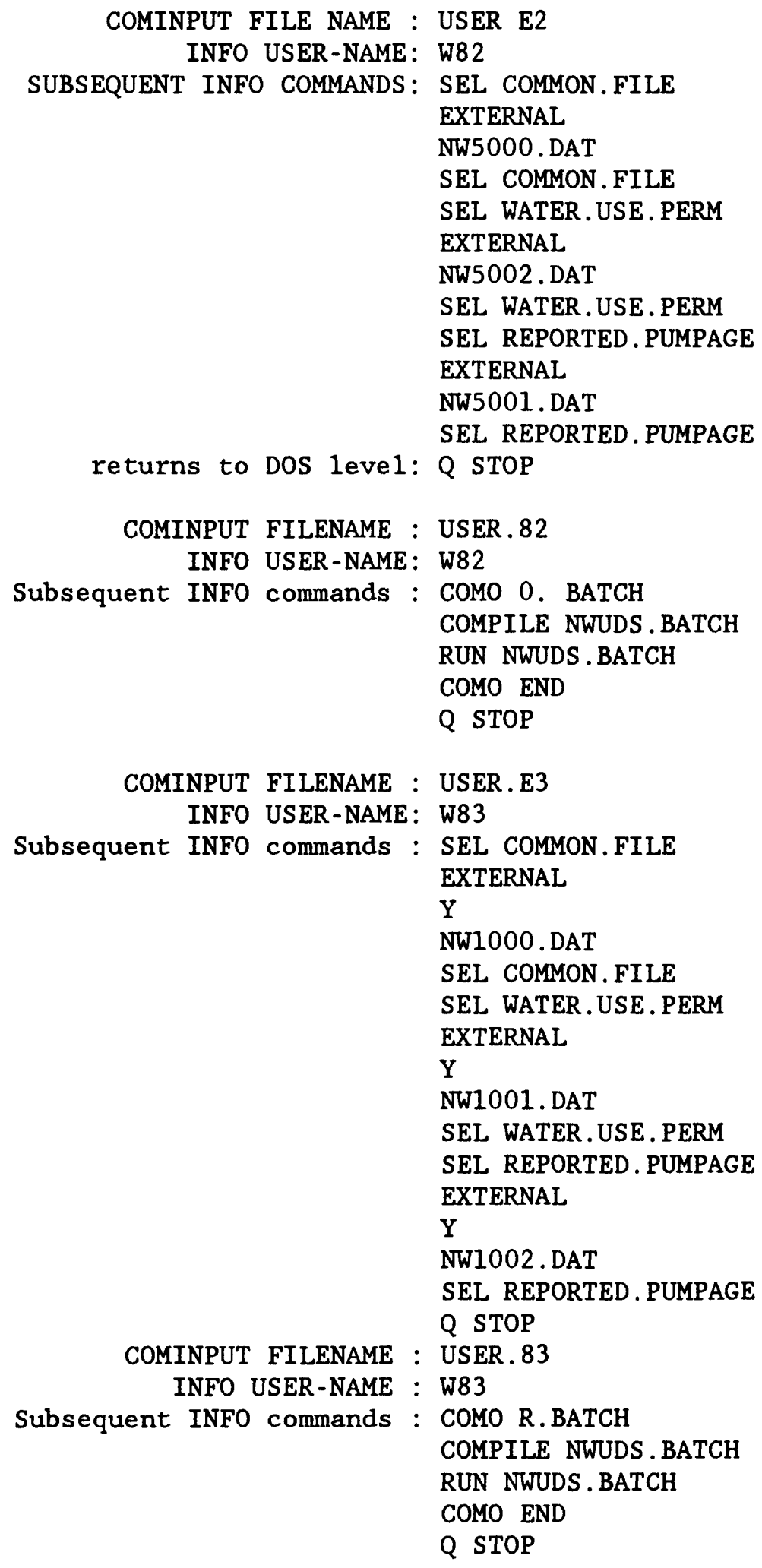




\section{Executing Watershed Irrigation Programs}

The irrigation programs PG.WIR, and PG.WIR2 should be executed in the following sequence because watershed boundaries cross regional boundaries. The program PG.WIRC should not be executed until regional watershed totals have been integrated into the statewide datafiles.

1) Run programs on regions $1 \& 5$ (PG.WIR, PG.WIR2)

2) SEL the irrigation datafiles (WIR, WIR2)

3) RES for IRW. GWNY GT 0 or IRW. SWNY GT 0

4) Save and compress the selected records into two ".SAM" files

5) Record the filenames to reload data into the appropriate irrigation datafiles.

6) ASE

7) PURGE all records

8) GET WAT.SAM COPY

9) CALC WATSHD.UNIT = WATSH.UNIT (for watershed units less than 10 , the leading zero is read as a blank)

10) Run programs on regions $2 \& 4$

11) Follow steps 2 - 9

12) Run programs on region 6

13) Follow steps 2 - 9

14) Run programs on region 3

15) For the watershed units which exist in more than one region, the data item values must be aggregated to get a statewide total

16) Run PG.IRR.COMBINE 


\section{NWUDS AGGREATION PROGRAMS}

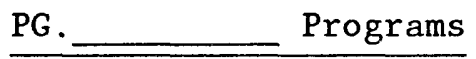

These programs calculate the county and watershed water use totals by specific use type. (Appendix A)

\begin{tabular}{lc}
\hline $\begin{array}{c}\text { County } \\
\text { aggregation } \\
\text { programs }\end{array}$ & $\begin{array}{c}\text { Watershed } \\
\text { aggregation } \\
\text { programs }\end{array}$ \\
\hline PG.MUNICIPAL & PG.WSW \\
PG.MUNNIES & PG.WMU \\
PG. COMMERCIAL & PG.WCO \\
PG. INDUSTRY & PG.WIN \\
PG.MINING & PG.WMI \\
PG.FOSSIL & PG.WPF \\
PG.WAWO & PG.WAW \\
PG.SEWAGE & PG.WST \\
PG.IRR.RICE & PG.WIR \\
PG.IRR.NORICE & PG.WIR2 \\
PG.IRR. COMBINE & PG.WIRC \\
PG.DOMESTIC & \\
\hline
\end{tabular}

Note: 1. Program PG.MUNNIES must be run prior to PG.MUNICIPAL

2. Programs PG.IRR.RICE and PG.IRR.NORICE must be run prior to PG.IRR. COMBINE.

See section program execution for procedures to follow when executing watershed irrigation programs.

The two nuclear power plant facilities in the state were incorporated into the fossil fuel aggregation reports. Permit number 661172 (NSP Montice11o Plant), and permit number 690172 (NSP Prairie Island Plant) are entered as use code 26 in the SWUDS. Permit number 670083 (NSP Monticello Plant) is a groundwater permit for industrial purposes, and permit number 690171 is a groundwater permit for the Prairie Island Nuclear Plant for commercial water use within the plant. 
These formatting programs calculate the year, calculate the federal county ID number from the State County number, converts annual totals from MGY to MGD (divides by 365 or 366), and adds the name of the data source agency. There are seven PG.FINAL programs for each use catergory for county and watershed totals.

\begin{tabular}{|c|c|}
\hline $\begin{array}{l}\text { County } \\
\text { aggregation } \\
\text { programs }\end{array}$ & $\begin{array}{l}\text { Watershed } \\
\text { aggregation } \\
\text { programs }\end{array}$ \\
\hline PG.FINAL.MUNICIPAL & PG.FINAL.WSW \\
\hline PG.FINAL. COMMERCIAL & PG. FINAL. WCO \\
\hline PG. FINAL. INDUSTRY & PG.FINAL.WIN \\
\hline PG. FINAL.SEWAGE & PG.FINAL. WST \\
\hline PG. FINAL. MINING & PG.FINAL.WMI \\
\hline PG.FINAL.FOSSIL & PG.FINAL.PFW \\
\hline PG. FINAL. IRRIGATION & PG.FINAL. WIR \\
\hline
\end{tabular}

Example:

Program name: PG.FINAL. IRRIGATION

10000 PROGRAM SECTION ONE

10001 SEL IRRIGATION.COMB

20000 PROGRAM SECTION TWO

20001. CALC YEAR $=83$

20002 CALC FEDID $=($ COUNTY $* 2)-1$

20003 CALC IRW.GWAND3 = ALL.WAT.G $/ 365$

20004 CALC IRW.SWNAD3 = ALL.WAT.S / 365

20005 CALC IRR.SWNAD3 $=$ (ALL.WAT.R * 0.33) $/ 365$

20006 MOVE 'IFMN DEPT OF NATURAL RESOURCES' TO IRW.GWNAD2

20007 MOVE 'IFMN DEPT OF NATURAL RESOURCES' TO IRW.SWNAD2

20008 MOVE 'EPU S GEOLOGICAL SURVEY' TO IRR. SWNAD2

30000 PROGRAM SECTION THREE 
These are the last sequence of programs to be run for the county or watershed aggregation reports. This formatting program creates an output file, which is the final output format for submission to the NWUDS in Reston, Virginia. The output-file name has the following format: NWREG380.COM which indicates the region, year and use type.

\begin{tabular}{ll}
\hline $\begin{array}{c}\text { County } \\
\text { aggregation } \\
\text { program }\end{array}$ & $\begin{array}{c}\text { Watershed } \\
\text { aggregation } \\
\text { program }\end{array}$ \\
\hline PG.REPORT.MUNICIPAL & PG.REPORT.WSW \\
PG. REPORT. COMMERCIAL & PG.REPORT.WCO \\
PG.REPORT. INDUSTRY & PG. REPORT.WIN \\
PG. REPORT. MINING & PG.REPORT.WMI \\
PG.REPORT. FOSSIL & PG.REPORT.WPF \\
PG.REPORT. SEWAGE & PG.REPORT.WST \\
PG. REPORT. IRRIGATION & PG.REPORT.WIR \\
\hline
\end{tabular}

Example:

Program name: PG.REPORT.MUNICIPAL

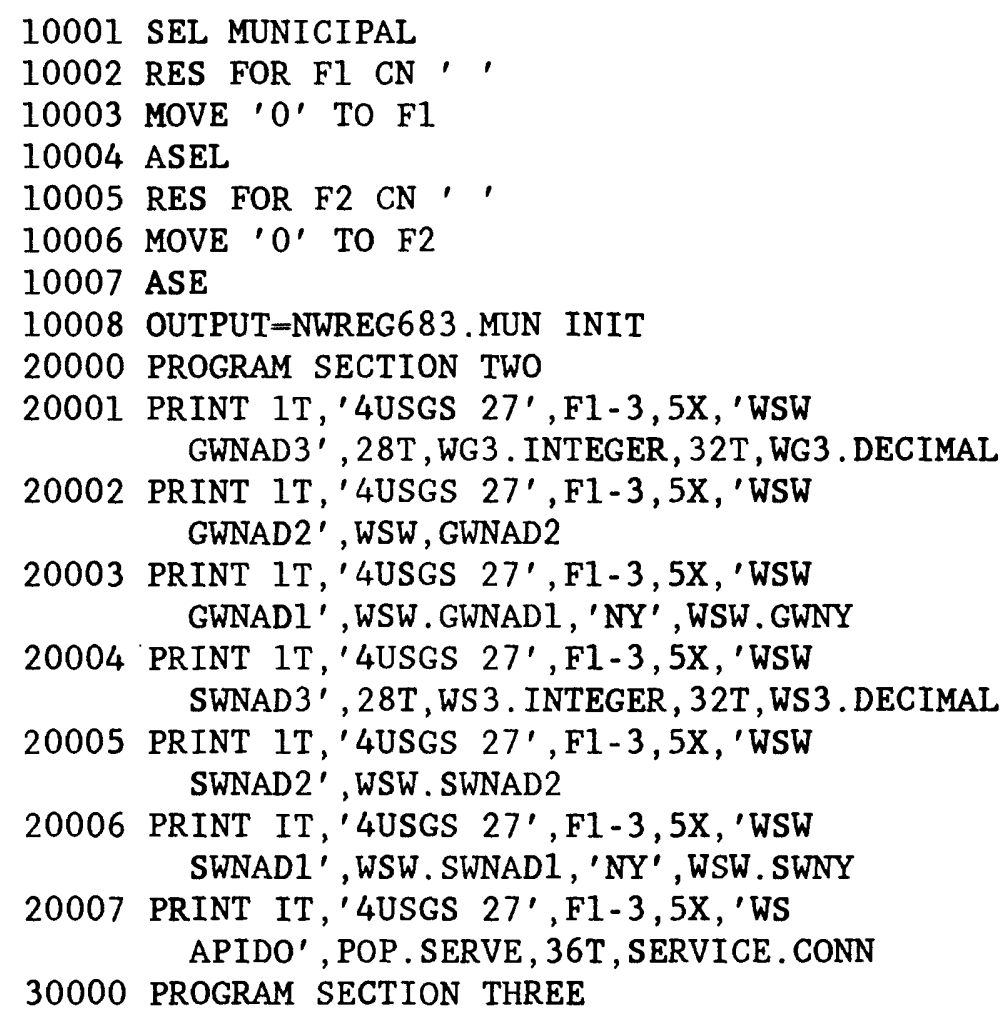


This is the master program to run the NWUDS aggregation programs. The INFO RUN PROGRAM with LINK option allows up to 50 programs to be executed in a consecutive order. With the LINK option, INFO cannot encounter a 'END'statement within a named program or INFO cancels the LINK request and returns control to the calling program.

FOR COUNTY AGGREGATION:

Program name: NWUDS.BATCH 10001 DIS \$TIME

10002 RUN PG.MUNNIES LINK

10003 RUN PG.MUNICIPAL LINK

10004 RUN PG.COMMERCIAL LINK

10005 RUN PG. INDUSTRY LINK

10006 RUN PG.MINING LINK

10007 RUN PG.FOSSIL LINK

10008 RUN PG.WAWO LINK

10009 RUN PG.SEWAGE I.INK

10010 RUN PG.IRR.RICE LINK

10011 RUN PG.IRR.NORICE LINK

10012 RUN PG.IRR. COMBINE LINK

10013 RUN PG.FINAL.MUNICIPAL LINK

10014 RUN PG.FINAL COMMERCIAL LINK

10015 RUN PG.FINAL. INDUSTRY LINK

10016 RUN PG.FINAL.MINING LINK

10017 RUN PG.FINAL. FOSSIL LINK

10018 RUN PG.FINAL.SEWAGE LINK

10019 RUN PG.FINAL. IRRIGATION LINK

10020 RUN PG.REPORT.MUNICIPAL LINK

10021 RUN PG.REPORT.COMMERCIAL LINK

10022 RUN PG.REPORT. INDUSTRY LINK

10024 RUN PG.REPORT.FOSSIL LINK

10025 RUN PG.REPORT.SEWAGE LINK

10026 RUN PG.REPORT.IRRIGATION LINK

10027 DIS \$TIME

10028 Q STOP 


\section{COUNTY AGGREGATION DATAFILES}

The datafile structure, as of September 5, 1985, for each of the county aggregation datafiles is shown on the following pages. For each of the items in the datafiles the following characteristics are given:

COL- - The starting column for the item.

ITEM NAME--The name of the item.

WDTH--The width of the item in the file.

OPUT--The number of spaces needed to display or print the item values.

TYP--The item type:

C--Character; the letters of the alphabet, punctuation, and numbers that are not numeric values.

I--Integer; numbers without decimal places.

$\mathrm{N}$--Numeric; numbers that can have decimal places.

D--Date; month, day, and year.

N.Dec--The number of decimal places if the item is numeric.

ALTERNATE NAME--An alternate name to be used for the item if one exists.

Redefined items are used to change the datafile templates to fit changing data needs. A redefined item can specify a combination of adjacent items or a subset of an item or items. The characteristics for the redefined items follow the characteristics for the items. 
DATAFILE NAME: MUNICIPAL

\begin{tabular}{|c|c|c|c|c|c|c|}
\hline 22 & ITEMS: STARTING II & IN POS & ITION & & 1 & \\
\hline COL & ITEM NAME & WDTH & OPUT & TYP & N.DEC & ALTERNATE NAME \\
\hline 1 & COUNTY & 2 & 2 & I & - & \\
\hline 3 & FEDID & 3 & 3 & I & - & \\
\hline 6 & YEAR & 2 & 2 & I & - & \\
\hline 8 & WSW. GWNAD 3 & 10 & 10 & $\mathrm{~N}$ & 2 & \\
\hline 18 & WSW. GWNAD2 & 40 & 40 & C & - & \\
\hline 58 & WSW. GWNAD1 & 5 & 5 & I & - & \\
\hline 63 & WSW. GWNY & 5 & 5 & I & - & \\
\hline 68 & WSW. SWNAD 3 & 10 & 10 & $\mathrm{~N}$ & 2 & \\
\hline 78 & WSW. SWNAD2 & 40 & 40 & $\mathrm{C}$ & - & \\
\hline 118 & WSW. SWNAD1 & 5 & 5 & I & - & \\
\hline 123 & WSW. SWNY & 5 & 5 & I & - & \\
\hline 128 & WSW. GWRV & 10 & 10 & $\mathrm{~N}$ & 2 & \\
\hline 138 & WSW. GWEV & 10 & 10 & $\mathrm{~N}$ & 2 & \\
\hline 148 & WSW.GWEI & 5 & 5 & I & - & \\
\hline 153 & WSW. SWRV & 10 & 10 & $\mathrm{~N}$ & 2 & \\
\hline 163 & WSW. SWEV & 10 & 10 & $\mathrm{~N}$ & 2 & \\
\hline 173 & WSW. SWEI & 5 & 5 & I & - & \\
\hline 178 & WSW.POP & 7 & 7 & I & - & \\
\hline 185 & WSW.CONNECTIONS & 7 & 7 & I & - & \\
\hline 192 & DUMMYO & 100 & 100 & $\mathrm{C}$ & - & \\
\hline 292 & SERVICE.CONN & 7 & 7 & I & - & \\
\hline 299 & POP.SERVE & 7 & 7 & I & - & \\
\hline \multicolumn{6}{|c|}{$* *$ REDEFINED ITEMS $* *$} & \\
\hline 1 & ID & 5 & 5 & I & - & \\
\hline 3 & F1 & 1 & 1 & $\mathrm{C}$ & - & \\
\hline 4 & F2 & 1 & 1 & C & - & \\
\hline 5 & F3 & 1 & 1 & $\mathrm{C}$ & - & \\
\hline 3 & F1-3 & 3 & 3 & C & - & \\
\hline 11 & WG3. INTEGER & 4 & 4 & $C$ & - & \\
\hline 16 & WG3. DECIMAL & 2 & 2 & C & - & \\
\hline 71 & WS3. INTEGER & 4 & 4 & C & - & \\
\hline 76 & WS 3. DECIMAL & 2 & 2 & C & - & \\
\hline 6 & DATA & 273 & 200 & C & - & \\
\hline
\end{tabular}


DATAFILE NAME: MUNNIES

\begin{tabular}{|c|c|c|c|c|c|c|}
\hline 24 & ITEMS: STARTINC & G IN POS & ITION & 1 & 1 & \\
\hline $\mathrm{COL}$ & ITEMS NAME & WDTH & OPUT & TYP & N. DEC & ALTERNATE NAME \\
\hline 1 & COUNTY & 2 & 2 & I & - & \\
\hline 3 & FEDID & 3 & 3 & I & - & \\
\hline 6 & YEAR & 2 & 2 & $I$ & - & \\
\hline 8 & MUW. GWNAD3 & 10 & 10 & $\mathrm{~N}$ & 2 & \\
\hline 18 & MUW. GWNAD2 & 40 & 40 & C & - & \\
\hline 58 & MUW. GWNAD1 & 5 & 5 & I & - & \\
\hline 63 & MUW. GWNY & 5 & 5 & I & - & \\
\hline 68 & MUW. SWNAD3 & 10 & 10 & $\mathrm{~N}$ & 2 & \\
\hline 78 & MUW. SWNAD1 & 40 & 40 & C & - & \\
\hline 118 & MUW. SWNDA1 & 5 & 5 & I & - & \\
\hline 123 & MUW. SWNY & 5 & 5 & $I$ & - & \\
\hline 128 & MUW. GWRY & 10 & 10 & $\mathrm{~N}$ & 2 & \\
\hline 138 & MUW. GWEV & 10 & 10 & $\mathrm{~N}$ & 2 & \\
\hline 148 & MUW. GWEI & 5 & 5 & I & - & \\
\hline 153 & MUW. SWRV & 10 & 10 & $\mathrm{~N}$ & 2 & \\
\hline 163 & MUW. SWEV & 10 & 10 & $\mathrm{~N}$ & 2 & \\
\hline 173 & MUW. SEWI & 5 & 5 & I & - & \\
\hline 178 & MUW. POP . GW & 7 & 7 & I & - & \\
\hline 185 & MUW. POP.SW & 7 & 7 & I & - & \\
\hline 192 & MUW. CONNEC. GW & 7 & 7 & I & - & \\
\hline 199 & MUW. CONNEC. SW & 7 & 7 & I & - & \\
\hline 206 & DUMMYO & 50 & 50 & C & - & \\
\hline 256 & SERVICE.CONN & 7 & 7 & I & - & \\
\hline 263 & POP. SERVE & 7 & 7 & I & - & \\
\hline & $\star *$ REDEFINED & ITEMS $* *$ & & & & \\
\hline 1 & ID & 5 & 5 & I & - & \\
\hline 3 & F1 & 1 & 1 & C & - & \\
\hline 4 & F2 & 1 & 1 & C & - & \\
\hline 5 & F3 & 1 & 1 & C & - & \\
\hline 3 & F1-3 & 3 & 3 & C & - & \\
\hline 11 & WG3. INTEGER & 4 & 4 & C & - & \\
\hline 16 & WG3. DECIMAL & 2 & 2 & C & - & \\
\hline 71 & WS3. INTEGER & 4 & 4 & $\mathrm{C}$ & - & \\
\hline 76 & WS 3. DECIMAL & 2 & 2 & $\mathrm{C}$ & - & \\
\hline
\end{tabular}


DATAFILE NAME: WATERWORKS

18 ITEMS: STARTING IN POSITION 1

\begin{tabular}{|c|c|c|c|c|c|c|c|}
\hline COL & ITEM NAME & WDTH & OPUT & TYP & N.DEC & ALTERNATE & NAME \\
\hline 1 & COUNTY & 2 & 2 & I & - & & \\
\hline 3 & FEDID & 3 & 3 & I & - & & \\
\hline 6 & YEAR & 2 & 2 & I & - & & \\
\hline 8 & WAW. GWNAD3 & 10 & 10 & $\mathrm{~N}$ & 2 & & \\
\hline 18 & WAW. GWNAD2 & 40 & 40 & $\mathrm{C}$ & - & & \\
\hline 58 & WAW. GWNAD1 & 5 & 5 & I & - & & \\
\hline 63 & WAW. GWNY & 5 & 5 & I & - & & \\
\hline 68 & WAW. SWNAD3 & 10 & 10 & $\mathrm{~N}$ & 2 & & \\
\hline 78 & WAW. SWNAD2 & 40 & 40 & C & - & & \\
\hline 118 & WAW . SWNAD1 & 5 & 5 & I & - & & \\
\hline 123 & WAW. SWNY & 5 & 5 & I & - & & \\
\hline 128 & WAW. GWRV & 10 & 10 & $\mathrm{~N}$ & 2 & & \\
\hline 138 & WAW. GWEV & 10 & 10 & $\mathrm{~N}$ & 2 & & \\
\hline 148 & WAW. GWEI & 5 & 5 & $I$ & - & & \\
\hline 153 & WAW. SWRV & 10 & 10 & $\mathrm{~N}$ & 2 & & \\
\hline 163 & WAW . SWEV & 10 & 10 & $\mathrm{~N}$ & 2 & & \\
\hline 173 & DUMMYO & 50 & 50 & C & - & & \\
\hline & ** REDEFINED & ITEMS $* *$ & & & & & \\
\hline 1 & ID & 5 & 5 & I & - & & \\
\hline 3 & FI & 1 & 1 & C & - & & \\
\hline 4 & F2 & 1 & 1 & C & - & & \\
\hline 5 & F3 & 1 & 1 & C & - & & \\
\hline 3 & F1-3 & 3 & 3 & C & - & & \\
\hline 11 & WG3. INTEGER & 4 & 4 & $\mathrm{C}$ & - & & \\
\hline 16 & WG3.DECIMAL & 2 & 2 & C & - & & \\
\hline 71 & WS 3. INTEGER & 4 & 4 & C & - & & \\
\hline 76 & WS 3. DECIMAL & 2 & 2 & C & - & & \\
\hline
\end{tabular}


DATAFILE NAME: COMMERCIAL

22 ITEMS: STARTING IN POSITION 1

COL ITEMS NAME

1 COUNTY

WDTH OPUT TYP N.DEC ALTERNATE NAME

3 FEDID

6 YEAR

8 COW.GWNAD3

15 COW. GWNAD2

55 COW. GWNAD1

60 COW. GWNY

65 COW. SWNAD3

72 COW. SWNAD2

112 COW. SWNAD1

117 COW. SWNY

122 COR. SWNAD3

129 COR. SWNAD2

169 COR. SWNAD1

174 COR. SWNY

179 COW. GWRV

189 COW.GWEV

199 COW.GWEI

204 COW. SWRV

214 COW. SWEV

224 COW. SWEI

229 DUMMYO

** REDEFINED

$2 \quad 2$ I

$\begin{array}{lll}3 & 3 & I\end{array}$

$\begin{array}{lll}2 & 2 & I\end{array}$

$7 \quad 7 \mathrm{~N}$

$40 \quad 40 \quad C$

$\begin{array}{lll}5 & 5 & \text { I }\end{array}$

$\begin{array}{lll}5 & 5 & I\end{array}$

$7 \quad 7 \mathrm{~N}$

$40 \quad 40 \quad C$

555

$\begin{array}{lll}5 & 5 & I\end{array}$

$\begin{array}{llll}7 & 7 & \mathrm{~N} & 2\end{array}$

$\begin{array}{llll}40 & 40 & \mathrm{C} & -\end{array}$

55 I -

555 I

$\begin{array}{llll}10 & 10 & \mathrm{~N} & 2\end{array}$

$\begin{array}{llll}10 & 10 & \mathrm{~N} & 2\end{array}$

55 I -

$\begin{array}{llll}10 & 10 & \mathrm{~N} & 2\end{array}$

$\begin{array}{llll}10 & 10 & \mathrm{~N} & 2\end{array}$

3 F1

4 F2

5 F3

3 Fl-3

8 WG3. INTEGER

13 WG3. DECIMAL

65 WS 3 . INTEGER

70 WS3.DECIMAL

122 RS3. INTEGER

127 RS3.DECIMAL

6 DATA

1 ID

$100100 \quad \mathrm{C}$

ITEMS **

$\begin{array}{rrrr}1 & 1 & \mathrm{C} & - \\ 1 & 1 & \mathrm{C} & - \\ 1 & 1 & \mathrm{C} & - \\ 3 & 3 & \mathrm{C} & - \\ 4 & 4 & \mathrm{C} & - \\ 2 & 2 & \mathrm{C} & - \\ 4 & 4 & \mathrm{C} & - \\ 2 & 2 & \mathrm{C} & - \\ 4 & 4 & \mathrm{C} & - \\ 2 & 2 & \mathrm{C} & - \\ 273 & 200 & \mathrm{C} & - \\ 5 & 5 & \mathrm{C} & -\end{array}$


DATAFILE NAME: INDUSTRY

22 ITEMS: STARTING IN POSITION 1

\begin{tabular}{|c|c|c|c|c|c|c|}
\hline COL & ITEM NAME & WDTH & OPUT & TYP & N.DEC & ALTERNATE NAME \\
\hline 1 & COUNTY & 2 & 2 & I & - & \\
\hline 3 & FEDID & 3 & 3 & I & - & \\
\hline 6 & YEAR & 2 & 2 & I & - & \\
\hline 8 & INW. GWNAD3 & 10 & 10 & $\mathrm{~N}$ & 2 & \\
\hline 18 & INW. GWNAD2 & 40 & 40 & C & - & \\
\hline 58 & INW . GWNAD1 & 5 & 5 & I & - & \\
\hline 63 & INW. GWNYY & 5 & 5 & $I$ & - & \\
\hline 68 & INW. SWNAD3 & 10 & 10 & $\mathrm{~N}$ & 2 & \\
\hline 78 & INW. SWNAD2 & 40 & 40 & C & - & \\
\hline 118 & INW. SWNAD1 & 5 & 5 & I & - & \\
\hline 123 & INW. SWNY & 5 & 5 & $\mathbf{I}$ & - & \\
\hline 128 & INR . SWNAD 3 & 10 & 10 & $\mathrm{~N}$ & 2 & \\
\hline 138 & INR. SWNAD2 & 40 & 40 & C & - & \\
\hline 178 & INR. SWNAD1 & 5 & 5 & I & - & \\
\hline 183 & INR . SWNY & 5 & 5 & I & - & \\
\hline 188 & INW. GWRV & 10 & 10 & $\mathrm{~N}$ & 2 & \\
\hline 198 & INW.GWEV & 10 & 10 & $\mathrm{~N}$ & 2 & \\
\hline 208 & INW.GWEI & 5 & 5 & I & - & \\
\hline 213 & INW. SWRV & 10 & 10 & $\mathrm{~N}$ & 2 & \\
\hline 223 & INW. SWEV & 10 & 10 & $\mathrm{~N}$ & 2 & \\
\hline 233 & INW. SWEI & 5 & 5 & I & - & \\
\hline \multirow[t]{2}{*}{238} & DUMMYO & 100 & 100 & \multirow[t]{2}{*}{$\mathrm{C}$} & \multirow[t]{2}{*}{ - } & \\
\hline & ** REDEFINED & \multicolumn{2}{|c|}{ ITEMS ** } & & & \\
\hline 3 & F1 & 1 & 1 & C & - & \\
\hline 4 & F2 & 1 & 1 & C & - & \\
\hline 5 & F3 & 1 & 1 & C & - & \\
\hline 3 & F1-3 & 3 & 3 & C & - & \\
\hline 11 & WG3. INTEGER & 4 & 4 & C & - & \\
\hline 16 & WG3 . DECIMAL & 2 & 2 & C & - & \\
\hline 71 & WS 3. INTEGER & 4 & 4 & C & - & \\
\hline 76 & WS 3. DECIMAL & 2 & 2 & C & - & \\
\hline 131 & RS3. INTEGER & 4 & 4 & C & - & \\
\hline 136 & RS 3. DECIMAL & 2 & 2 & C & - & \\
\hline 6 & DATA & $27 \overline{3}$ & 200 & C & - & \\
\hline 1 & ID & 5 & 5 & I & - & \\
\hline
\end{tabular}


DATAFILE NAME: MINING

22 ITEMS: STARTING IN POSITION 1

$\begin{array}{rlrrrr}\text { COL } & \text { ITEM NAME } & \text { WDTH } & \text { OPUT } & \text { TYP } & \text { N. DEC } \\ 1 & \text { COUNTY } & 2 & 2 & 1 & - \\ 3 & \text { FEDID } & 3 & 3 & 1 & - \\ 6 & \text { YEAR } & 2 & 2 & 1 & - \\ 8 & \text { MIW. GWNAD3 } & 10 & 10 & \mathrm{~N} & 2 \\ 18 & \text { MIW. GWNAD2 } & 40 & 40 & \mathrm{C} & - \\ 58 & \text { MIW. GWNAD1 } & 5 & 5 & \mathrm{I} & - \\ 63 & \text { MIW. GWNY } & 5 & 5 & \mathrm{I} & - \\ 68 & \text { MIW. SWNAD3 } & 10 & 10 & \mathrm{~N} & 2 \\ 78 & \text { MIW. SWNAD2 } & 40 & 40 & \mathrm{C} & - \\ 118 & \text { MIW. SWNAD1 } & 5 & 5 & \mathrm{I} & - \\ 123 & \text { MIW.SWNY } & 5 & 5 & \mathrm{I} & - \\ 128 & \text { MIR.SWNAD3 } & 10 & 10 & \mathrm{~N} & 2 \\ 138 & \text { MIR. SWNAD2 } & 40 & 40 & \mathrm{C} & - \\ 178 & \text { MIR. SWNAD1 } & 5 & 5 & \mathrm{I} & - \\ 183 & \text { MIR. SWNY } & 5 & 5 & \mathrm{I} & - \\ 188 & \text { MIW. GWRV } & 10 & 10 & \mathrm{~N} & 2 \\ 198 & \text { MIW. GWEV } & 10 & 10 & \mathrm{~N} & 2 \\ 208 & \text { MIW. GWEI } & 5 & 5 & \mathrm{I} & - \\ 213 & \text { MIW. SWRV } & 10 & 10 & \mathrm{~N} & 2 \\ 223 & \text { MIW. SWEV } & 10 & 10 & \mathrm{~N} & 2 \\ 233 & \text { MIW.SWEI } & 5 & 5 & \mathrm{I} & - \\ 238 & \text { DUMMYO } & 100 & 100 & \mathrm{C} & - \\ & \text { ** REDEFINED ITEMS } & * * & & & \\ 3 & \text { F1 } & 1 & 1 & \mathrm{C} & - \\ 4 & \text { F2 } & 1 & 1 & \mathrm{C} & - \\ 5 & \text { F3 } & 1 & 1 & \mathrm{C} & - \\ 3 & \text { F1-3 } & 3 & 3 & \mathrm{C} & - \\ 11 & \text { WG3. INTEGER } & 4 & 4 & \mathrm{C} & - \\ 16 & \text { WG3.DECIMAL } & 2 & 2 & \mathrm{C} & - \\ 71 & \text { WS3. INTEGER } & 4 & 4 & \mathrm{C} & - \\ 76 & \text { WS3.DECIMAL } & 2 & 2 & \mathrm{C} & - \\ 131 & \text { RS3. INTEGER } & 4 & 4 & \mathrm{C} & - \\ 136 & \text { RS3.DECIMAL } & 2 & 2 & \mathrm{C} & - \\ 6 & \text { DATA } & 273 & 200 & \mathrm{C} & - \\ 1 & \text { ID } & 5 & 5 & \mathrm{C} & - \\ & & & & & \end{array}$


DATAFILE NAME: FOSSIL

22 ITEMS: STARTING IN POSITION 1

COL ITEM NAME

1 COUNTY

3 FEDID

6 YEAR

8 PFW.GWNAD3

18 PFW. GWNAD2

58 PFW. GWNAD1

63 PFW. GWNY

68 PFW. SWNAD3

78 PFW. SWNAD2

118 PFW. SWNAD1

123 PFW. SWNY

128 PFR. SWNAD3

138 PFR. SWNAD2

178 PFR. SWNAD1

183 PFR. SWNY

188 PFW.GWRV

198 PFW. GWEV

208 PFW. GWEI

213 PFW. SWRV

223 PFW. SWEV

233 PFW. SWEI

238 DUMMYO WDTH OPUT TYP N.DEC ALTERNATE NAME ** REDEFINED ITEMS

$\begin{array}{rrrr}2 & 2 & \mathrm{I} & - \\ 3 & 3 & \mathrm{I} & - \\ 2 & 2 & \mathrm{I} & - \\ 10 & 10 & \mathrm{~N} & 2 \\ 40 & 40 & \mathrm{C} & - \\ 5 & 5 & \mathrm{I} & - \\ 5 & 5 & \mathrm{I} & - \\ 10 & 10 & \mathrm{~N} & 2 \\ 40 & 40 & \mathrm{C} & - \\ 5 & 5 & \mathrm{I} & - \\ 5 & 5 & \mathrm{I} & - \\ 10 & 10 & \mathrm{~N} & 2 \\ 40 & 40 & \mathrm{C} & - \\ 5 & 5 & \mathrm{I} & - \\ 5 & 5 & \mathrm{I} & - \\ 10 & 10 & \mathrm{~N} & 2 \\ 10 & 10 & \mathrm{~N} & 2 \\ 5 & 5 & \mathrm{I} & - \\ 10 & 10 & \mathrm{~N} & 2 \\ 10 & 10 & \mathrm{~N} & 2 \\ 5 & 5 & \mathrm{I} & - \\ 100 & 100 & \mathrm{C} & - \\ * * & & & \end{array}$

$\begin{aligned} 3 & \text { F1 } \\ 4 & \text { F2 } \\ 5 & \text { F3 } \\ 3 & \text { F1-3 } \\ 11 & \text { WG3. INTEGER } \\ 16 & \text { WG3. DECIMAL } \\ 71 & \text { WS3. INTEGER } \\ 76 & \text { WS3. DECIMAL } \\ 131 & \text { RS3. INTEGER } \\ 136 & \text { RS3. DECIMAL } \\ 6 & \text { DATA } \\ 1 & \text { ID }\end{aligned}$

$\begin{array}{rrrr}1 & 1 & \mathrm{C} & - \\ 1 & 1 & \mathrm{C} & - \\ 1 & 1 & \mathrm{C} & - \\ 3 & 3 & \mathrm{C} & - \\ 4 & 4 & \mathrm{C} & - \\ 2 & 2 & \mathrm{C} & - \\ 4 & 4 & \mathrm{C} & - \\ 2 & 2 & \mathrm{C} & - \\ 4 & 4 & \mathrm{C} & - \\ 2 & 2 & \mathrm{C} & - \\ 273 & 200 & \mathrm{C} & - \\ 5 & 5 & \mathrm{C} & -\end{array}$


DATAFILE NAME: SEWAGE

24 ITEMS: STARTING IN POSITION 1

COL ITEM NAME

1 COUNTY

3 FEDID

6 YEAR

8 STW.GWNAD3

18 STW.GWNAD2

58 STW. GWNAD1

63 STW. GWNY

68 STW. SWNAD3

78 STW. SWNAD2

118 STW. SWNAD1

123 STW. SWNY

128 STR. SWNAD3

138 STR. SWNAD2

178 STR. SWNAD1

183 STR. SWNY

188 STW.GWRV

198 STW.GWEV

208 STW.GWEI

213 STW.SWRV

223 STW. SWEV

233 STW. SWEI

238 POP.SERVE

245 SERVICE. CONN

252 DUMMYO

WDTH OPUT TYP N.DEC ALTERNATE NAME ** REDEFINED ITEMS

$\begin{array}{rrrl}2 & 2 & \mathrm{I} & - \\ 3 & 3 & \mathrm{I} & - \\ 2 & 2 & \mathrm{I} & - \\ 10 & 10 & \mathrm{~N} & 2 \\ 40 & 40 & \mathrm{C} & - \\ 5 & 5 & \mathrm{I} & - \\ 5 & 5 & \mathrm{I} & - \\ 10 & 10 & \mathrm{~N} & 2 \\ 40 & 40 & \mathrm{C} & - \\ 5 & 5 & \mathrm{I} & - \\ 5 & 5 & \mathrm{I} & - \\ 10 & 10 & \mathrm{~N} & 2 \\ 40 & 40 & \mathrm{C} & - \\ 5 & 5 & \mathrm{I} & - \\ 5 & 5 & \mathrm{I} & - \\ 10 & 10 & \mathrm{~N} & 2 \\ 10 & 10 & \mathrm{~N} & 2 \\ 5 & 5 & \mathrm{I} & - \\ 10 & 10 & \mathrm{~N} & 2 \\ 10 & 10 & \mathrm{~N} & 2 \\ 5 & 5 & \mathrm{I} & - \\ 7 & 7 & \mathrm{I} & - \\ 7 & 7 & \mathrm{I} & - \\ 100 & 100 & \mathrm{C} & - \\ \star * & & & \end{array}$

$\begin{aligned} 1 & \text { ID } \\ 3 & \text { F1 } \\ 4 & \text { F2 } \\ 5 & \text { F3 } \\ 3 & \text { F1-3 } \\ 11 & \text { WG3. INTEGER } \\ 16 & \text { WG3. DECIMAL } \\ 71 & \text { WS3. INTEGER } \\ 76 & \text { WS3.DECIMAL } \\ 6 & \text { DATA } \\ 131 & \text { RS3.INTEGER } \\ 136 & \text { RS3.DECIMAL }\end{aligned}$

$\begin{array}{rrrr}5 & 5 & \text { I } & - \\ 1 & 1 & \text { C } & - \\ 1 & 1 & \text { C } & - \\ 1 & 1 & \text { C } & - \\ 3 & 3 & \text { C } & - \\ 4 & 4 & \text { C } & - \\ 2 & 2 & \text { C } & - \\ 4 & 4 & \text { C } & - \\ 2 & 2 & \text { C } & - \\ 273 & 200 & \text { C } & - \\ 4 & 4 & \text { C } & - \\ 2 & 2 & \text { C } & -\end{array}$


DATAFILE NAME: IRRIGATION

38 ITEMS: STARTING IN POSITION 1

COL ITEM NAME

1 COUNTY

FEDID

6 YEAR

8 IRW.GWNAD3

18 IRW. GWNAD2

58 IRW. GWNAD1

63 IRW. GWNY

68 IRW. SWNAD3

78 IRW. SWNAD2

118 IRW. SWNAD1

123 IRW. SWNY

128 IRR. SWNAD3

138 IRR. SWNAD2

178 CO.ACRE.S

184 CO.ACRE.G

190 REP.ACRE.S

196 REP.ACRE.G

202 PERM.ACRE.S

208 PERM.ACRE.G

214 PCNT.IRR.ACRE.S

220 PCNT. IRR. ACRE.G

226 EST.ACRE.S

232 EST.ACRE.G

238 REP.WAT.S

248 REP.WAT.G

258 GAL.ACRE.S

268 GAL.ACRE.G

278 GAL.ACRE.R

288 EST.WAT.S

298 EST.WAT.G

308 ALL.ACRE.S

314 ALL.ACRE.G

320

330

340

350

356

362

WDTH OPUT TYP N.DEC ALTERNATE NAME

$\begin{array}{lll}2 & 2 & 1\end{array}$

333 I

221

$\begin{array}{llll}10 & 10 & \mathrm{~N} & 2\end{array}$

4040 C -

55 I -

55 I -

$\begin{array}{llll}10 & 10 & \mathrm{~N} & 2\end{array}$

4040 C -

$\begin{array}{llll}5 & 5 & \text { I } & - \\ 5 & 5 & \text { I } & -\end{array}$

$\begin{array}{llll}10 & 10 & \mathrm{~N} & 2\end{array}$

4040 C -

$\begin{array}{llll}6 & 6 & I & - \\ 6 & 6 & I & -\end{array}$

66 I -

66 I -

$6 \quad 6$ I -

$6 \quad 6$ I -

$\begin{array}{llll}6 & 6 & \mathrm{~N} & 2\end{array}$

$\begin{array}{llll}6 & 6 & \mathrm{~N} & 2\end{array}$

$6 \quad 6$ I -

$6 \quad 6$ I -

$\begin{array}{llll}10 & 10 & \mathrm{~N} & 2\end{array}$

$\begin{array}{llll}10 & 10 & \mathrm{~N} & 2\end{array}$

$\begin{array}{llll}10 & 10 & \mathrm{~N} & 2\end{array}$

$\begin{array}{llll}10 & 10 & \mathrm{~N} & 2\end{array}$

$\begin{array}{llll}10 & 10 & \mathrm{~N} & 2\end{array}$

$\begin{array}{llll}10 & 10 & \mathrm{~N} & 2\end{array}$

$\begin{array}{llll}10 & 10 & \mathrm{~N} & 2\end{array}$

$\begin{array}{llll}6 & 6 & \mathrm{I} & - \\ 6 & 6 & \mathrm{I} & -\end{array}$

$\begin{array}{lllll}\text { ALL.WAT.S } & 10 & 10 & \mathrm{~N} & 2\end{array}$

$\begin{array}{lllll}\text { ALL.WAT.G } & 10 & 10 & \mathrm{~N} & 2\end{array}$

$\begin{array}{lllll}\text { ALL.WAT. } & 10 & 10 & \mathrm{~N} & 2\end{array}$

$\begin{array}{lrrrr}\text { IN.ACRE.NORICE } & 6 & 6 & \mathrm{~N} & 2\end{array}$

IN.ACRE.RICE $\quad 6 \quad 6 \quad \mathrm{~N} 2$

DUMMYO $100100 \mathrm{C}$ -

** REDEFINED ITEMS **

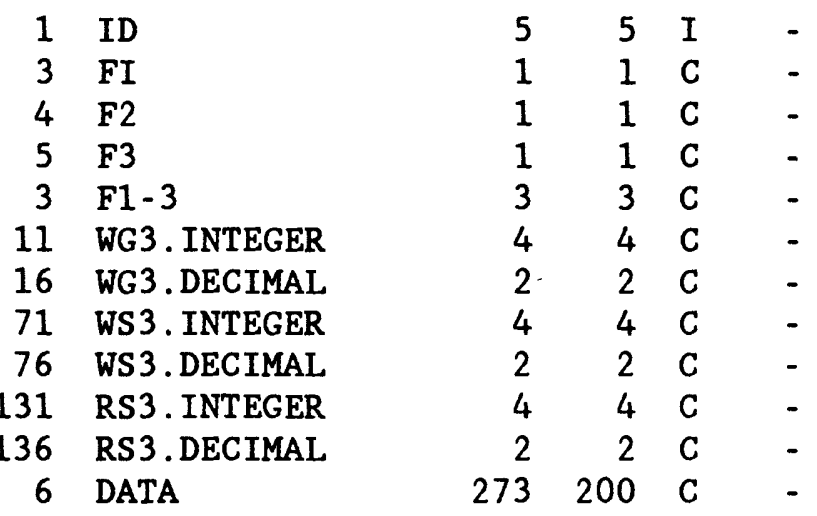


38 ITEMS: STARTING IN POSITION 1

COL ITEM NAME

1 COUNTY

3 FEDID

6 YEAR

8 IRW. GWNAD3

18 IRW.GWNAD2

58 IRW. GWNAD1

63 IRW. GWNY

68 IRW.SWNAD3

78 IRW. SWNAD2

118 IRW. SWNAD1

123 IRW. SWNY

128 IRR. SWNAD3

138 IRR. SWNAD2

178 CO.ACRE.S

184 CO.ACRE.G

190 REP.ACRE.S

196 REP.ACRE.G

202 PERM.ACRE.S

208 PER.ACRE.G

214 PCNT. IRR. ACRE.S

220 PCNT. IRR. ACRE.G

226 EST.ACRE.S

232 EST.ACRE.G

238 REP.WAT.S

248 REP.WAT.G

258 GAL.ACRE.S

268 GAL.ACRE.G

278 GAL.ACRE.R

288 EST.WAT.S

298 EST.WAT.G

308 ALL.ACRE.S

314 ALL.ACRE.G

320 ALL.WAT.S

330 ALL.WAT.G

340 ALL.WAT. R

350 IN.ACRE.NORICE

356 IN.ACRE.RICE

362 DUMMYO ** REDEFINED ITEM
WDTH OPUT TYP N.DEC ALTERNATE NAME

$\begin{array}{rrrl}2 & 2 & \mathrm{I} & - \\ 3 & 3 & \mathrm{I} & - \\ 2 & 2 & \mathrm{I} & - \\ 10 & 10 & \mathrm{~N} & 2 \\ 40 & 40 & \mathrm{C} & - \\ 5 & 5 & \mathrm{I} & - \\ 5 & 5 & \mathrm{I} & - \\ 10 & 10 & \mathrm{~N} & 2 \\ 40 & 40 & \mathrm{C} & - \\ 5 & 5 & \mathrm{I} & - \\ 5 & 5 & \mathrm{I} & - \\ 10 & 10 & \mathrm{~N} & 2 \\ 40 & 40 & \mathrm{C} & - \\ 6 & 6 & \mathrm{I} & - \\ 6 & 6 & \mathrm{I} & - \\ 6 & 6 & \mathrm{I} & - \\ 6 & 6 & \mathrm{I} & - \\ 6 & 6 & \mathrm{I} & - \\ 6 & 6 & \mathrm{I} & - \\ 6 & 6 & \mathrm{~N} & 2 \\ 6 & 6 & \mathrm{~N} & 2 \\ 6 & 6 & \mathrm{I} & - \\ 6 & 6 & \mathrm{I} & - \\ 10 & 10 & \mathrm{~N} & 2 \\ 10 & 10 & \mathrm{~N} & 2 \\ 10 & 10 & \mathrm{~N} & 2 \\ 10 & 10 & \mathrm{~N} & 2 \\ 10 & 10 & \mathrm{~N} & 2 \\ 10 & 10 & \mathrm{~N} & 2 \\ 10 & 10 & \mathrm{~N} & 2 \\ 6 & 6 & \mathrm{I} & - \\ 6 & 6 & \mathrm{I} & - \\ 10 & 10 & \mathrm{~N} & 2 \\ 10 & 10 & \mathrm{~N} & 2 \\ 10 & 10 & \mathrm{~N} & 2 \\ 6 & 6 & \mathrm{~N} & 2 \\ 6 & 6 & \mathrm{~N} & 2 \\ 100 & 100 & \mathrm{C} & - \\ & & -\end{array}$

$\begin{aligned} 1 & \text { ID } \\ 3 & \text { F1 } \\ 4 & \text { F2 } \\ 5 & \text { F3 } \\ 3 & \text { F1-3 } \\ 11 & \text { WG3. INTEGER } \\ 16 & \text { WG3. DECIMAL } \\ 71 & \text { WS3. INTEGER } \\ 76 & \text { WS3.DECIMAL } \\ 131 & \text { RS3. INTEGER } \\ 136 & \text { RS3. DECIMAL } \\ 6 & \text { DATA }\end{aligned}$

$\begin{array}{rrrr}5 & 5 & \text { I } & - \\ 1 & 1 & \mathrm{C} & - \\ 1 & 1 & \mathrm{C} & - \\ 1 & 1 & \mathrm{C} & - \\ 3 & 3 & \mathrm{C} & - \\ 4 & 4 & \mathrm{C} & - \\ 2 & 2 & \mathrm{C} & - \\ 4 & 4 & \mathrm{C} & - \\ 2 & 2 & \mathrm{C} & - \\ 4 & 4 & \mathrm{C} & - \\ 2 & 2 & \mathrm{C} & - \\ 273 & 200 & \mathrm{C} & -\end{array}$


DATAFILE NAME: IRRIGATION.COMB

38 ITEMS: STARTING IN POSITION 1 COL ITEM NAME

1 COUNTY

3 FEDID

6 YEAR

8 IRW. GWNAD3

18 IRW. GWNAD2

58 IRW. GWNAD1

63 IRW. GWNY

68 IRW. SWNAD3

78 IRW. SWNAD2

118 IRW. SWNAD1

123 IRW. SWNY

128 IRR. SWNAD3

138 IRR. SWNAD2

178 CO.ACRE.S

184 CO.ACRE.G

190 REP.ACRE.S

196 REP.ACRE.G

202 PERM.ACRE.S

208 PERM.ACRE.G

214 PONT.IRR.ACRE.S

220 PONT. IRR.ACRE.G

226 EST.ACRE.S

232 EST.ACRE.G

238 REP.WAT.S

248 REP.WAT.G

258 GAL.ACRE.S

268 GAL.ACRE.G

278 GAL.ACRE.R

WDTH OPUT TYP N.DEC ALTERNATE NAME

288

298

308

314

320

330

340

350 IN. ACRE. NORICE

EST.WAT.S

$22 \quad 2 \quad I$

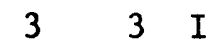

$22 \mathrm{I}$

$\begin{array}{llll}10 & 10 & \mathrm{~N} & 2\end{array}$

$4040 \quad C \quad-$

55 I

$\begin{array}{llll}5 & 5 & 1 & -\end{array}$

$10 \quad 10 \quad \mathrm{~N} \quad 2$

$4040 \quad \mathrm{C} \quad-$

$5 \quad 5$ I

$5 \quad 5$ I

$\begin{array}{llll}10 & 10 & \mathrm{~N} & 2\end{array}$

$\begin{array}{rrrr}40 & 40 & \text { C } & - \\ 6 & 6 & \text { I } & -\end{array}$

$\begin{array}{lll}6 & 6 & I\end{array}$

66 I -

66 I -

$66 \mathrm{I}-$

$\begin{array}{llll}6 & 6 & \mathrm{I} & - \\ 6 & 6 & \mathrm{~N} & 2\end{array}$

$\begin{array}{llll}6 & 6 & \mathrm{~N} & 2 \\ 6 & 6 & \mathrm{I} & -\end{array}$

$\begin{array}{rrrr}6 & 6 & \mathrm{I} & - \\ 10 & 10 & \mathrm{~N} & 2\end{array}$

$\begin{array}{llll}10 & 10 & \mathrm{~N} & 2 \\ 10 & 10 & \mathrm{~N} & 2\end{array}$

$\begin{array}{llll}10 & 10 & \mathrm{~N} & 2\end{array}$

$\begin{array}{llll}10 & 10 & \mathrm{~N} & 2\end{array}$

$\begin{array}{llll}10 & 10 & \mathrm{~N} & 2\end{array}$

$\begin{array}{llll}10 & 10 & \mathrm{~N} & 2\end{array}$

ALL.ACRE.S

ALL. ACRE.G

ALL.WAT.S

ALL.WAT. G

ALL.WAT.R

356 IN.ACRE.RICE

362 DUMMYO

** REDEFINED ITEMS

$\begin{array}{llll}10 & 10 & \mathrm{~N} & 2\end{array}$

1 ID

3 F1

4 F2

5 F3

3 F1-3

11 WG3. INTEGER

16 WG3.DECIMAL

71 WS3. INTEGER

76 WS3.DECIMAL

131 RS3. INTEGER

136 RS3.DECIMAL

6 DATA

$\begin{array}{rrrr}6 & 6 & \mathrm{I} & - \\ 6 & 6 & \mathrm{I} & - \\ 10 & 10 & \mathrm{~N} & 2 \\ 10 & 10 & \mathrm{~N} & 2 \\ 10 & 10 & \mathrm{~N} & 2 \\ 6 & 6 & \mathrm{~N} & 2 \\ 6 & 6 & \mathrm{~N} & 2 \\ 100 & 100 & \mathrm{C} & -\end{array}$

$\begin{array}{rrrr}5 & 5 & \text { I } & - \\ 1 & 1 & \text { C } & - \\ 1 & 1 & C & - \\ 1 & 1 & C & - \\ 3 & 3 & \text { C } & - \\ 4 & 4 & \text { C } & - \\ 2 & 2 & \text { C } & - \\ 4 & 4 & \text { C } & - \\ 2 & 2 & \text { C } & - \\ 4 & 4 & \text { C } & - \\ 2 & 2 & \text { C } & - \\ 273 & 200 & \text { C } & -\end{array}$


DATAFILE NAME: DOMESTIC

\begin{tabular}{|c|c|c|c|c|c|c|}
\hline col & $\begin{array}{l}\text { ITEMS: STARTING IN } \\
\text { ITEM NAME }\end{array}$ & $\begin{array}{l}\text { POSI } \\
\text { NDTH }\end{array}$ & OPUT & $\begin{array}{c}1 \\
\text { TYP }\end{array}$ & N.DEC & ALTERNATE NAME \\
\hline 1 & COUNTY & 2 & 2 & I & - & \\
\hline 3 & FEDID & 3 & 3 & I & - & \\
\hline 6 & YEAR & 2 & 2 & I & - & \\
\hline 8 & TOT.POP & 7 & 7 & I & - & \\
\hline 15 & POP.SERVE & 7 & 7 & I & - & \\
\hline 22 & DOW.GWNAD3 & 10 & 10 & $\mathrm{~N}$ & 2 & \\
\hline 32 & DOW. GWNAD2 & 40 & 40 & C & - & \\
\hline 72 & DOW.GWNAD1 & 5 & 5 & I & - & \\
\hline 77 & DOW.GWNY & 5 & 5 & I & - & \\
\hline 82 & DUMMYO & 100 & 100 & C & - & \\
\hline & ** REDEFINED ITEMS & $* x$ & & & & \\
\hline 3 & F1 & 1 & 1 & C & - & \\
\hline 4 & F2 & 1 & 1 & C & - & \\
\hline 5 & F3 & 1 & 1 & C & - & \\
\hline 3 & F1-3 & 3 & 3 & C & - & \\
\hline 25 & WG3 . INTEGER & 4 & 4 & C & - & \\
\hline 30 & WG3 . DECIMAL & 2 & 2 & C & - & \\
\hline 1 & ID & 5 & 5 & I & - & \\
\hline
\end{tabular}




\section{COUNTY AGGREGATION PROGRAMS}

The programs used as of September 5, 1985, to aggregate data by county are on the following pages. 
PROGRAM NAME: PG.MUNICIPAL

10000 PROGRAM SECTION ONE

10001 FO \$NUM1, 2, I

10002 CALC \$NUM1 $=83$

10003 SEL REPORTED. PUMPAGE

10004 RES FOR MEAS.ACC LT 6 OR MEAS.ACC GT 7

10005 REL COMMON.FILE 1 BY PERMINST\# WITH ORDERED

10006 REL WATER.USE.PERM 2 BY PERMIT\# WITH ORDERED

10007 REL MUNICIPAL 3 BY \$1COUNTY WITH ORDERED

20000 PROGRAM SELECTION 2

20001 IF REP. YR EQ \$NUM1

20002 IF \$IUSE.CODE GE 10 AND \$IUSE.CODE LE 16

20003

20004

20005

20006

20007

20008

20009

20010

20011

20012

20013

20014

20015

20016

20017

20018

20019

20020

30000

30001

30002

30003

30004

30005

40000

IF \$1RESOURCE. CODE CN ' 1 '

IF MEAS.ACC NE 5

CALC $\$ 3 W S W . G W R V=\$ 3 W S W . G W R V+A N . V O L . A P P R O P$

CALC \$3WSW.GWNAD1 $=$ \$3WSW.GWNAD $1+1$

ELSE

CALC \$3WSW.GWEV = \$3WSW.GWEV + AN.VOL.APPROP

CALC \$3WSW.GWEI $=\$ 3 W W$. GWEI +1

ENDIF

ELSE

IF MEAS.ACC NE 5

CALC \$3WSW.SWRV = \$3WSW.SWRV + AN.VOL.APPROP

CALC \$3WSW. SWNAD1 $=$ \$3WW. SWNAD1 +1

ELSE

CALC \$3WSW. SWEV $=\$ 3 W S W$. SWEV + AN. VOL. APPROP

CALC \$3WSW. SWEI $=$ \$3WW. SWEI +1

ENDIF

ENDIF

ENDIF

PROGRAM SECTION 3

SEL MUNICIPAL

CALC WSW.GWNAD3 = WSW.GWRV + WSW.GWEV

CALC WSW. GWNY = WSW.GWNAD1 + WSW.GWEI

CALC WSW. SWNAD3 = WSW.SWRV + WSW. SWEV

CALC WSW. SWNY $=$ WSW. SWNAD $1+$ WSW.SWEI

PROGRAM SECTION 
PROGRAM NAME: PG.MUNNIES

10000 PROGRAM SECTION ONE

10002 FO \$NUM1, 2, I

10002 CALC \$NUM1 $=83$

10003 SEL REPORTED. PUMPAGE

10004 RES FOE MEAS.ACC LT 6 OR MEAS.ACC GT 7

10005 REL COMMON.FILE 1 BY PERMINST\# WITH ORDERED

10006 REL WATER.USE. PERM 2 BY PERMIT\# WITH ORDERED

10007 REL MUNNIES 3 BY \$1COUNTY WITH ORDERED

20000 PROGRAM SECTION 2

20001 IF REP.YR EQ \$NUM1

20002 IF \$IUSE.CODE EQ 11

20003 IF \$IRESOURCE. CODE CN ' 1 '

20004 IF MEAS.ACC NE 5

20005

CALC \$3MUW. GWRV = \$3MUW.GWRV + AN. VOL.APPROP

20006

CALC \$3MUW. GWNAD1 = \$3MUW. GWNAD1 + 1

20007

ELSE

20008

CALC \$3MUW. GWEV $=\$ 3 M U W$. GWEV + AN. VOL. APPROP

20009

CALC \$3MUW. GWEI $=$ \$3MUW. GWEI +1

20010

20011 ENDIF

20012

ELSE

20013

IF MEAS.ACC NE 5

20014

CALC \$3MUW.SWRV $=$ \$3MUW.SWRV + AN.VOL.APPROP

20015

CALC \$3MUW. SWNAD1 $=\$ 3 M U W$. SWNAD $1+1$

20016

ELSE

20017

20018

20019

20020

20021 ENDIF

30000 PROGRAM SECTION 3

30001 SEL MUNNIES

30002 CALC MUW. GWNAD3 = MUW.GWRV + MUW. GWEV

30003 CALC MUW. GWNY $=$ MUW. GWNAD1 + MUW. GWEI

30004 CALC MUW.SWNAD3 $=$ MUW.SWEV + MUW.SWEV

30005 CALC MUW. SWNY $=$ MUW. SWNAD1 + MUW. SWEI

40000 PROGRAM SECTION 4

50000 PROGRAM SECTION 5

50001 FO \$NUM1, 6, I

50002 SEL REPORTED. PUMPAGE

50003 RES FOR REP. YR EQ 83

50004 RES FOR MEAS.ACC LT 6 OR MEAS.ACC GT 7

50005 CALC $\$ N M=1$

50006 REL COMMON.FILE 1 BY PERMIT\# ORDERED

50007 REL MUNNIES 2 BY \$1COUNTY ORDERED

50008 REL MUNICIPAL 3 BY \$2COUNTY ORDERED

50009 REL WATER.USE. PERM 4 BY PERMIT\# ORDERED

50010 CALC $\$ N U M 1=0$

60000 PROGRAM SECTION 6

60001 IF $($ \$NUM1 = PERMIT\# $)$

$60002 \quad$ CALC REP.YR $=38$

60003 ELSE

$60004 \quad$ CALC $\$$ NUMI $=$ PERMIT\# 


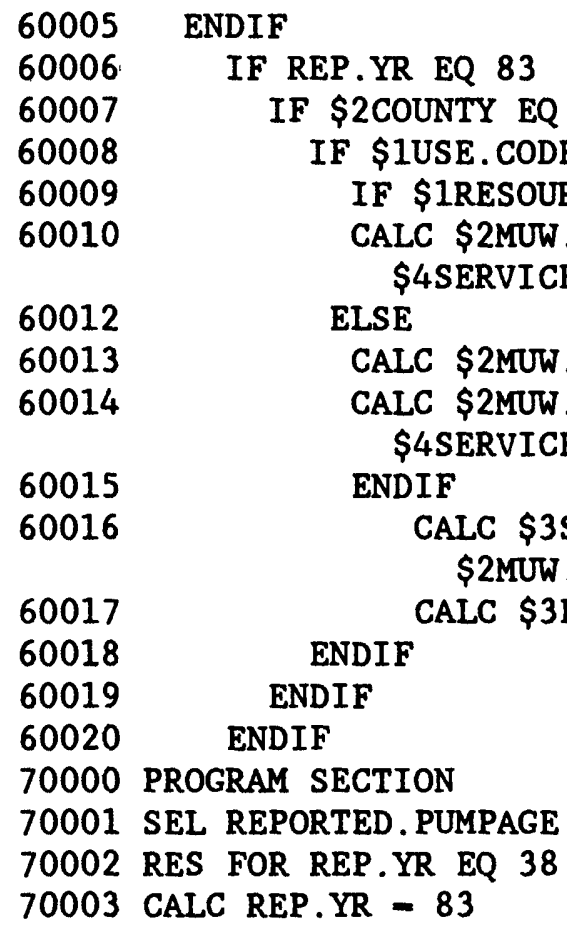


PROGRAM NAME: PG. WAWO

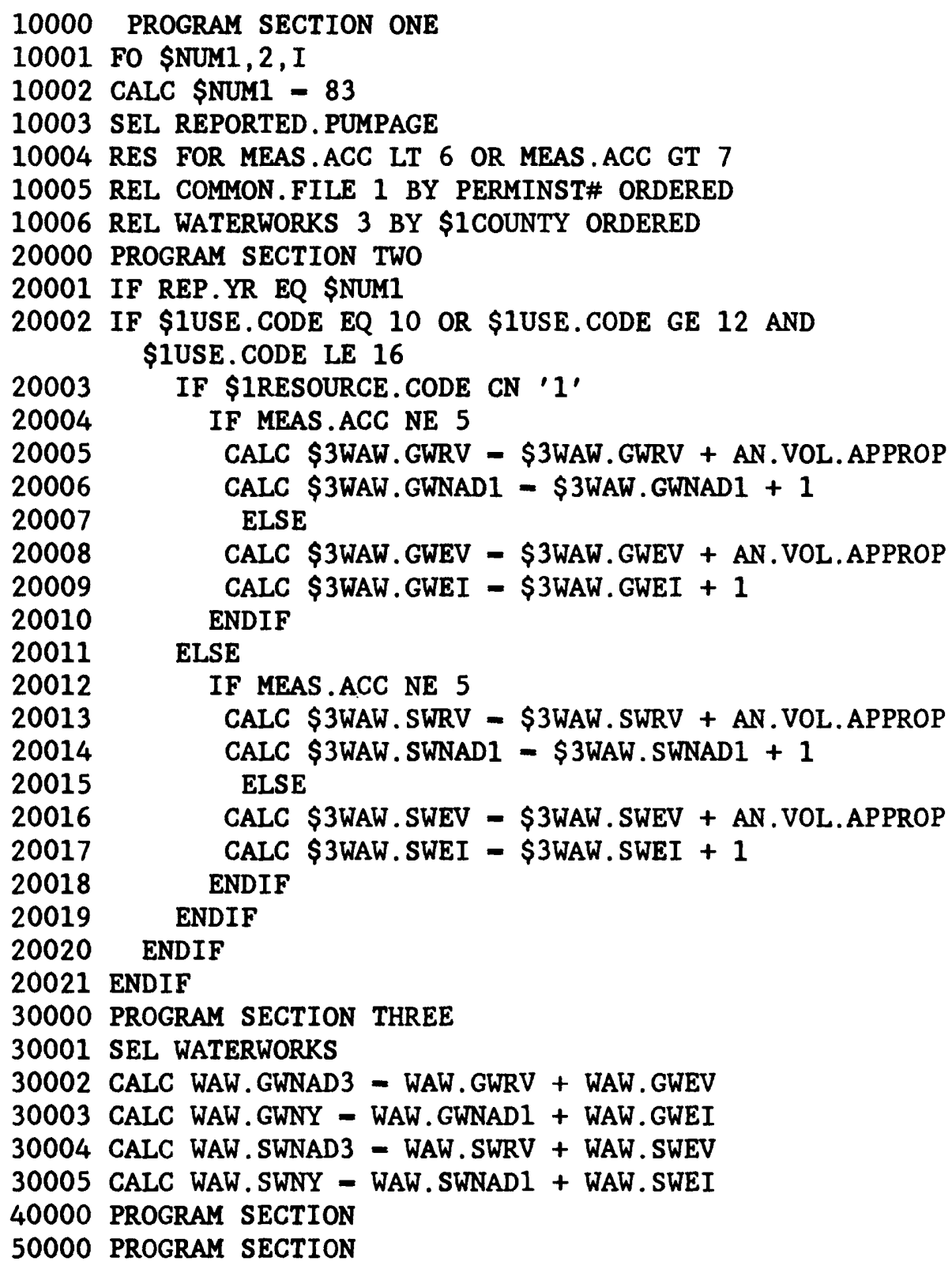


PROGRAM NAME: PG.COMMERCIAL

10000 PROGRAM SECTION ONE

10001 FORMAT \$NUM1,2, I REP.YR

10002 CALC \$NM - 1

10003 CALC \$NUM1 - 83

10004 SEL REPORTED. PUMPAGE

10005 RES FOR MEAS.ACC LT 6 OR MEAS.ACC GT 7

10006 REL COMMON.FILE 1 BY PERMINST\# WITH ORDERED

10007 REL COMMERCIAL 2 BY \$1COUNTY WITH ORDERED

20000 PROGRAM SECTION 2

20001 IF REP.YR EQ \$NUM1

20002 IF \$1USE.CODE GE 30 AND \$1USE.CODE LT 40

20003

IF \$IRESOURCE. CODE CN ' 1 '

20004

IF MEAS. ACC NE 5

20005

CALC \$2COW.GWRV = \$2COW.GWRV + AN. VOL.APPROP

20006

20007

20008

20009

20010

20011

20012

20013

20014

20015

20016

20017

20018

20019

20020

20021

20022

20023

20024

20025

CALC \$2COR. SWNAD3 $=\$ 2 C O R$. SWNAD3 + AN.DISCH

CALC \$COW.GWNAD1 = \$COW.GWNAD1 + 1

ELSE

CALC $\$ 2 C O W$. GWEV $=\$ 2 C O W . G W E V+$ AN.VOL.APPROP

CALC \$2COW. GWEI $=\$ 2$ COW.GWEI +1

CALC $\$ 2$ COR. SWNAD3 $=\$ 2 C O R$. SWNAD3 + AN.DISCH

ENDIF

IF AN.DISCH NE 0

CALC \$2COR. SWNAD1 $=\$ 2$ COR. SWNAD1 +1

CALC \$2COR. SWNY $=\$ 2$ COR. SWNY +1

ENDIF

ELSE

IF MEAS. ACC NE 5

CALC \$2COW. SWRV $=\$ 2 \mathrm{COW} . \mathrm{SWRV}+$ AN. VOL. APPROP

CALC \$2COR. SWNAD3 $=\$ 2 C O R$. SWNAD3 + AN.DISCH

ELSE

CALC \$2COW. SWNAD1 $=$ \$2COW. SWNAD1 +1

20026

20027

20028

20029

20030

20031

20032

30000

30001

30002 CALC COW.GWNAD3 $=$ COW.GWRV + COW.GWEV

30003 CALC COW. GWNY = COW.GWNAD1 + COW.GWEI

30004 CALC COW. SWNAD $3=$ COW.SWRV + COW. SWEV

30005 CALC COW. SWNY $=$ COW.SWNAD $1+$ COW.SWEI 
PROGRAM NAME: PG. INDUSTRYY

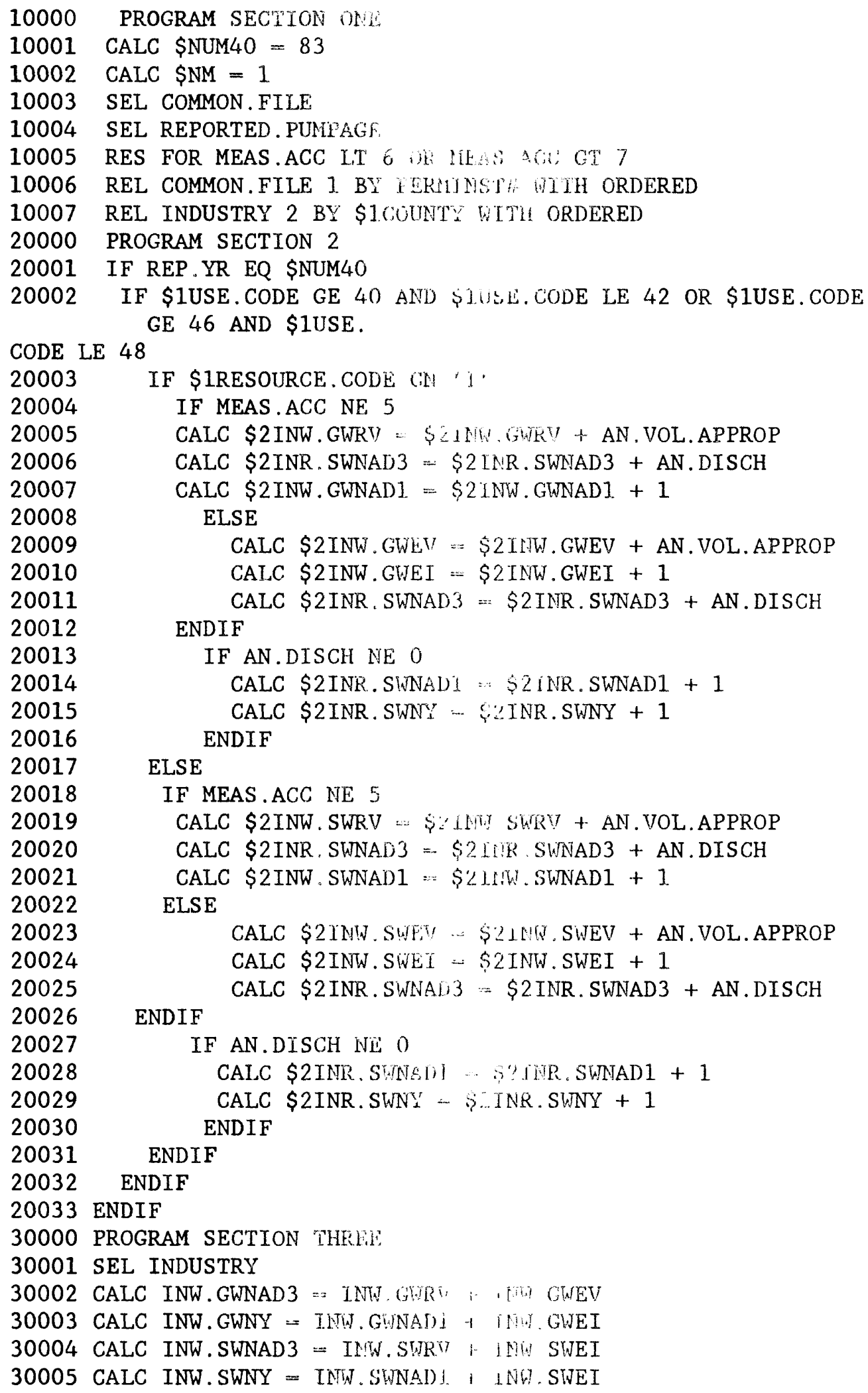




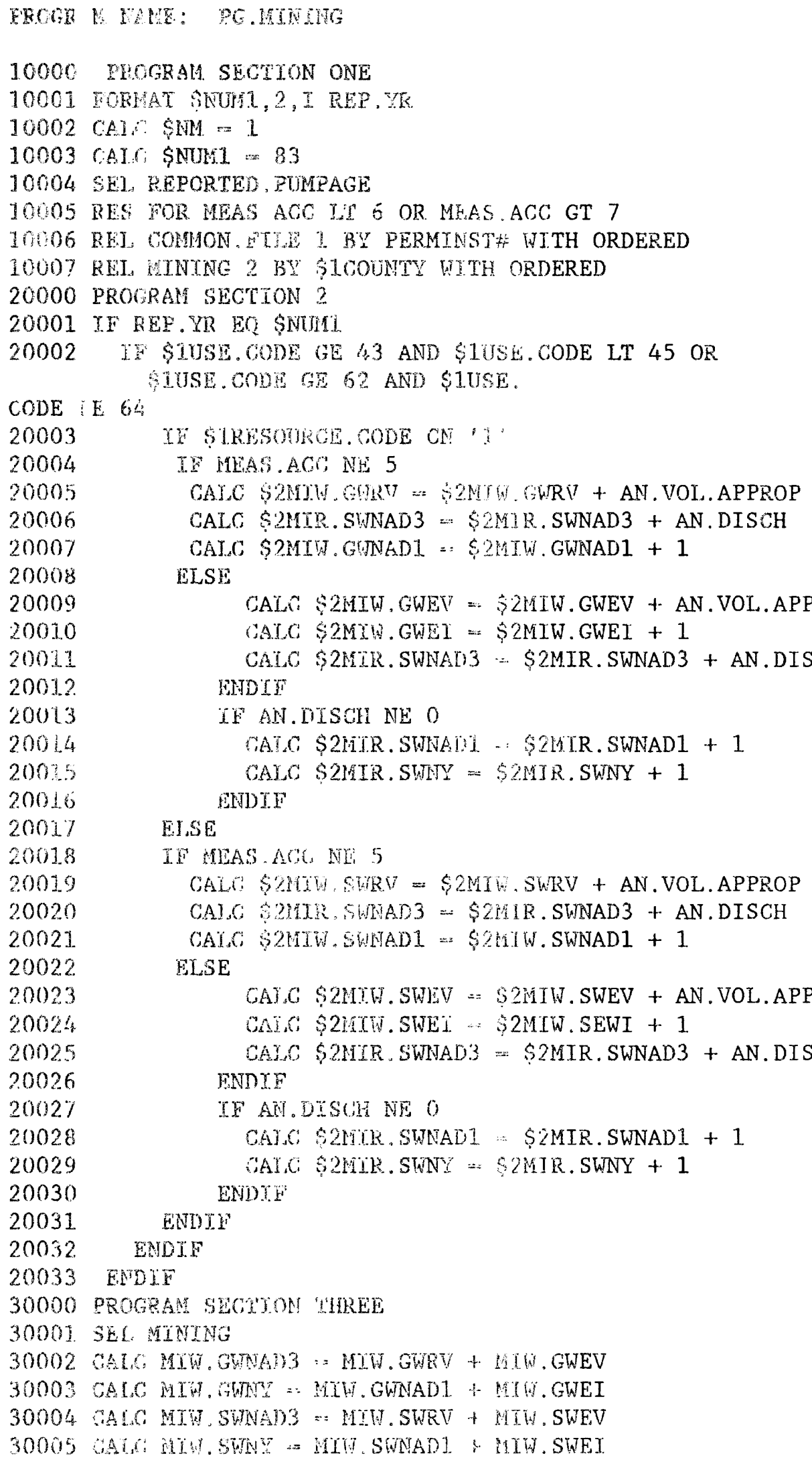


PROGRAM NAME: PG.FOSSIL

10000 PROGRAM SECTION ONE

10001 FORMAT \$NUM1, 2, I REP.YR

10002 CALC $\$ N M=1$

10003 CALC $\$$ NUM1 $=83$

10004 SEL REPORTED. PUMPAGE

10005 RES FOR MEAS.ACC LT 6 OR MEAS.ACC GT 7

10006 REL COMMON.FILE 1 BY PERMINST\# WITH ORDERED

10007 REL FOSSIL 2 BY \$1COUNTY WITH ORDERED

20000 PROGRAM SECTION 2

20001 IF REP.YR EQ \$NUM1

20002 IF \$1USE.CODE EQ 20 OR \$1USE.CODE GE 22 AND \$IUSE. CODE LT 30

20003 IF \$1RESOURCE. CODE CN ' 1 '

20004 IF MEAS.ACC NE 5

20005

CALC \$2PFW.GWRV = \$2PFW.GWRV + AN.VOL.APPROP

20006

CALC \$2PFR. SWNAD3 = \$2PFR. SWNAD3 + AN.DISCH

20007

CALC \$2PFW. GWNAD1 $=$ \$2PFW. GWNAD1 +1

20008

ELSE

20009

20010

20011

20012

20013

20014

20015

20016

20017

20018

20019

20020

20021

20022

20023

20024

20025

20026

20027

20028

20029

20030

20031

20032

20033 ENDIF

30000 PROGRAM SECTION ONE

30001 SEL FOSSIL

30002 CALC PFW.GWNAD3 = PFW.GWRV + PFW.GWEV

30003 CALC PFW. GWNY = PFW.GWNAD1 + PFW. GWEI

30004 CALC PFW. SWNAD3 = PFW. SWRV + PFW. SWEV

30005 CALC PFW. SWNY = PFW. SWNAD $1+$ PFW. SWEI 


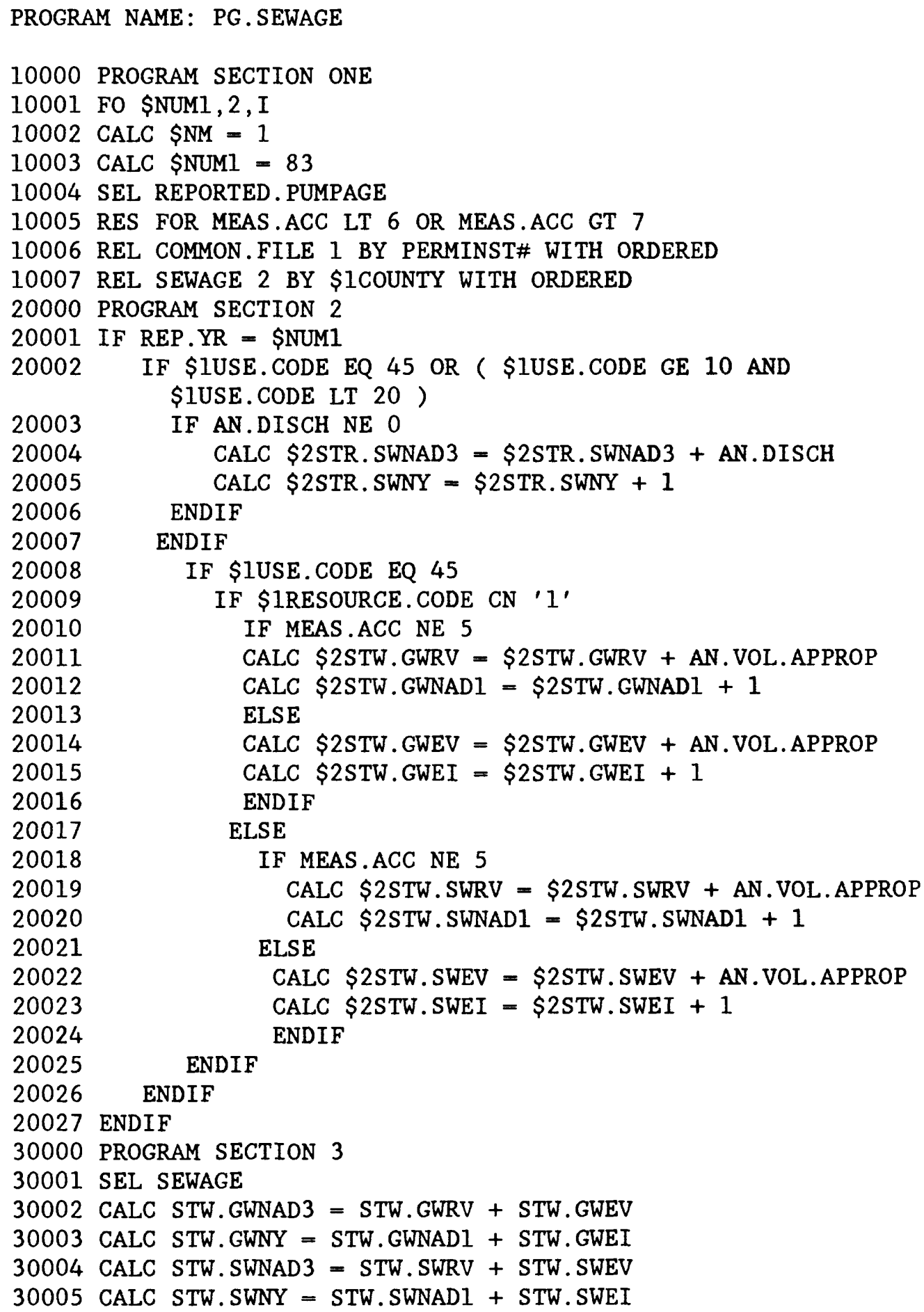


PROGRAM NAME: PG.IRR.RICE

10000 PROGRAM SECTION ONE

10001 FO \$NUM1,2, I

10002 FOR \$NUM1,2,I

10003 FOR \$NUM $3,6, I$

10004 CALC \$NUM1 $=83$

10005 CALC $\$ N M=1$

10006 SEL WATER.USE. PERM

10007 RES FOR TERM. YEAR EQ 0 OR TERM. YEAR GT 83

10008 REL COMMON.FILE 1 BY PERMIT\# ORDERED

10010 RES FOR \$1USE.CODE EQ 96

20000 PROGRAM SECTION 2

20001

20002

IF \$1RESOURCE. CODE CN ' 1 '

20003

20004

CALC $\$ 2$ CO.ACRE.G $=\$ 2$ CO. ACRE.G + TOT. ACRE ELSE

CALC $\$ 2$ IRW.GWNY $=\$ 2$ IRW.GWNY +1

20005

20006

20007

CALC $\$ 2$ IRW. SWNY $=\$ 2$ IRW.SWNY +1 ENDIF

CALC $\$ 2$ CO. ACRE.S $=\$ 2$ CO.ACRE.S + TOT.ACRE

30000 PROGRAM SECTION 3

30001 SEL WATER.USE. PERM

30002 REL COMMON. FILE 1 BY PERMIT\# ORDERED

30003 REL REPORTED. PUMPAGE 2 BY PERMIT\# ORDERED

30004 REL IRRIGATION 3 BY \$1COUNTY ORDERED

30005 RES FOR \$1USE. CODE EQ 96

40000 PROGRAM SECTION 4

40001 IF \$2CROP.ACRE1 NE 0 AND \$REP.YR EQ 83

40002 IF \$1RESOURCE. CODE CN ' 1 '

40003 CALC \$3PERM.ACRE.G = \$3PERM.ACRE.G + TOT.ACRE

40004

40005

40006

40007

40008

40009

40010

40011 ENDIF

50000 PROGRAM SECTION 5

50001 SEL REPORTED. PUMPAGE

50002 RES FOR REP.YR EQ 83

50003 REL COMMON. FILE 1 BY PERMINST\# ORDERED

50004 REL IRRIGATION 2 BY \$1COUNTY ORDERED

50005 RES FOR CROP.ACRE1 GT 0

50006 RES FOR \$1USE. CODE EQ 96

60000 PROGRAM SECTION 4

60001

60002

IF \$1RESOURCE. CODE CN ' 1 '

CALC \$2REP.ACRE.G = \$2REP.ACRE.G + CROP.ACRE1 + CROP.ACRE2 + CROP.ACRE3

60003 IF \$2PERM.ACRE.G GT 0

60004

60005

CALC \$2PCNT.IRR. ACRE.G = \$2REP.ACRE.G / \$2PERM.ACRE.G

ENDIF 


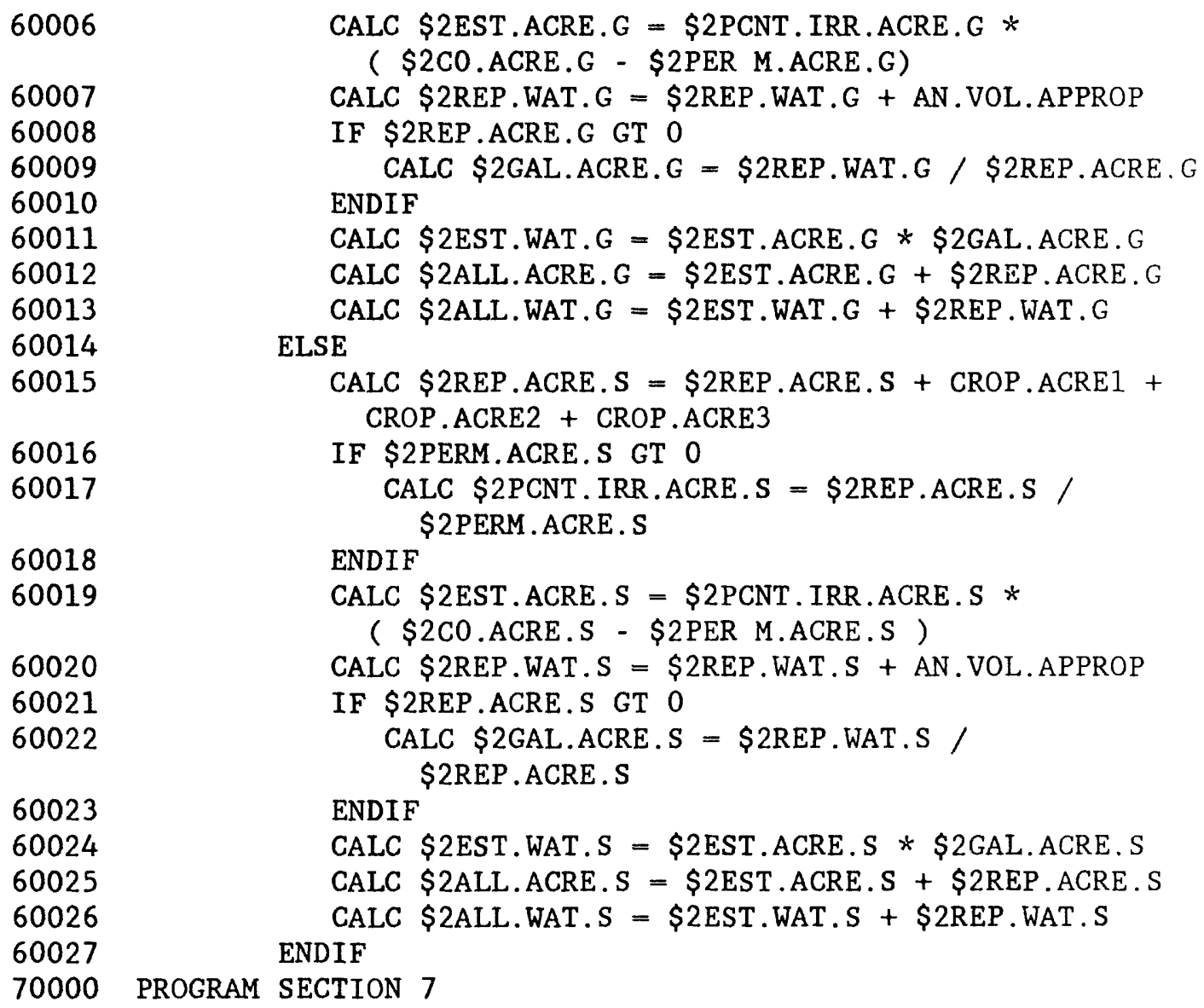


PROGRAM NAME: PG.IRR. NORICE

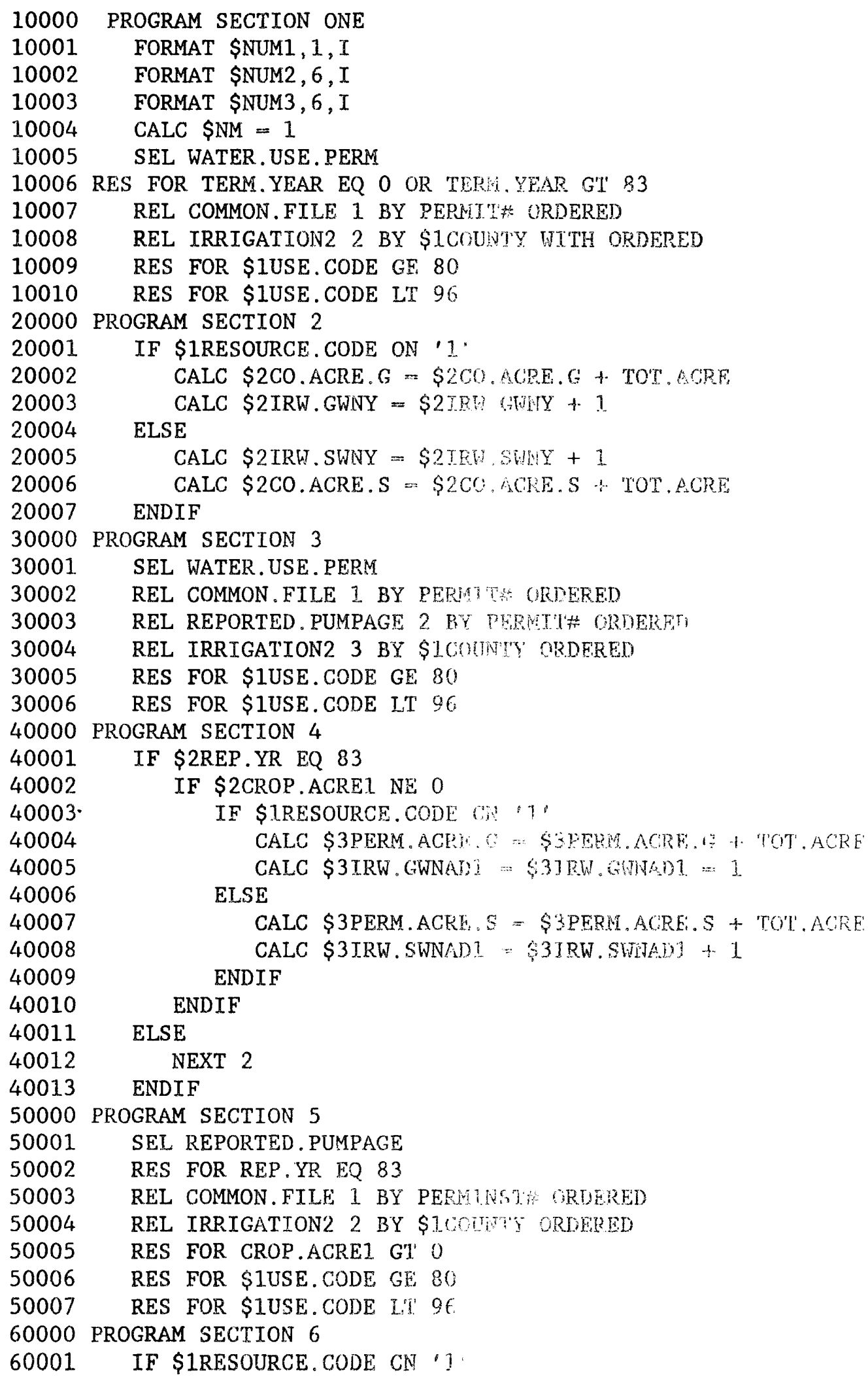




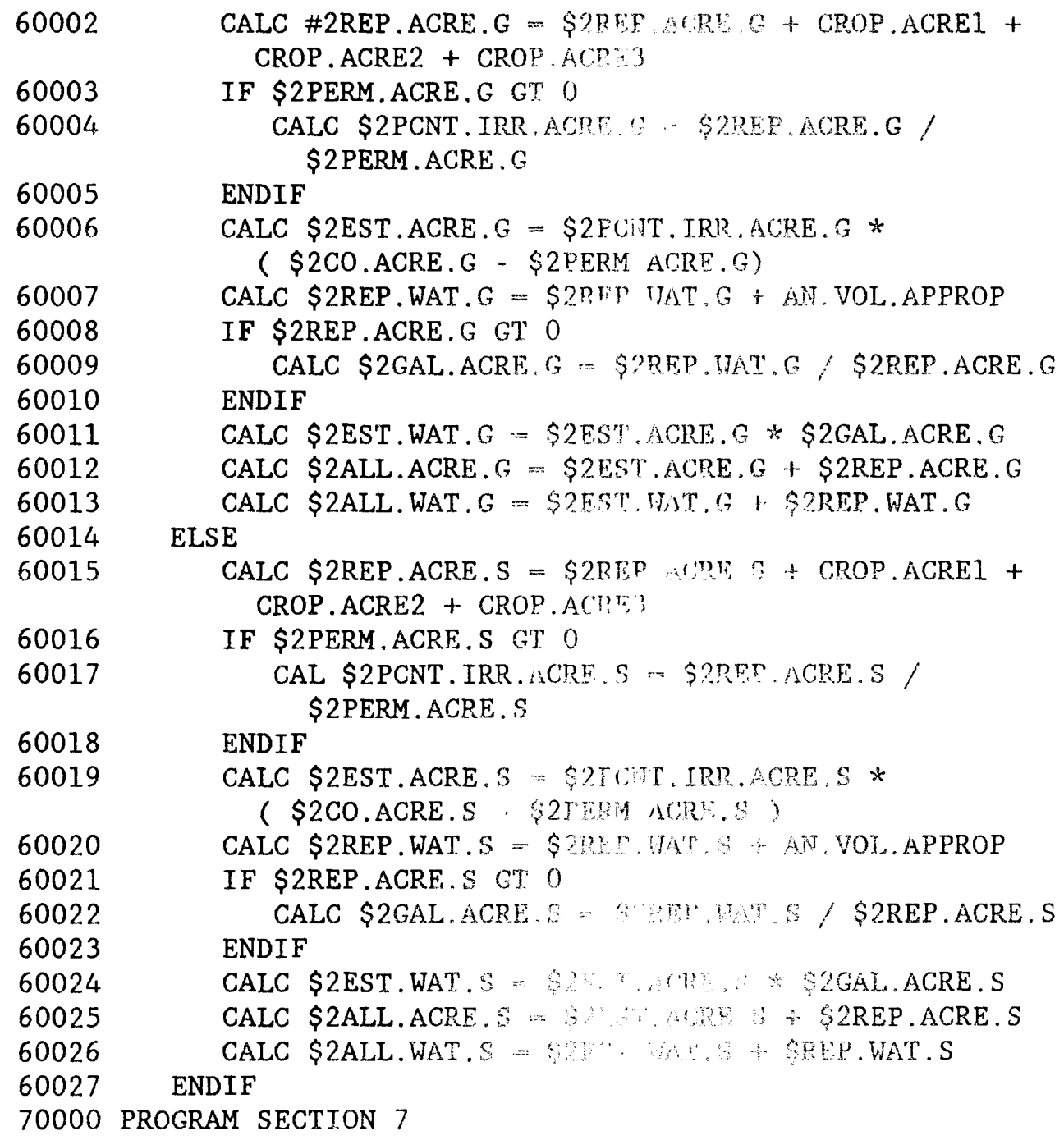


PROGRAM NAME: PG. IRR. COMBINE

10000 PROGRAM SECTION ONE

10001 SEL IRRIGATION. COMB

10002 REL IRRIGATION BY COUNTY ORDERED

10003 REL IRRIGATION2 2 BY COUNTY ORDERED

20000 PROGRAM SECTION 2

20001 CALC CO.ACRE.S $=\$ 1$ CO.ACRE.S + \$2CO.ACRE.S

20002 CALC CO.ACRE.G $=\$ 1$ CO.ACRE.G + 2 CO.ACRE.G

20003 CALC REP.ACRE.S $=$ \$1REP.ACRE.S + \$2REP.ACRE.S

20004 CALC REP.ACRE.G + \$1REP.ACRE.G + \$2REP.ACRE.G

20005 CALC PERM.ACRE.S + \$1PERM.ACRE.S + \$2PERM.ACRE.S

20006 CALC PERM.ACRE.G = \$1PERM.ACRE.G + \$2PERM.ACRE.G

20007 CALC PCNT. IRR. ACRE.S = REP.ACRE.S / PERM.ACRE.S

20008 CALC PCNT.IRR.ACRE.G = REP.ACRE.G / PERM.ACRE.G

20009 CALC EST.ACRE.S = PCNT.IRR.ACRE.S * ( CO.ACRE.S PERM.ACRE.S )

20010 CALC EST.ACRE.G = PCNT.IRR.ACRE.G * ( CO.ACRE.G PERM.ACRE.G )

20011 CALC REP.WAT.S = \$1REP.WAT.S + \$2REP.WAT.S

20012 CALC REP.WAT.G = \$1REP.WAT.G + \$2REP.WAT.G

20013 CALC GAL.ACRE.S = REP.WAT.S / REP.ACRE.S

20014 CALC GAL.ACRE.G = REP.WAT.G / REP.ACRE.G

20015 CALC EST.WAT.S = EST.ACRE.S * GAL.ACRE.S

20016 CALC EST.WAT.G = EST.ACRE.G * GAL.ACRE.G

20017 CALC ALL.ACRE.S = EST.ACRE.S + REP.ACRE.S

20018 CALC ALL.ACRE.G = EST.ACRE.G + REP.ACRE.G

20019 CALC ALL.WAT.S = EST.WAT.S + REP.WAT.S

20020 CALC ALL.WAT.G = EST.WAT.G + REP.WAT.G

20021 CALC IN.ACRE.RICE = ( (\$1GAL.ACRE.S + \$1GAL.ACRE.G ) / $0.326) * 12$

20022 CALC IN.ACRE. NORICE $=$ ( ( \$2GAL.ACRE.S + \$2GAL.ACRE.G ) / $0.326) * 12$

20023 CALC ALL.WAT.R = \$1ALL.WAT.S + \$1ALL.WAT.G

20024 MOVE \$11RW. GWNAD2 TO IRW.GWNAD2

20025 MOVE \$11RW. SWNAD2 TO IRW. SWNAD2

20026 MOVE \$11RR. SWNAD2 TO IRR. SWNAD2

20027 CALC IRW.GWNAD1 = \$1IRR.GWNAD1 + \$2IRW.GWNAD1

20028 CALC IRW. SWNAD1 $=$ \$1IRW. SWNAD1 + \$2IRW. SWNAD1

20029 CALC IRW. GWNAD3 = \$1IRW.GWNAD3 + \$2IRW.GWNAD3

20030 CALC IRW. SWNAD $3=$ \$1IRW. SWNAD3 + \$2IRW. SWNAD3

20031 CALC IRW.GWNY $=$ \$IIRW.GWNY + \$2IRW.GWNY

20032 CALC IRW.SWNY = \$IIRW.SWNY + \$2IRW.SWNY

30000 PROGRAM SECTION ONE 
PROGRAM NAME: PG.DOMESTIC

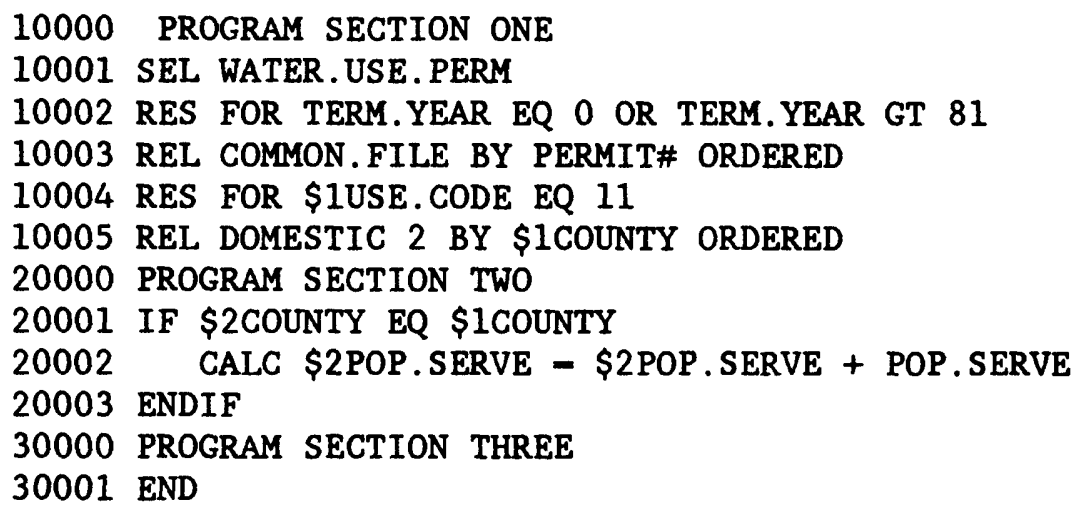

PROGRAM NAME: PG.FINAL.DOMESTIC

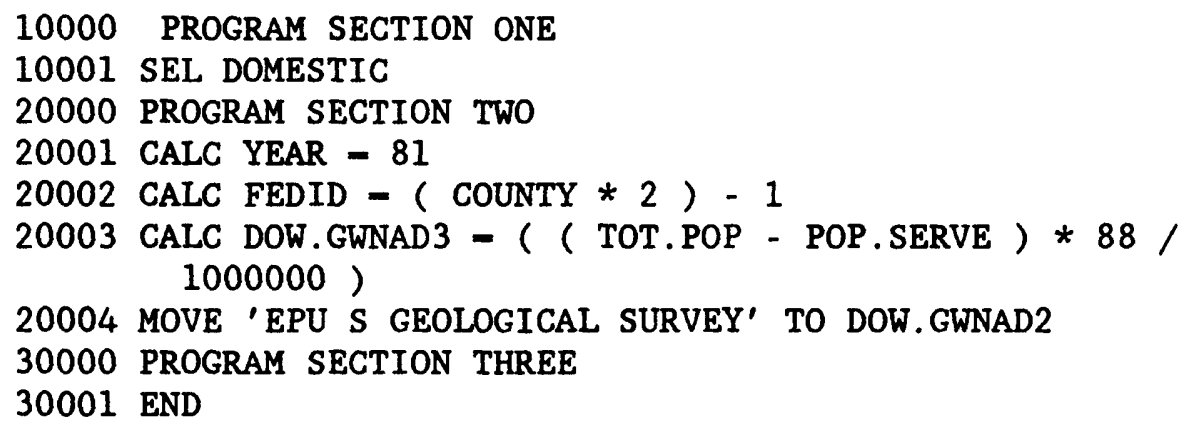

PROGRAM NAME: PG.REPORT.DOMESTIC

10000 PROGRAM SECTION ONE

10001 SEL DOMESTIC

10002 RES FOR F1 CN ' '

10003 MOVE 'O' TO F1

10004 ASEL

10005 RES FOR F2 CN ' '

10006 MOVE ' 0 ' TO F2

10007 ASEL

10008 OUTPUT R.DOMESTIC. 81 INIT

20000 PROGRAM SECTION TWO

20001 PRINT 1T, '4USGS 27',F1-3,5X, 'DOW GWNAD3', 28T, WG3. INTEGER, 32T, WG3. DECIMAL

20002 PRINT 1T, '4USGS 27',F1-3,5X,'DOW GWNAD2', DOW. GWNAD2

20003 PRINT 1T, '4USGS $27^{\prime}, \mathrm{Fl}-3,5 \mathrm{X}$, 'DOW GWNAD1', DOW. GWNADI, 'NY', DOW. GWNY

20004 PRINT 1T,'4USGS 27',F1-3,5X,'DO AP1DO', POP.SERVE

30000 PROGRAM SECTION THREE

30001 END 
The datafile structure, as of September 5, 1985, for each of the watershed aggregation datafiles is shown on the following pages. For each of the items in the datafiles the following characteristics are given:

COL-- The starting column for the item.

ITEM NAME--The name of the item.

WDTH--The width of the item in the file.

OPUT--The number of spaces needed to display or print the item values.

TYP--The item type:

C--Character; the letters of the alphabet, punctuation, and numbers that are not numberic values.

I--Integer; numbers without decimal places.

$\mathrm{N}$--Numeric; numbers that can have decimal places.

D--Date; month, day, and year.

$N$. Dec--The number of decimal places if the item is numeric.

ALTERNATE NAME--An alternate name to be used for the item if one exists.

Redefined items are used to change the datafile templates to fit changing data needs. A redefined item can specify a combination of adjacent items or a subset of an item or items. The characteristics for the redefined items follow the characteristics for the items. 
DATAFILE NAME: WSW

22 ITEMS: STARTING IN POSITION 1

COL ITEM NAME

1 WATSHD. UNIT

3 FEDID

11 YEAR

13 WSW. GWNAD3

23 WSW. GWNAD2

63 WSW.GWNAD1

68 WSW. GWNY

73 WSW. SWNAD3

83 WSW.SWNAD2

123 WSW. SWNAD1

128 WSW. SWNY

133 WSW.GWRV

143 WSW.GWEV

153 WSW.GWEI

158 WSW.SWRV

168 WSW. SWEV

178 WSW.SWEI

183 WSW.POP

190 WSW.CONNECTIONS

197 DUMMYO

297 SERVICE.CONN

304 POP.SERVE

** REDEFINED ITEMS

1 ID

3 F1

3 W1 $=8$

4 F2

5 F3

3 F1-3

16 WG3. INTEGER

21 WG3.DECIMAL

76 WS3. INTEGER

81 WS3.DECIMAL

6 DATA
WDTH OPUT TYP N.DEC ALTERNATE NAME

$\begin{array}{llll}2 & 2 & I & - \\ 8 & 8 & I & -\end{array}$

$\begin{array}{llll}2 & 2 & I & -\end{array}$

$\begin{array}{llll}10 & 10 & \mathrm{~N} & 2\end{array}$

4040 C -

555 I -

$\begin{array}{llll}5 & 5 & \mathrm{I} & -\end{array}$

$\begin{array}{llll}10 & 10 & \mathrm{~N} & 2\end{array}$

4040 C -

55 I -

55 I -

$\begin{array}{llll}10 & 10 & \mathrm{~N} & 2\end{array}$

$\begin{array}{llll}10 & 10 & \mathrm{~N} & 2\end{array}$

55 I -

$\begin{array}{llll}10 & 10 & \mathrm{~N} & 2\end{array}$

$1010 \mathrm{~N} 2$

55 I -

$\begin{array}{lll}7 & 7 & I \\ 7 & 7 & \text { - }\end{array}$

$100100 \mathrm{C}$ -

$\begin{array}{llll}7 & 7 & I \\ 7 & 7 & \text { - }\end{array}$

** $7 \mathrm{I}$

$\begin{array}{llll}10 & 10 & I\end{array}$

$\begin{array}{llll}1 & 1 & C & - \\ 8 & 8 & C & -\end{array}$

$88 \mathrm{C}$ -

$\begin{array}{llll}1 & 1 & \mathrm{C} & - \\ 1 & 1 & \mathrm{C} & -\end{array}$

33 C -

44 C -

$22 \mathrm{C}$ -

44 C -

$\begin{array}{rrrr}2 & 2 & C & - \\ 273 & 200 & C & -\end{array}$ 
DATAFILE NAME: WMU

24 ITEMS: STARTING IN POSITION 1

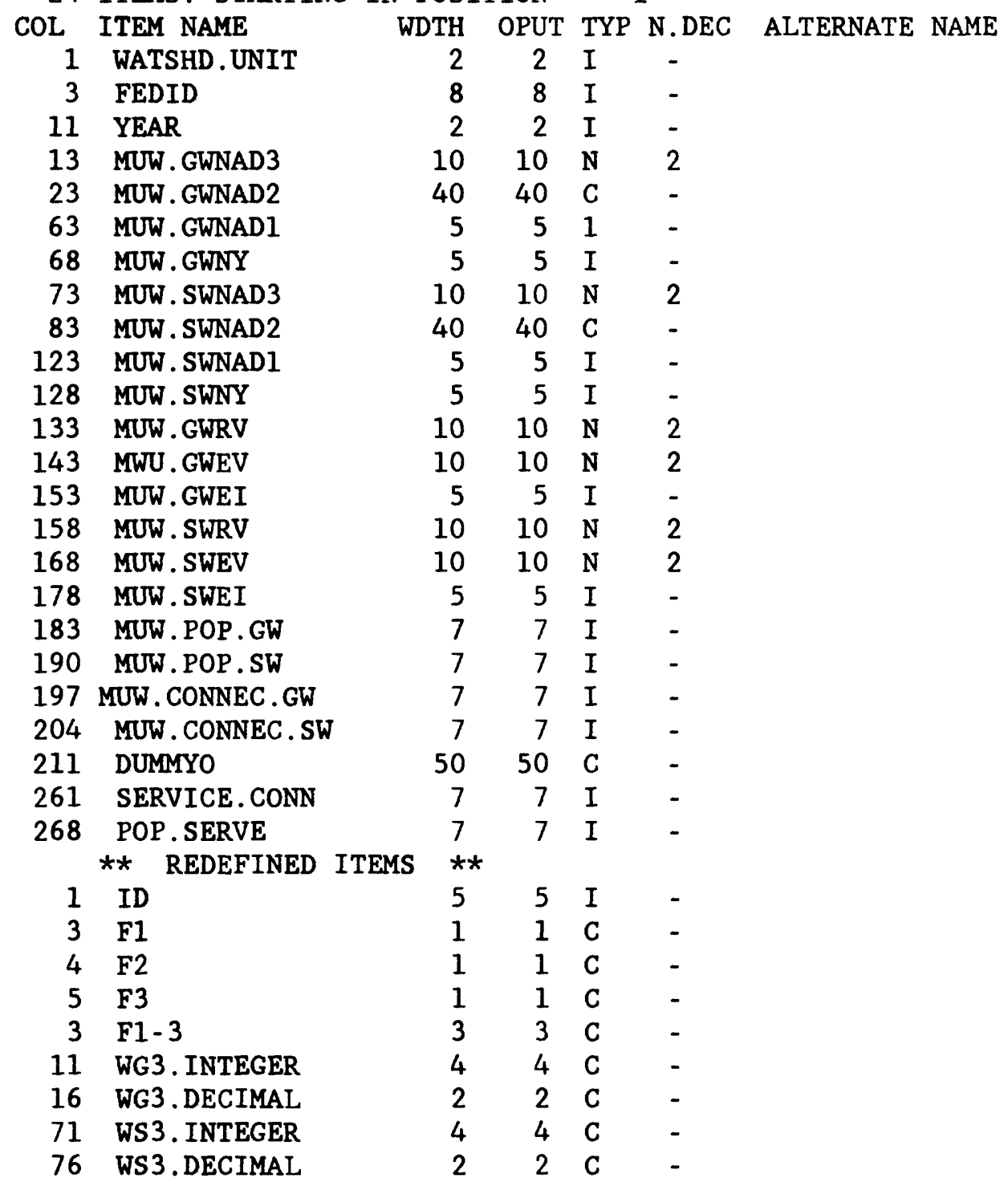


DATAFILE NAME: WAW

18 ITEMS: STARTING IN POSITION 1 COL ITEM NAME

1 WATSHD. UNIT

3 FEDID

11 YEAR

13 WAW. GWNAD3

23 WAW. GWNAD2

63 WAW. GWNAD1

68 WAW. GWNY

73 WAW. SWNAD3

83 WAW. SWNAD2

123 WAW. SWNAD1

128 WAW. SWNY

133 WAW.GWRV

143 WAW.GWEV

153 WAW.GWEI

158 WAW. SWRV

168 WAW. SWEV

178 WAW. SWEI

WDTH OPUT TYP N.DEC ALTERNATE NAME

183 DUMMYO

$\begin{array}{llll}2 & 2 & \text { I } & - \\ 8 & 8 & \text { I } & -\end{array}$

22 I -

$\begin{array}{llll}10 & 10 & \mathrm{~N} & 2\end{array}$

4040 C -

55 I -

$55 \mathrm{I}$ -

$\begin{array}{llll}10 & 10 & \mathrm{~N} & 2\end{array}$

4040 C -

55 I -

$55 \mathrm{I}$ -

$10 \quad 10 \mathrm{~N} \quad 2$

$\begin{array}{llll}10 & 10 & \mathrm{~N} & 2\end{array}$

$55 \mathrm{I}$ -

$10 \quad 10 \mathrm{~N} \quad 2$

$1010 \mathrm{~N} 2$

$55 \mathrm{I}$ -

** REDEFINED ITEMS ** 50 C -

$\begin{array}{rlllll}1 & \text { ID } & 5 & 5 & \text { I } & - \\ 3 & \text { F1 } & 1 & 1 & C & - \\ 4 & \text { F2 } & 1 & 1 & \text { C } & - \\ 5 & \text { F3 } & 1 & 1 & \text { C } & - \\ 3 & \text { F1-3 } & 3 & 3 & \mathrm{C} & - \\ 11 & \text { WG3. INTEGER } & 4 & 4 & \mathrm{C} & - \\ 16 & \text { WG3.DECIMAL } & 2 & 2 & \mathrm{C} & - \\ 71 & \text { WS3. INTEGER } & 4 & 4 & \mathrm{C} & - \\ 76 & \text { WS3.DECIMAL } & 2 & 2 & \mathrm{C} & -\end{array}$


DATAFILE NAME: WCO

\begin{tabular}{|c|c|c|c|c|c|c|}
\hline 22 & ITEMS: STARTING & G IN POSI & ITION & & 1 & \\
\hline $\mathrm{COL}$ & ITEM NAME & WDTH & OPUT & TYP & N.DEC & ALTERNATE NAME \\
\hline 1 & WATSHD. UNIT & 2 & 2 & I & - & \\
\hline 3 & FEDID & 8 & 8 & I & - & \\
\hline 11 & YEAR & 2 & 2 & I & - & \\
\hline 13 & COW. GWNAD3 & 10 & 10 & $\mathrm{~N}$ & 2 & \\
\hline 23 & COW. GWNAD2 & 40 & 40 & C & - & \\
\hline 63 & COW.GWNAD1 & 5 & 5 & I & - & \\
\hline 68 & COW. GWNY & 5 & 5 & $I$ & - & \\
\hline 73 & COW. SWNAD3 & 10 & 10 & $\mathbf{N}$ & 2 & \\
\hline 83 & COW. SWNAD2 & 40 & 40 & C & - & \\
\hline 123 & COW. SWNADI & 5 & 5 & I & - & \\
\hline 128 & COW. SWNY & 5 & 5 & I & - & \\
\hline 133 & COR. SWNAD3 & 10 & 10 & $\mathrm{~N}$ & 2 & \\
\hline 143 & COR. SWNAD2 & 40 & 40 & C & - & \\
\hline 183 & COR.SWNAD1 & 5 & 5 & I & - & \\
\hline 188 & COR. SWNY & 5 & 5 & I & - & \\
\hline 193 & COW.GWRV & 10 & 10 & $\mathbf{N}$ & 2 & \\
\hline 203 & COW.GWEV & 10 & 10 & $\mathbf{N}$ & 2 & \\
\hline 213 & COW.GWEI & 5 & 5 & I & - & \\
\hline 218 & COW. SWRV & 10 & 10 & $\mathbf{N}$ & 2 & \\
\hline 228 & COW. SWEV & 10 & 10 & $\mathbf{N}$ & 2 & \\
\hline 238 & COW. SWEI & 5 & 5 & I & - & \\
\hline 243 & DUMMYO & 100 & 100 & C & - & \\
\hline & $\star * \quad$ REDEFINED I & ITEMS & & & & \\
\hline 3 & F1 & 1 & 1 & C & - & \\
\hline 3 & WI - 8 & 8 & 8 & C & - & \\
\hline 4 & F2 & 1 & 1 & C & - & \\
\hline 5 & F3 & 1 & 1 & C & - & \\
\hline 3 & F1-3 & 3 & 3 & C & - & \\
\hline 16 & WG3. INTEGER & 4 & 4 & C & - & \\
\hline 21 & WG3.DECIMAL & 2 & 2 & C & - & \\
\hline 76 & WS 3. INTEGER & 4 & 4 & C & - & \\
\hline 81 & WS 3. DECIMAL & 2 & 2 & C & - & \\
\hline 136 & RS3. INTEGER & 4 & 4 & C & - & \\
\hline 141 & RS3.DECIMAL & 2 & 2 & C & - & \\
\hline 6 & DATA & 273 & 200 & C & - & \\
\hline 1 & W1 & 1 & 1 & C & - & \\
\hline 1 & W1 - 2 & 2 & 2 & C & - & \\
\hline 1 & ID & 10 & 10 & I & - & \\
\hline
\end{tabular}


DATAFILE NAME: WIN

22 ITEMS: STARTING IN POSITION 1 COL ITEM NAME

WDTH OPUT TYP N.DEC ALTERNATE NAME

1 WATSHD. UNIT

3 FEDID

11 YEAR

13 INW. GWNAD3

23 INW. GWNAD2

63 INW. GWNAD1

68 INW. GWNY

73 INW. SWNAD3

83 INW. SWNAD2

123 INW. SWNAD1

128 INW. SWNY

133 INR. SWNAD3

143 INR. SWNAD2

183 INR. SWNADI

188 INR. SWNY

193 INW.GWRV

203 INW.GWEV

213 INW.GWEI

218 INW. SWRV

228 INW. SWEV

238 INW. SWEI

243 DUMMYO

22 I -

$8 \quad 8$ I

$22 \mathrm{I}$

$10 \quad 10 \quad \mathrm{~N}$

$40 \quad 40 \quad \mathrm{C}$

55 I

$5 \quad 5$ I

$10-10 \quad \mathrm{~N}$

$40 \quad 40 \quad \mathrm{C}$

** REDEFINED

$\begin{aligned} 3 & \text { F1 } \\ 4 & \text { F2 } \\ 5 & \text { F3 } \\ 3 & \text { F1 }-3 \\ 3 & \text { W1 -8 } \\ 16 & \text { WG3. INTEGER } \\ 21 & \text { WG3. DECIMAL } \\ 76 & \text { WS3. INTEGER } \\ 81 & \text { WS3.DECIMAL } \\ 136 & \text { RS3. INTEGER } \\ 141 & \text { RS3.DECIMAL } \\ 6 & \text { DATA } \\ 1 & \text { ID }\end{aligned}$

ITEMS

55 I

555

$10 \quad 10 \mathrm{~N}$

$40 \quad 40 \quad \mathrm{C}$

55 I

555

$10 \quad 10 \mathrm{~N}$

1010

55

$1010 \mathrm{~N}$

$\begin{array}{llll}10 & 10 & \mathrm{~N} & 2\end{array}$

$55 \mathrm{I}$ -

$100100 \mathrm{C}$

$11 \mathrm{C}$

$11 \mathrm{C}$

$1 \quad 1 \quad C$

$33 \quad \mathrm{C}$

$8 \quad 8 \quad C$

$44 \mathrm{C}$

$22 \quad \mathrm{C}$

$44 \quad \mathrm{C}$

$22 \mathrm{C}$

$44 \mathrm{C}$

$22 \quad \mathrm{C}$

$273200 \quad \mathrm{C}$

1 ID

$1010 \quad \mathrm{I}$ 
DATAFILE NAME: WMI

22 ITEMS: STARTING IN POSITION 1

COL ITEM NAME

1 WATSHD.UNIT

3 FEDID

11 YEAR

13 MIW.GWNAD3

23 MIW. GWNAD2

63 MIW.GWNAD1

68 MIW. GWNY

73 MIW. SWNAD3

83 MIW. SWNAD2

123 MIW. SWNAD1

128 MIW. SWNY

133 MIR. SWNAD3

143 MIR. SWNAD2

183 MIR. SWNAD1

188 MIR. SWNY

193 MIW.GWRV

203 MIW.GWEV

213 MIW. GWEI

218 MIW.SWRV

228 MIW. SWEV

238 MIW. SWEI

243 DUMMYO

WDTH OPUT TYP N.DEC ALTERNATE NAME

** REFEFINED

$\begin{array}{rrrr}2 & 2 & \mathrm{I} & - \\ 8 & 8 & \mathrm{I} & - \\ 2 & 2 & \mathrm{I} & - \\ 10 & 10 & \mathrm{~N} & 2 \\ 40 & 40 & \mathrm{C} & - \\ 5 & 5 & \mathrm{I} & - \\ 5 & 5 & \mathrm{I} & - \\ 10 & 10 & \mathrm{~N} & 2 \\ 40 & 40 & \mathrm{C} & - \\ 5 & 5 & \mathrm{I} & - \\ 5 & 5 & \mathrm{I} & - \\ 10 & 10 & \mathrm{~N} & 2 \\ 40 & 40 & \mathrm{C} & - \\ 5 & 5 & \mathrm{I} & - \\ 5 & 5 & \mathrm{I} & - \\ 10 & 10 & \mathrm{~N} & 2 \\ 10 & 10 & \mathrm{~N} & 2 \\ 5 & 5 & \mathrm{I} & - \\ 10 & 10 & \mathrm{~N} & 2 \\ 10 & 10 & \mathrm{~N} & 2 \\ 5 & 5 & \mathrm{I} & - \\ 100 & 100 & \mathrm{C} & - \\ * * & & & \end{array}$

$\begin{aligned} 3 & \text { F1 } \\ 3 & \text { W1 -8 } \\ 4 & \text { F2 } \\ 5 & \text { F3 } \\ 3 & \text { F1-3 } \\ 16 & \text { WGS. INTEGER } \\ 21 & \text { WG3. DECIMAL } \\ 76 & \text { WS3. INTEGER } \\ 81 & \text { WS3. DECIMAL } \\ 136 & \text { RS3. INTEGER } \\ 141 & \text { RS3. DECIMAL } \\ 6 & \text { DATA } \\ 1 & \text { ID }\end{aligned}$

$\begin{array}{rrrr}1 & 1 & C & - \\ 8 & 8 & C & - \\ 1 & 1 & C & - \\ 1 & 1 & C & - \\ 3 & 3 & C & - \\ 4 & 4 & C & - \\ 2 & 2 & C & - \\ 4 & 4 & C & - \\ 2 & 2 & C & - \\ 4 & 4 & C & - \\ 2 & 2 & C & - \\ 273 & 200 & C & - \\ 10 & 10 & \text { I } & -\end{array}$


DATAFILE NAME: WPF

22 ITEMS: STARTING IN POSITION 1

COL ITEM NAME

1 WATSHD.UNIT

3 FEDID

11 YEAR

13 PFW. GWNAD3

23 PFW. GWNAD2

63 PFW. GWNAD1

68 PFW. GWNY

73 PFW. SWNAD3

83 PFW. SWNAD2

123 PFW. SWNAD1

128 PFW. SWNY

133 PFR. SWNAD3

143 PFR. SWNAD2

183 PFR. SWNAD1

188 PFR. SWNY

193 PFW.GWRV

203 PFW.GWEV

213 PFW.GWEI

218 PFW.SWRV

228 PFW.SWEV

238 PFW. SWEI

WDTH OPUT

243 DUMMYO

$\begin{array}{lll}2 & 2 & \mathrm{I} \\ 8 & 8 & \mathrm{I}\end{array}$

22

$\begin{array}{llll}10 & 10 & N & 2\end{array}$

$40 \quad 40 \quad \mathrm{C}$.

** REDEFINED ITEMS

555

$\begin{array}{lll}5 & 5 & \text { I }\end{array}$

$\begin{array}{llll}10 & 10 & \mathrm{~N} & 2\end{array}$

4040 C -

3 F1

3 W1 - 8

4 F2

5 F3

3 F1-3

16 WG3. INTEGER

21 WG3. DECIMAL

76 WG3. INTEGER

81 WS3. DECIMAL

136 RS3. INTEGER

141 RS3. DECIMAL

6 DATA

1 W1

1 W1-2

1 ID

$\begin{array}{rrrr}1 & 1 & \mathrm{C} & - \\ 8 & 8 & \mathrm{C} & - \\ 1 & 1 & \mathrm{C} & - \\ 1 & 1 & \mathrm{C} & - \\ 3 & 3 & \mathrm{C} & - \\ 4 & 4 & \mathrm{C} & - \\ 2 & 2 & \mathrm{C} & - \\ 4 & 4 & \mathrm{C} & - \\ 2 & 2 & \mathrm{C} & - \\ 4 & 4 & \mathrm{C} & - \\ 2 & 2 & \mathrm{C} & - \\ 273 & 200 & \mathrm{C} & - \\ 1 & 1 & \mathrm{C} & - \\ 2 & 2 & \mathrm{C} & - \\ 10 & 10 & \mathrm{I} & -\end{array}$


DATAFILE NAME: WST

24 ITEMS: STARTING IN POSITION 1 COI ITEM NAME

1 WATSHD. UNIT

3 FEDID

11 YEAR

13 STW. SWNAD3

23 STW.GWNAD2

63 STW. GWNAD1

68 STW. GWNY

73 STW. SWNAD3

83 STW. SWNAD2

123 STW. SWNAD1

128 STW. SWNY

133 STR. SWNAD3

143 STR. SWNAD2

183 STR. SWNAD1

188 STR. SWNY

193 STW.GWRV

203 STW.GWEV

213 STW. GWEI

218 STW. SWRV

228 STW. SWEV

238 STW. SWEI

243 POP. SERVE

250 SERVICE. CONN

257 DUMMYO

WDTH OPUT TYP N.DEC ALTERNATE NAME

** REDEFINED ITEMS **

$\begin{array}{rrrr}2 & 2 & \mathrm{I} & - \\ 8 & 8 & \mathrm{I} & - \\ 2 & 2 & \mathrm{I} & - \\ 10 & 10 & \mathrm{~N} & 2 \\ 40 & 40 & \mathrm{C} & - \\ 5 & 5 & \mathrm{I} & - \\ 5 & 5 & \mathrm{I} & - \\ 10 & 10 & \mathrm{~N} & 2 \\ 40 & 40 & \mathrm{C} & - \\ 5 & 5 & \mathrm{I} & - \\ 5 & 5 & \mathrm{I} & - \\ 10 & 10 & \mathrm{~N} & 2 \\ 40 & 40 & \mathrm{C} & - \\ 5 & 5 & \mathrm{I} & - \\ 5 & 5 & \mathrm{I} & - \\ 10 & 10 & \mathrm{~N} & 2 \\ 10 & 10 & \mathrm{~N} & 2 \\ 5 & 5 & \mathrm{I} & - \\ 10 & 10 & \mathrm{~N} & 2 \\ 10 & 10 & \mathrm{~N} & 2 \\ 5 & 5 & \mathrm{I} & - \\ 7 & 7 & \mathrm{I} & - \\ 7 & 7 & \mathrm{I} & - \\ 100 & 100 & \mathrm{C} & - \\ * * & & & \\ 10 & 10 & 1 & -\end{array}$

1 ID

3 F1

3 W1 - 8

4 F2

5 F3

3 F1-3

16 WG3. INTEGER

21 WG3.DECIMAL

76 WS3. INTEGER

81 WS3.DECIMAL

6 DATA

136 RS3. INTEGER

141 RS3.DECIMAL

$\begin{array}{rrr}10 & 10 & 1 \\ 1 & 1 & C \\ 8 & 8 & C \\ 1 & 1 & C \\ 1 & 1 & C \\ 3 & 3 & C \\ 4 & 4 & C \\ 2 & 2 & C \\ 4 & 4 & C \\ 2 & 2 & C \\ 273 & 200 & C \\ 4 & 4 & C \\ 2 & 2 & C\end{array}$


DATAFILE NAME: WIR

38 ITEMS: STARTING IN POSITION 1

COL ITEM NAME

1 WATSHD. UNIT

3 FEDID

11 YEAR

13 IRW. GWNAD3

23 IRW. GWNAD2

63 IRW. GWNAD1

68 IRW. GWNY

73 IRW. SWNAD3

83 IRW. SWNAD2

123 IRW. SWNAD1

128 IRW. SWNY

133 IRR. SWNAD3

143 IRR. SWNAD2

183 CO.ACRE.S

189 CO.ACRE.G

195 REP.ACRE.S

201 REP.ACRE.G

207 PERM.ACRE.S

213 PERM.ACRE.G

219 PCNT. IRR. ACRE.S

225 PCNT.IRR.ACRE.G

231 EST.ACRE.S

237 EST.ACRE.G

243 REP.WAT.S

253 REP.WAT.G

263 GAL.ACRE.S

273 GAL.ACRE.G

283 GAL.ACRE.R

293 EST.WAT.S

303 EST.WAT.G

313 ALL.ACRE.S

319 ALL.ACRE.G

325 ALL. WAT.S

335 ALL.WAT.G

345 ALL.WAT.R

355 IN.ACRE. NORICE

361 IN.ACRE.RICE

367 DUMMYO ** REDEFINED ITEMS
WDTH OPUT TYP N.DEC ALTERNATE NAME

$\begin{array}{rrrr}2 & 2 & \mathrm{I} & - \\ 8 & 8 & \mathrm{I} & - \\ 2 & 2 & \mathrm{I} & - \\ 10 & 10 & \mathrm{~N} & 2\end{array}$

$40 \quad 40$

$\begin{array}{llll}5 & 5 & I & -\end{array}$

$10 \quad 10 \quad \mathrm{~N} \quad 2$

$40 \quad 40 \quad \mathrm{C} \quad-$

55 I -

5 5 I -

$\begin{array}{llll}10 & 10 & \mathrm{~N} & 2\end{array}$

$40 \quad 40 \quad \mathrm{C} \quad-$

$\begin{array}{llll}6 & 6 & \mathrm{I}\end{array}$

$\begin{array}{lll}6 & 6 & \text { I }\end{array}$

$\begin{array}{lll}6 & 6 & \mathrm{I}\end{array}$

$\begin{array}{lll}6 & \mathrm{I}\end{array}$

$6 \quad 6 \quad I$.

$\begin{array}{llll}6 & 6 & \mathrm{I} & -\end{array}$

$\begin{array}{llll}6 & 6 & \mathrm{~N} & 2\end{array}$

$\begin{array}{llll}6 & 6 & \mathrm{~N} & 2\end{array}$

$6 \quad 6$ I -

$\begin{array}{llll}6 & 6 & \mathrm{I} & -\end{array}$

$\begin{array}{llll}10 & 10 & \mathrm{~N} & 2\end{array}$

$\begin{array}{llll}10 & 10 & \mathrm{~N} & 2\end{array}$

$\begin{array}{llll}10 & 10 & \mathrm{~N} & 2\end{array}$

$\begin{array}{llll}10 & 10 & \mathrm{~N} & 2\end{array}$

$\begin{array}{llll}10 & 10 & \mathrm{~N} & 2\end{array}$

$\begin{array}{llll}10 & 10 & \mathrm{~N} & 2\end{array}$

$\begin{array}{llll}10 & 10 & \mathrm{~N} & 2\end{array}$

66 I -

$6 \quad 6$ I -

$\begin{array}{llll}10 & 10 & \mathrm{~N} & 2\end{array}$

$\begin{array}{llll}10 & 10 & \mathrm{~N} & 2\end{array}$

$\begin{array}{llll}10 & 10 & \mathrm{~N} & 2\end{array}$

$\begin{array}{llll}6 & 6 & \mathrm{~N} & 2\end{array}$

$\begin{array}{llll}6 & 6 & \mathrm{~N} & 2\end{array}$

$100100 \mathrm{C}$.

$\begin{array}{rl}1 & \text { ID } \\ 3 & F 1 \\ 3 & \text { W1 -8 } \\ 4 & \text { F2 } \\ 5 & \text { F3 } \\ 3 & \text { F1 -3 } \\ 16 & \text { WG3. INTEGER } \\ 21 & \text { WG3.DECIMAL } \\ 76 & \text { WS3. INTEGER } \\ 81 & \text { WS3.DECIMAL } \\ 136 & \text { RS3. INTEGER } \\ 141 & \text { RS3.DECIMAL } \\ 6 & \text { DATA }\end{array}$

$\begin{array}{rrrr}10 & 10 & \text { I } & - \\ 1 & 1 & \text { C } & - \\ 8 & 8 & \text { C } & - \\ 1 & 1 & \text { C } & - \\ 1 & 1 & \text { C } & - \\ 3 & 3 & \text { C } & - \\ 4 & 4 & \text { C } & - \\ 2 & 2 & \text { C } & - \\ 4 & 4 & \text { C } & - \\ 2 & 2 & \text { C } & - \\ 4 & 4 & \text { C } & - \\ 2 & 2 & \text { C } & - \\ 273 & 200 & \text { C } & -\end{array}$


DATAFILE NAME: WIR2

38 ITEMS: STARTING IN POSITION 1 COL ITEM NAME

$\begin{array}{rlrrrr}1 & \text { WATSHD.UNIT } & 2 & 2 & \mathrm{I} & - \\ 3 & \text { FEDID } & 8 & 8 & \mathrm{I} & - \\ 11 & \text { YEAR } & 2 & 2 & \mathrm{I} & - \\ 13 & \text { IRW.GWNAD3 } & 10 & 10 & \mathrm{~N} & 2 \\ 23 & \text { IRW.GWNAD2 } & 40 & 40 & \mathrm{C} & - \\ 63 & \text { IRW.GWNAD1 } & 5 & 5 & \mathrm{I} & - \\ 68 & \text { IRW.GWNY } & 5 & 5 & \mathrm{I} & - \\ 73 & \text { IRW.SWNAD3 } & 10 & 10 & \mathrm{~N} & 2 \\ 83 & \text { IRW.SWNAD2 } & 40 & 40 & \mathrm{C} & - \\ 123 & \text { IRW.SWNAD1 } & 5 & 5 & \mathrm{I} & - \\ 128 & \text { IRW.SWNY } & 5 & 5 & \mathrm{I} & - \\ 133 & \text { IRR.SWNAD3 } & 10 & 10 & \mathrm{~N} & 2 \\ 143 & \text { IRR.SWNAD2 } & 40 & 40 & \mathrm{C} & - \\ 183 & \text { CO.ACRE.S } & 6 & 6 & \mathrm{I} & - \\ 189 & \text { CO.ACRE.G } & 6 & 6 & \mathrm{I} & - \\ 195 & \text { REP.ACRE.S } & 6 & 6 & \mathrm{I} & - \\ 201 & \text { REP.ACRE.G } & 6 & 6 & \mathrm{I} & - \\ 207 & \text { PERM.ACRE.S } & 6 & 6 & \mathrm{I} & - \\ 213 & \text { PERM.ACRE.G } & 6 & 6 & \mathrm{I} & - \\ 219 & \text { PCNT.IRR.ACRE.S } & 6 & 6 & \mathrm{~N} & 2 \\ 225 & \text { PCNT.IRR.ACRE.G } & 6 & 6 & \mathrm{~N} & 2 \\ 231 & \text { EST.ACRE.S } & 6 & 6 & \mathrm{I} & - \\ 237 & \text { EST.ACRE.G } & 6 & 6 & \mathrm{I} & - \\ 243 & \text { REP.WAT.S } & 10 & 10 & \mathrm{~N} & 2 \\ 253 & \text { REP.WAT.G } & 10 & 10 & \mathrm{~N} & 2 \\ 263 & \text { GAL.ACRE.S } & 10 & 10 & \mathrm{~N} & 2 \\ 273 & \text { GAL.ACRE.G } & 10 & 10 & \mathrm{~N} & 2 \\ 283 & \text { GAL.ACRE.R } & 10 & 10 & \mathrm{~N} & 2 \\ 293 & \text { EST.WAT.S } & 10 & 10 & \mathrm{~N} & 2 \\ 303 & \text { EST.WAT.G } & 10 & 10 & \mathrm{~N} & 2 \\ 313 & \text { ALL.ACRE.S } & 6 & 6 & \mathrm{I} & - \\ 319 & \text { ALL.ACRE.G } & 6 & 6 & \mathrm{I} & - \\ 325 & \text { ALL.WAT.S } & 10 & 10 & \mathrm{~N} & 2 \\ 335 & \text { ALL.WAT.G } & 10 & 10 & \mathrm{~N} & 2 \\ 345 & \text { ALL.WAT.R } & 10 & 10 & \mathrm{~N} & 2 \\ 355 & \text { IN.ACRE.NORICE } & 6 & 6 & \mathrm{~N} & 2 \\ 361 & \text { IN.ACRE.RICE } & 6 & 6 & \mathrm{~N} & 2 \\ 367 & \text { DUMMYO } & 100 & 100 & \mathrm{C} & - \\ & \text { ** REDEFINED ITEMS } & * * & & & \end{array}$

** REDEFINED ITEMS **

$\begin{array}{rlrrrr}1 & \text { ID } & 10 & 10 & 1 & - \\ 3 & \text { F1 } & 1 & 1 & \mathrm{C} & - \\ 3 & \text { W1-8 } & 8 & 8 & \mathrm{C} & - \\ 4 & \text { F2 } & 1 & 1 & \mathrm{C} & - \\ 5 & \text { F3 } & 1 & 1 & \mathrm{C} & - \\ 3 & \text { F1-3 } & 3 & 3 & \mathrm{C} & - \\ 16 & \text { WG3.INTEGER } & 4 & 4 & \mathrm{C} & - \\ 21 & \text { WG3. DECIMAL } & 2 & 2 & \mathrm{C} & - \\ 76 & \text { WS3. INTEGER } & 4 & 4 & \mathrm{C} & - \\ 81 & \text { WS3.DECIMAL } & 2 & 2 & \mathrm{C} & - \\ 136 & \text { RS3. INTEGER } & 4 & 4 & \mathrm{C} & - \\ 141 & \text { RS3.DECIMAL } & 2 & 2 & \mathrm{C} & - \\ 6 & \text { DATA } & 273 & 200 & \mathrm{C} & -\end{array}$


DATAFILE NAME: WIRC

38 ITEMS: STARTING IN POSITION 1

COL ITEM NAME

WDTH OPUT TYP N.DEC ALTERNATE NAME

1 WATSHD.UNIT

3 FEDID

11 YEAR

13 IRW. GWNAD3

23 IRW. GWNAD2

63 IRW. GWNAD1

68 IRW. GWNY

73 IRW. SWNAD3

83 IRW. SWNAD2

123 IRW. SWNADI

128 IRW. SWNY

133 IRR. SWNAD3

143 IRR. SWNAD2

183 CO.ACRE.S

189 COACRE.G

195 REP.ACRE.S

201 REP.ACRE.G

207 PERM.ACRE.S

213 PERM. ACRE.G

219 PCNT. IRR. ACRE.S

225 PCNT.IRR.ACRE.G

231 EST.ACRE.S

237 EST.ACRE.G

243 REP.WAT.S

253 REP.WAT.G.

263 GAL.ACRE.S

273 GAL.ACRE.G

283 GAL.ACRE.R

293 EST.WAT.S

303 EST.WAT.G

313 ALL. ACRE.S

319 ALL.ACRE.G

325 ALL.WAT.S

335 ALL.WAT.G

345 ALL.WAT.R

355 IN.ACRE. NORICE

361 IN.ACRE.RICE

367 DUMMYO

**REDEFINED ITEMS **

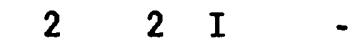

$8 \begin{array}{llll}8 & 8 & I & -\end{array}$

22 I -

$\begin{array}{llll}10 & 10 & N & 2\end{array}$

4040 C -

555 I -

$\begin{array}{llll}5 & 5 & I & -\end{array}$

$\begin{array}{llll}10 & 10 & N & 2\end{array}$

$4040 \mathrm{C}$ -

555 .

555 I -

$\begin{array}{llll}10 & 10 & \mathrm{~N} & 2\end{array}$

4040 C .

66 I .

66 I -

66 I -

66 I -

$\begin{array}{llll}6 & 6 & \mathrm{I}\end{array}$

$6 \quad 6$ I -

$\begin{array}{llll}6 & 6 & \mathrm{~N} & 2\end{array}$

$\begin{array}{llll}6 & 6 & \mathrm{~N} & 2\end{array}$

$6 \quad 6$ I -

$6 \quad 6$ I -

$\begin{array}{rrrr}6 & 6 & \mathrm{~N} & 2\end{array}$

$\begin{array}{llll}10 & 10 & \mathrm{~N} & 2\end{array}$

$\begin{array}{llll}10 & 10 & \mathrm{~N} & 2\end{array}$

$\begin{array}{llll}10 & 10 & \mathrm{~N} & 2\end{array}$

$10 \quad 10 \mathrm{~N} \quad 2$

$10 \quad 10 \mathrm{~N} \quad 2$

$\begin{array}{llll}10 & 10 & \mathrm{~N} & 2\end{array}$

1 ID

3 F1

3 W1-8

4 F2

5 F3

3 F1-3

16 WG3. INTEGER

21 WG3.DECIMAL

76 WS3. INTEGER

81 WS3.DECIMAL

136 RS3. INTEGER

131 RS3.DECIMAL

6 DATA

$\begin{array}{rrrr}10 & 10 & \mathrm{I} & - \\ 1 & 1 & \mathrm{C} & - \\ 8 & 8 & \mathrm{C} & - \\ 1 & 1 & \mathrm{C} & - \\ 1 & 1 & \mathrm{C} & - \\ 3 & 3 & \mathrm{C} & - \\ 4 & 4 & \mathrm{C} & - \\ 2 & 2 & \mathrm{C} & - \\ 4 & 4 & \mathrm{C} & - \\ 2 & 2 & \mathrm{C} & - \\ 4 & 4 & \mathrm{C} & - \\ 2 & 2 & \mathrm{C} & - \\ 273 & 200 & \mathrm{C} & -\end{array}$




\section{WATERSHED AGGREGATION PROGRAMS}

The programs used, as of September 5, 1985, to aggregate data by watershed are on the following pages. 


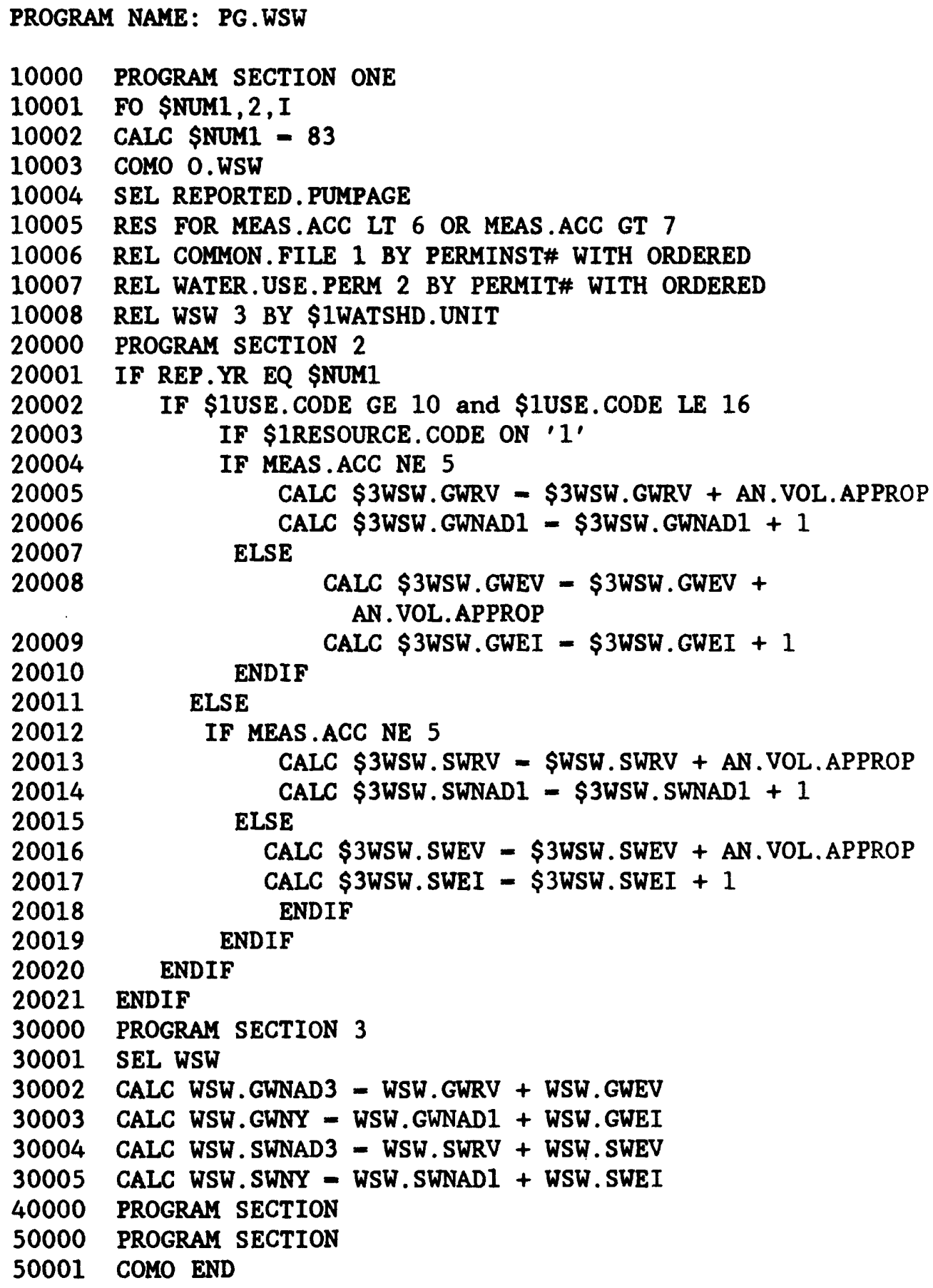


PROGRAM NAME: PG.WMU

10000 PROGRAM SECTION ONE

10001 FO \$NUM1, 2, I

10002 CALC \$NUM1 $=83$

10003 COMO O.WMU

10004 SEL REPORTED. PUMPAGE

10005 RES FOR MEAS.ACC LT 6 OR MEAS.ACC GT 7

10006 REL COMMON.FILE 1 BY PERMINST\# WITH ORDERED

10007 REL WATER.USE.PERM 2 BY PERMIT\# WITH ORDERED

10008 REL WMU 3 BY \$1WATSHD.UNIT WITH ORDERED

20000 PROGRAM SECTION 2

20001 IF REP.YR EQ \$NUM1

20002 IF \#1USE.CODE EQ 11

20003 IF \$1RESOURCE.CODE CN ' 1 '

20004 IF MEAS.ACC NE 5

20005

CALC \$3MUW. GWRV $=$ \$3MUW.GWRV + AN. VOL.APPROP

20006

CALC \$3MUW. GWNAD1 $=$ \$3MUW.GWNAD1 +1

20007

ELSE

20008

CALC \$3MUW. GWEV = \$3MUW.GWEV + AN.VOL.APPROP

20009

CALC \$3MUW. GWEI $=$ \$3MUW. GWEI +1

20010

20011

ENDIF

20012

ELSE

20013

IF MEAS.ACC NE 5

CALC \$3MUW. SWRV $=$ \$3MUW.SWRV + AN. VOL.APPROP

20014

CALC \$3MUW. SWNADI $=$ \$3MUW. SWNAD $1+1$

20015

ELSE

20016

20017

20018

20019

20020

20021 ENDIF

30000 PROGRAM SECTION 3

30001 SEL WMU

30002 CALC MUW. GWNAD $3=$ MUW.GWRV + MUW. GWEV

30003 CALC MUW. GWNY = MUW. GWNAD1 + MUW.GWEI

30004 CALC MUW. SWNAD3 $=$ MUW. SWRV + MUW. SWEV

30005 CALC MUW. SWNY $=$ MUW. SWNAD1 + MUW. SWEI

40000 PROGRAM SECTION 4

50000 PROGRAM SECTION 5

50001 FO \$NUM1, 6, I

50002 SEL REPORTED. PUMPAGE

50003 RES FOR REP.YR EQ 83

50004 RES FOR MEAS.ACC LT 6 OR MEAS.ACC GT 7

50005 CALC \$NM $=1$.

50006 REL COMMON. FILE 1 BY PERMIT\# ORDERED

50007 REL WMU 2 BY \$1WATSHD. UNIT ORDERED

50008 REL WSW 3 BY \$2WATSHD. UNIT ORDERED

50009 REL WATER.USE. PERM 4 BY PERMIT\# ORDERED

50010 CALC $\$ N U M 1=0$

60000 PROGRAM SECTION 6

60001 IF ( \$NUM1 = PERMIT\# )

60002 CALC REP.YR $=38$ 


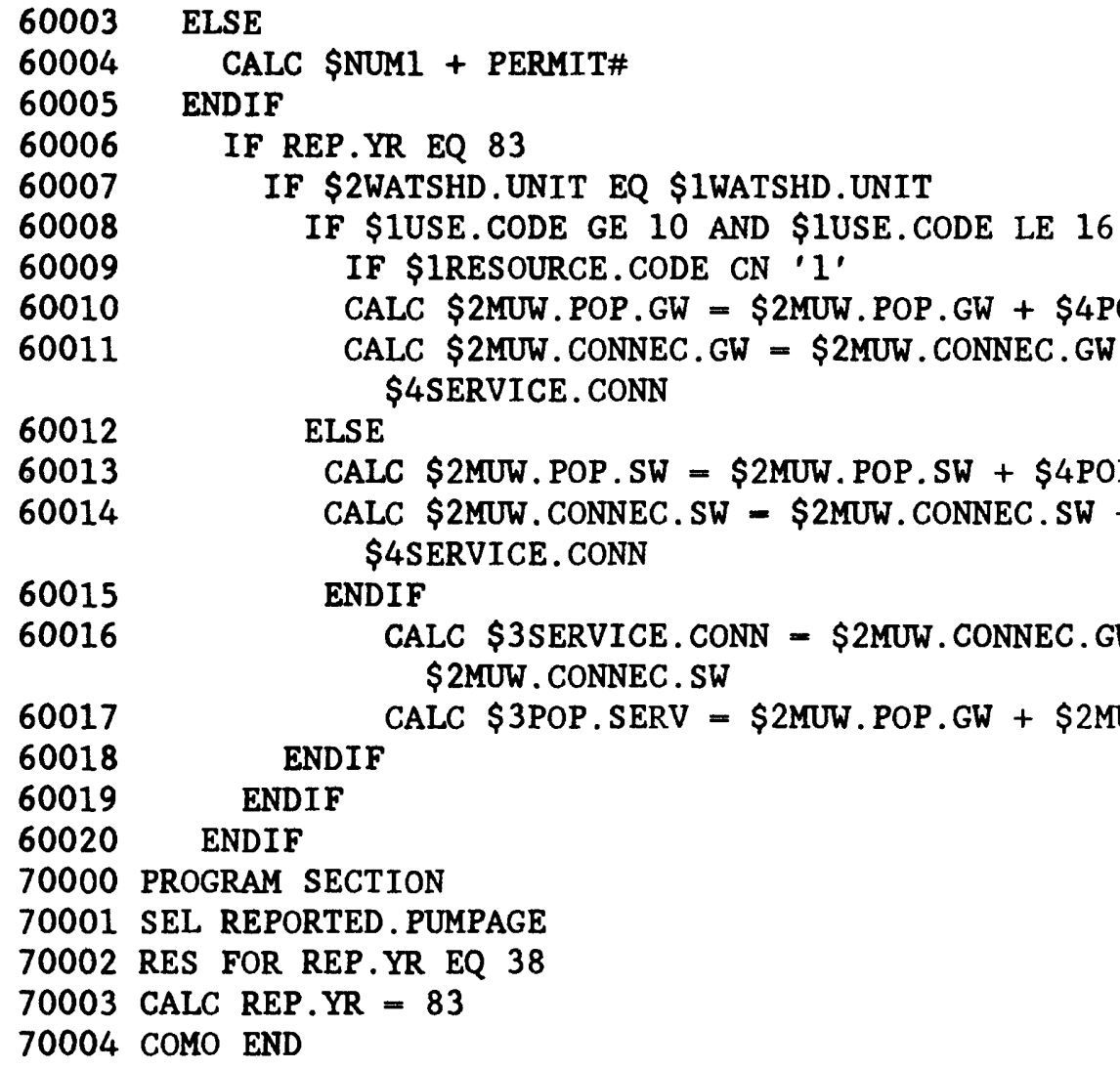


PROGRAM NAME: PG.WAW

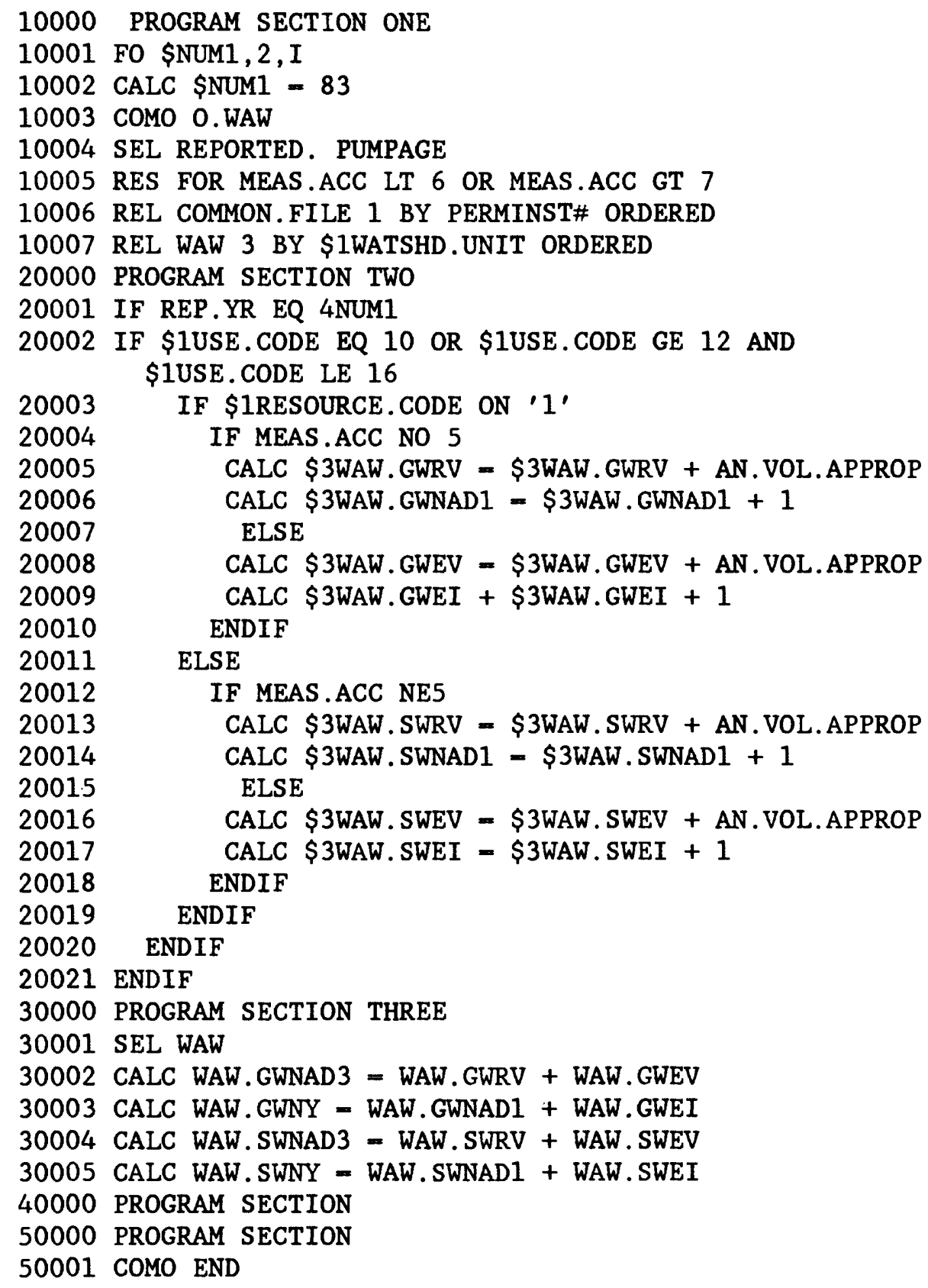


PROGRAM NAME: PG.WCO

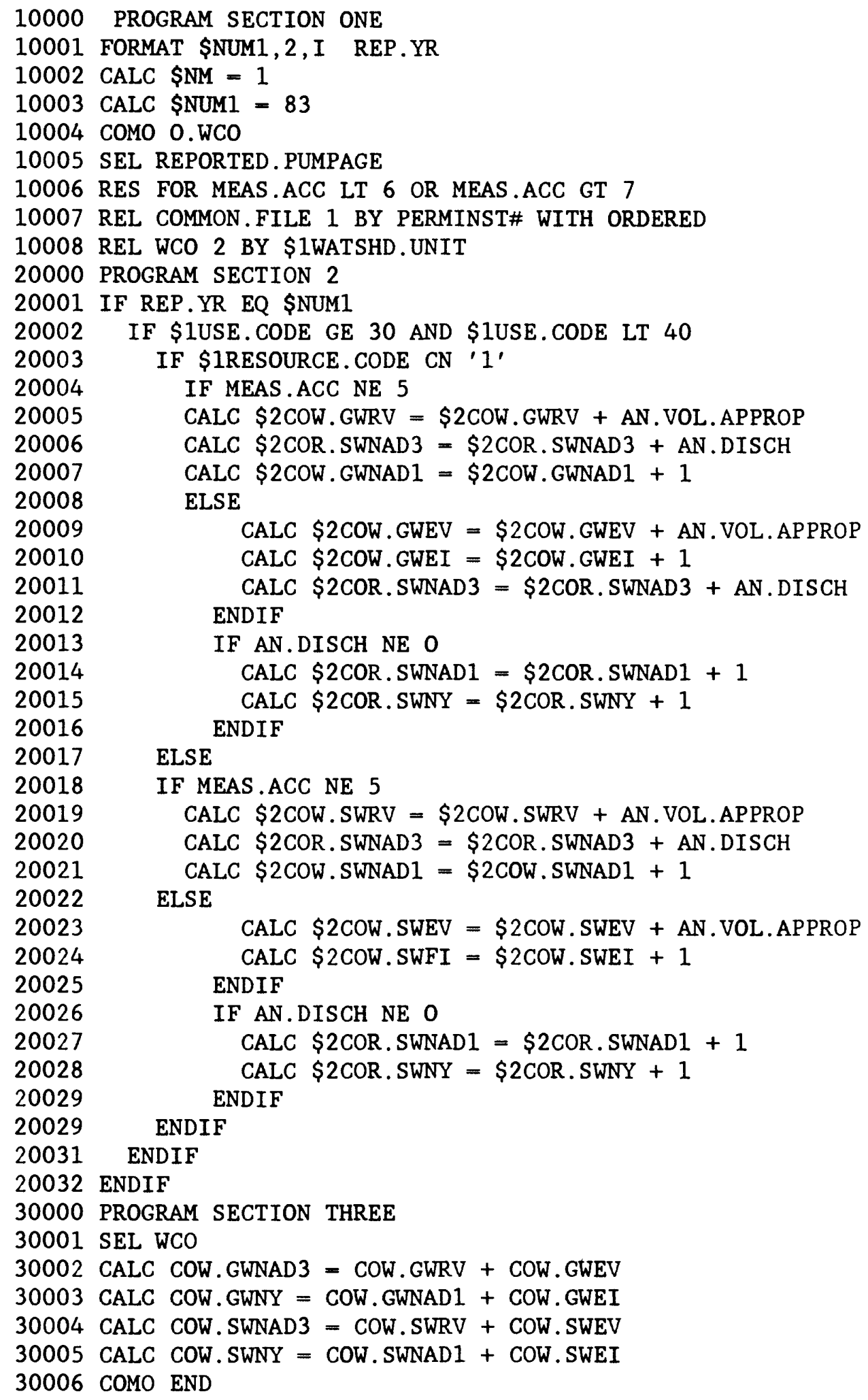


PROGRAM NAME: PG.WIN

10000 PROGRAM SECTION ONE

10001 CALC $\$$ NUM40 $=83$

10002 CALC $\$ N M=1$

10003 COMO O.WIN

10004 SEL REPORTED. PUMPAGE

10005 RES FOR MEAS.ACC LT 6 OR MEAS.ACC GT 7

10006 REL COMMON.FILE 1 BY PERMINST\# WITH ORDERED

10007 REL WIN 2 BY \$1WATSHD. UNIT

20000 PROGRAM SECTION 2

20001 IF REP.YR EQ \$NUM40

20002 IF \$1USE.CODE GE 40 AND \$1USE. CODE LE 42 OR \$IUSE.CODE GE 46 \$1USE.CODE LE 48

20003 IF \$1RESOURCE. CODE ON ' 1 '

20004 IF MEAS.ACC NE 5

20005

CALC \$2INW. GWRV $=$ \$2INW.GWRV + AN. VOL.APPROP

20006

CALC \$2INR. SWNAD3 $=$ \$2INR. SWNAD3 + AN.DISCH

20007

CALC \$2INW.GWNAD1 = \$2INW.GWNAD1 +1

20008

ELSE

20009

CALC \$2INW.GWEV $=$ \$2INW.GWEV + AN. VOL.APPROP

20010

20011

20012

CALC \$2INW.GWEI $=$ \$2INW.GWEI +1

ENDIF

CALC \$2INR. SWNAD3 = \$2INR. SWNAD3 + AN.DISCH

20013

IF AN.DISCH NE $O$

20014

20015

20016

20017

20018

20019

20020

20021

20022

20023

20024

20025

20026

20027

20028

20029

20030

20031

20032

ENDIF

CALC \$2INR. SWNAD1 $=$ \$2INR. SWNAD $1+1$

CALC \$2INR. SWNY $=\$ 2$ INR. SWNY +1

ELSE

IF MEAS . ACC NE5

CALC \$2INW. SWRV $=$ \$2INW. SWRV + AN.VOL.APPROP

CALC \$2INR. SWNAD3 $=\$ 2$ INR. SWNAD3 + AN.DISCH

CALC \$2INW. SWNAD1 $=\$ 2$ INW. SWNAD1 +1

ELSE

30000 PROGRAM SECTION THREE

30001 SEL WIN

30002 CALC INW.GWNAD3 = INW.GWRV + INW. GWEV

30003 CALC INW.GWNY = INW.GWNAD $1+$ INW.GWEI

30004 CALC INW. SWNAD3 = INW.SWRV + INW. SWEV

30005 CALC INW. SWNY = INW. SWNAD $1+$ INW. SWEI

30006 COMO END 


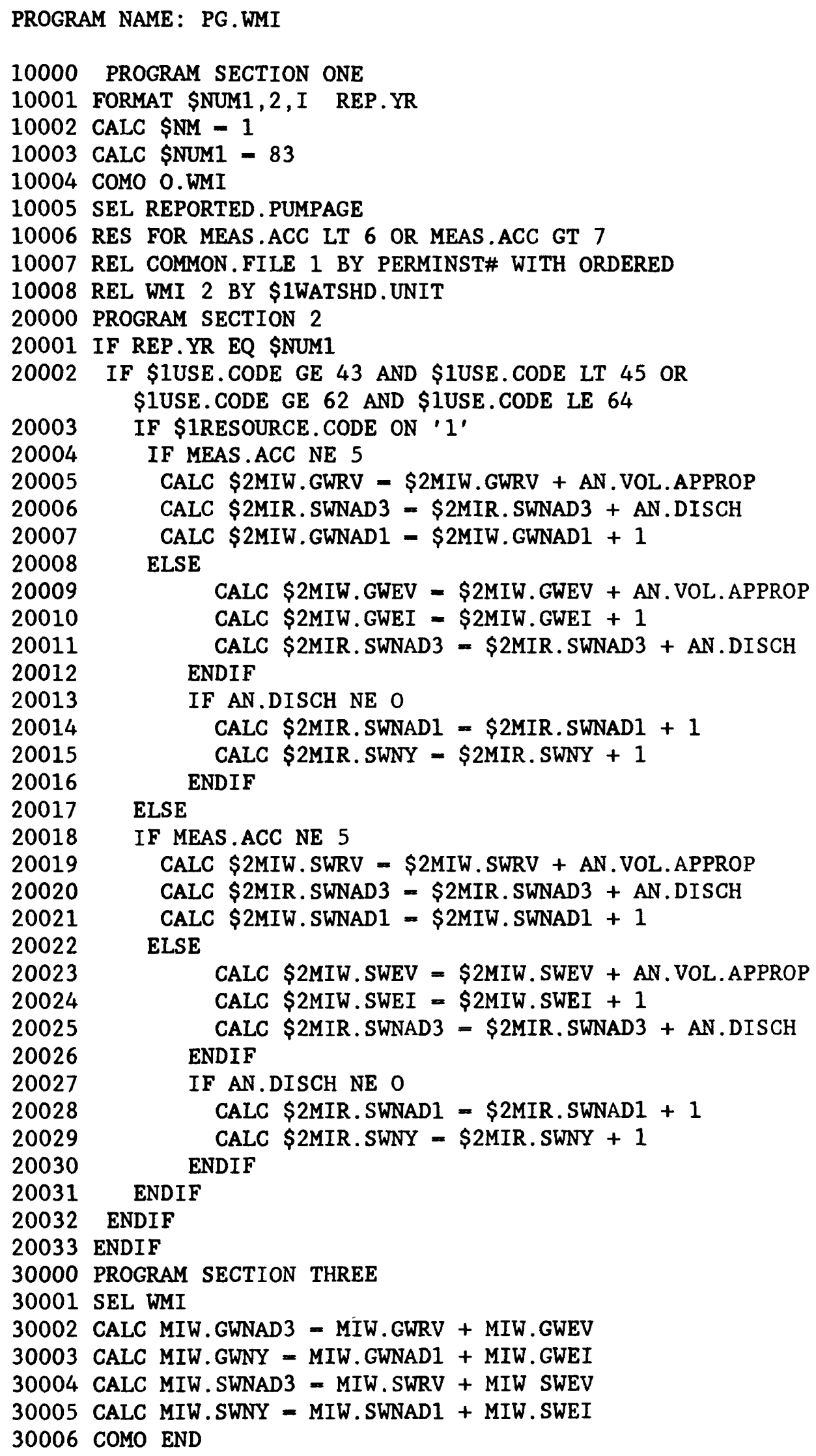


PROGRAM NAME: PG.WPF

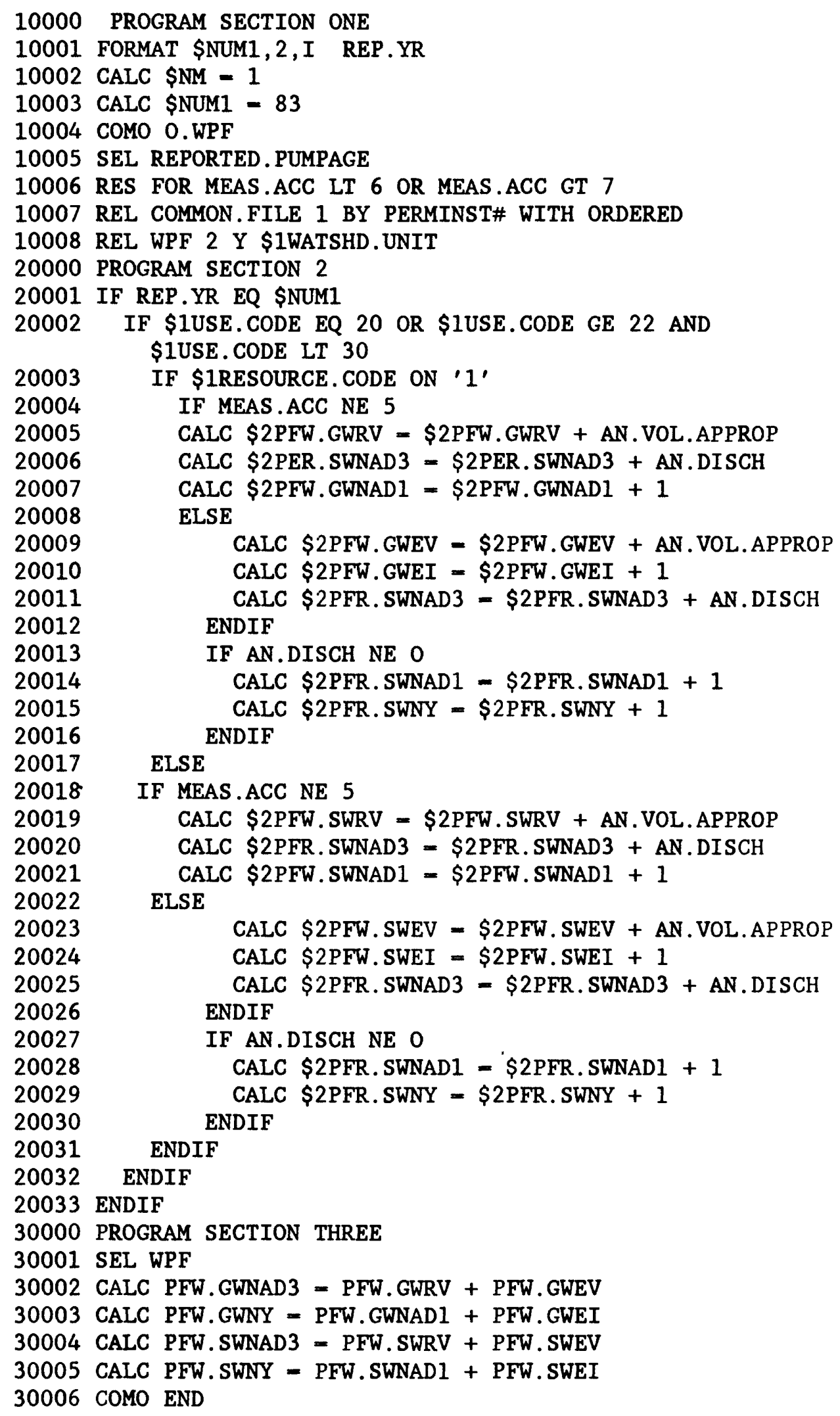


PROGRAM NAME: PG.WST

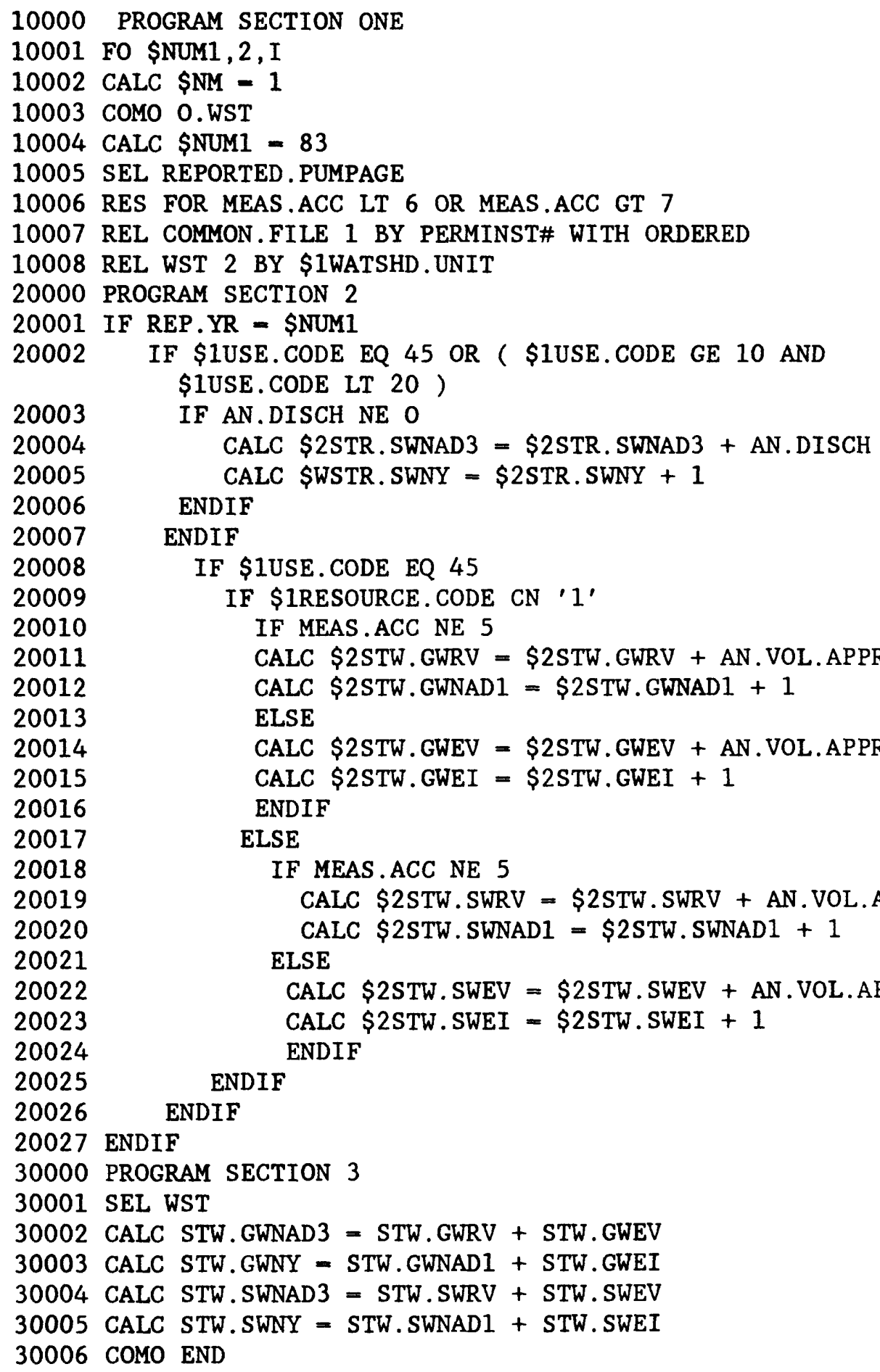


PROGRAM NAME: PG.WIR

10000 PROGRAM SECTION ONE

10001 FO \$NUM1, 2, I

10002 FOR \$NUM2, 6, I

10003 FOR \$NUM3, 6, I

10004 CALC \$NUM1 $=83$

10005 CALC \$NM - 1

10006 COMO O.WIR

10007 SEL WATER.USE. PERM

10008 RES FOR TERM. YEAR EQ 0 OR TERM.YEAR GT 83

10009 REL COMMON, FILE 1 BY PERMIT\# ORDERED

10010 REL WIR 2 BY \$1WATSHD.UNIT

10011 RES FOR \$1USE.CODE EQ 96

20000 PROGRAM SECTION 2

20001

20001

20003

20004

20005

20006

20007

30000 PROGRAM SECTION 3

30001 SEL WATER.USE. PERM

30002 REL COMMON.FILE 1 BY PERMIT\# ORDERED

30003 REL REPORTED.PUMPAGE 2 BY PERMIT\# ORDERED

30004 REL WIR 3 BY \$1WATSHD. UNIT

30005 RES FOR \$IUSE.CODE EQ 96

40000 PROGRAN SECTION 4

40001 IF \$2CROP.ACRE1 NE 0 AND \$2REP. YR EQ 83

40002 IF \$1RESOURCE. CODE CN ' 1 '

40003 CALC \$3PERM.ACRE.G - \$3PERM.ACRE.G + TOT.ACRE

40004

40005

40006

40007

40008

40009

40010

40011

50000 PROGRAM SECTION 5

50001 SEL REPORTED. PUMPAGE

50002 RES FOR REP.YR EQ 83

50003 REL COMMON. FILE 1 BY PERMINST\# ORDERED

50004 REL WIR 2 BY \$1WATSHD. UNIT

50005 RES FOR CROP.ACRE1 GT 0

50006 RES FOR \$1USE. CODE EQ 96

60000 PROGRAM SECTION 4

60001

60002

60003

60004

60005

60006
IF \$1RESOURCE. CODE CN ' 1 '

CALC \$2REP.ACRE.G - \$2REP.ACRE.G + CROP.ACRE1 + CROP.ACRE2 + CROP .ACRE3

IF \$2PERM. ACRE.G GT 0 CALC \$2PCNT. IRR.ACRE.G - \$2REP.ACRE.G / \$2PERM.ACRE.G

ENDIF

CALC \$2EST.ACRE.G - \$2PCNT.IRR.ACRE. G * 


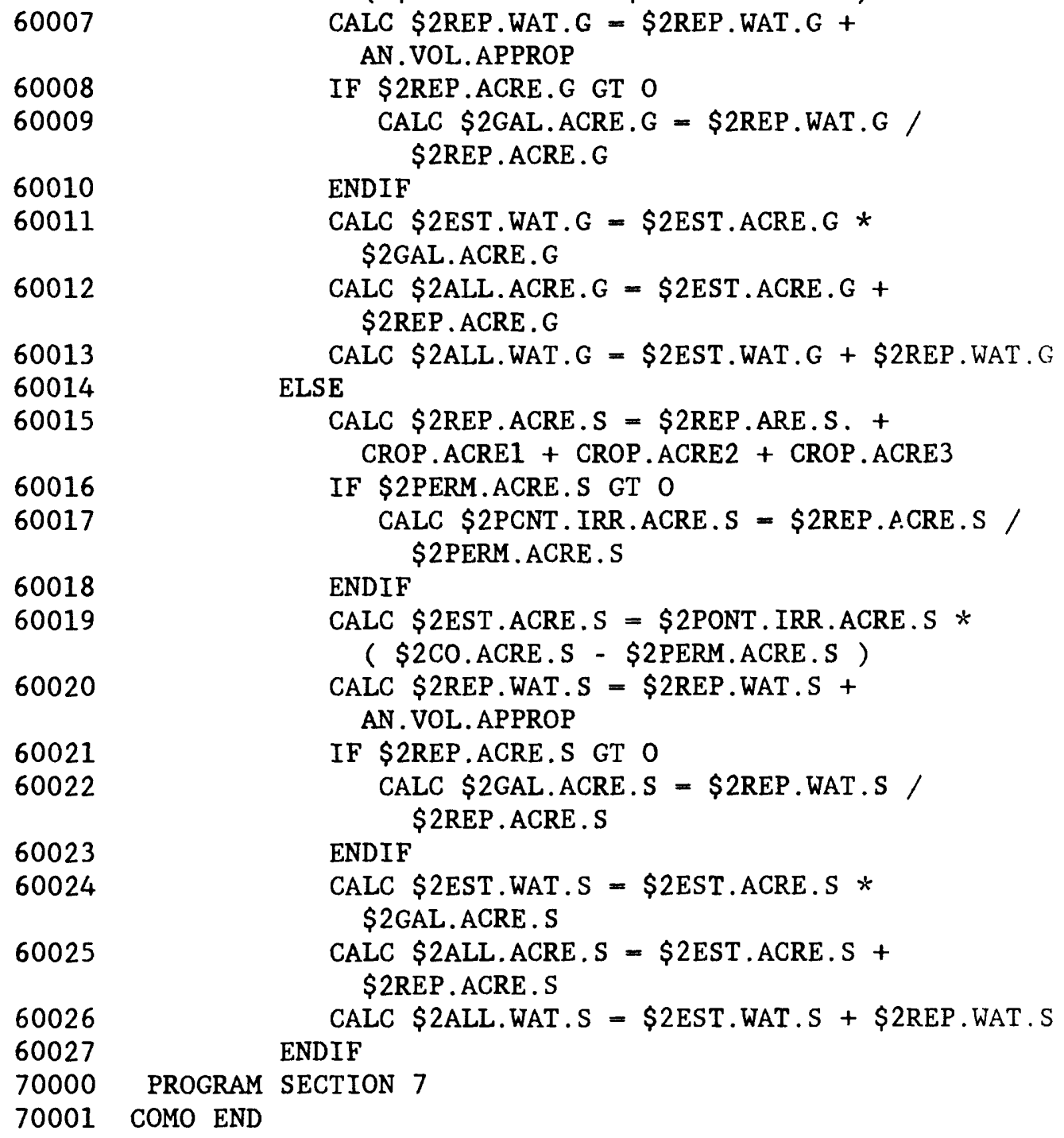


PROGRAM NAME: PG.WIR2

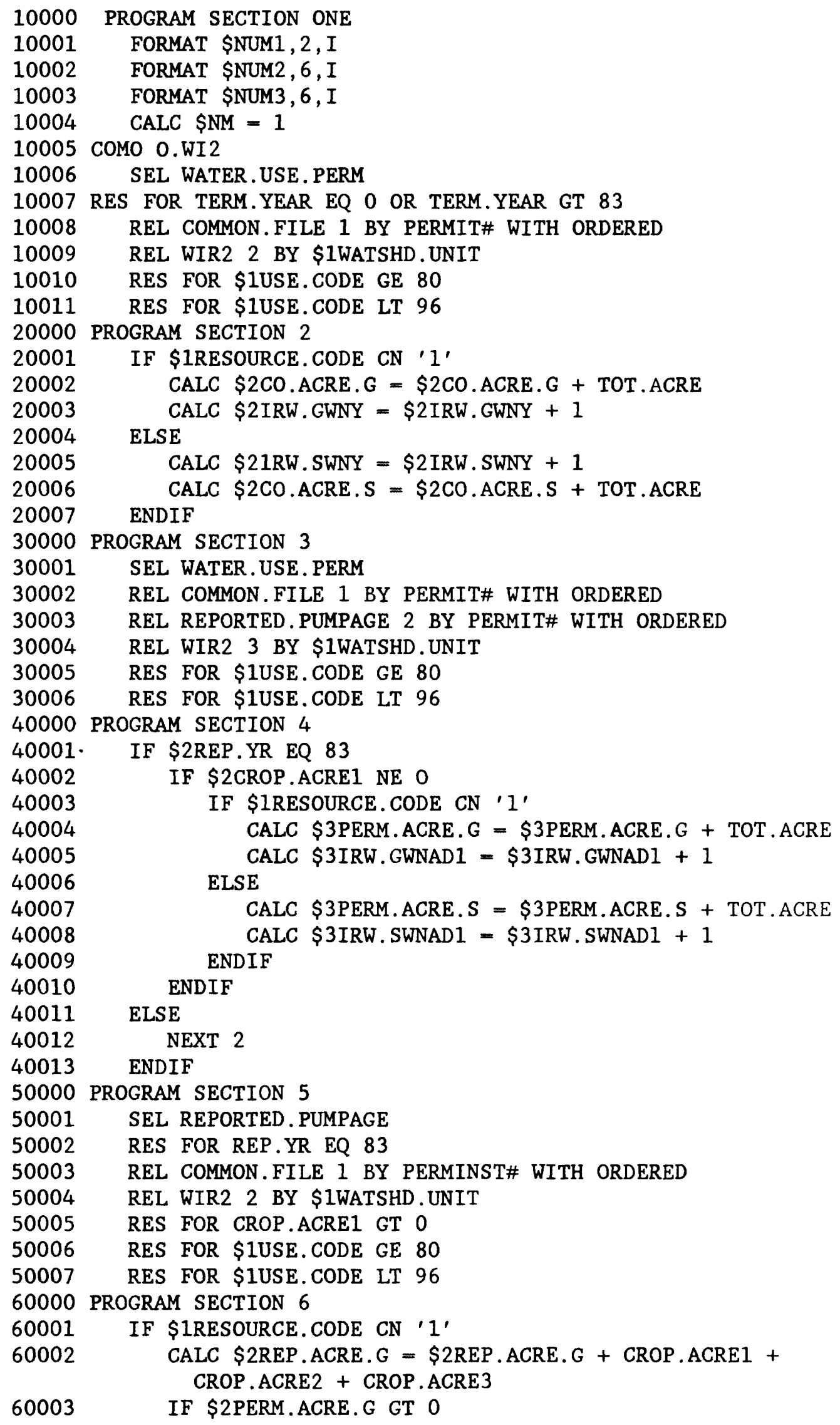




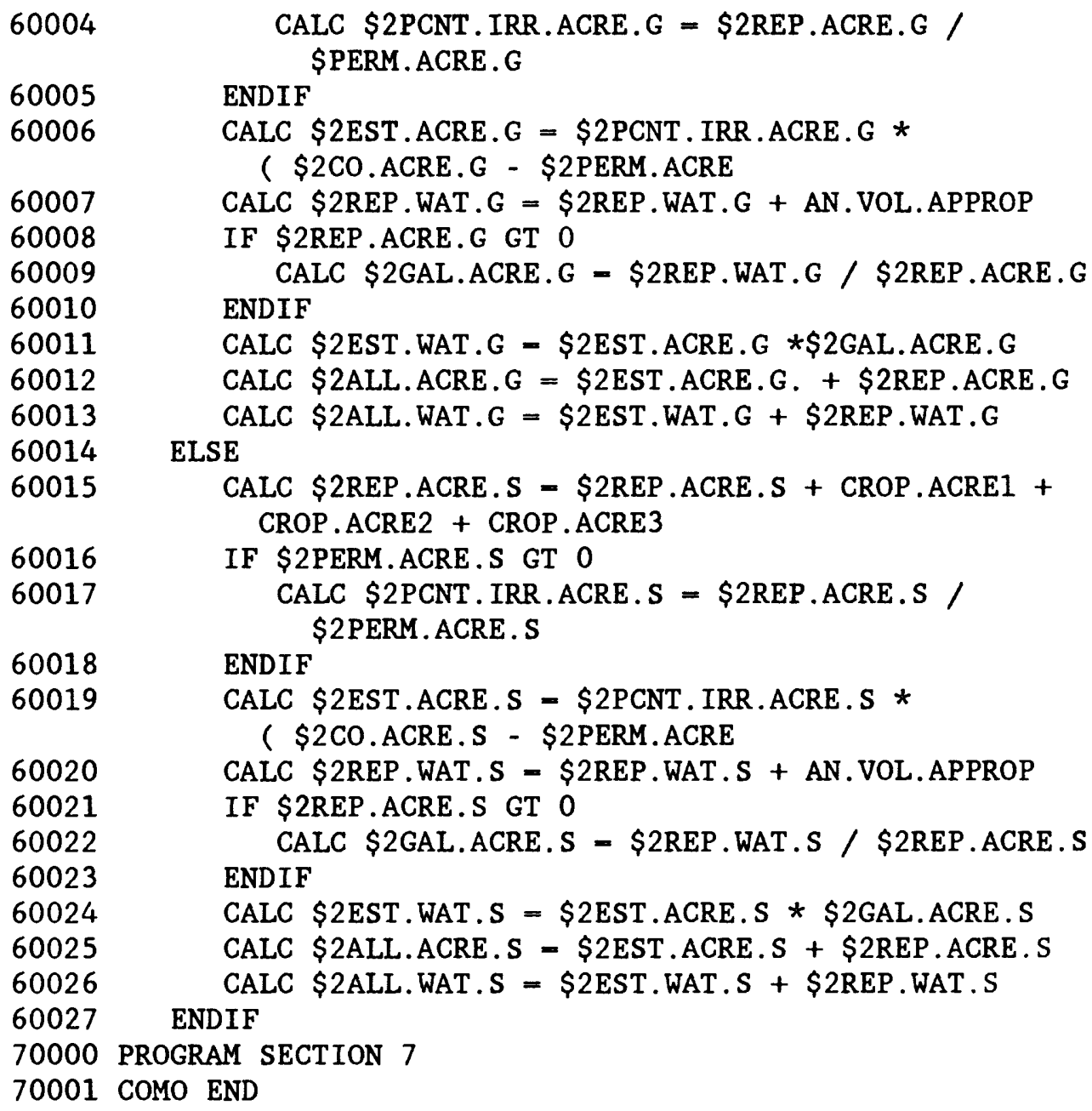


PROGRAM NAME: PG.WIRC

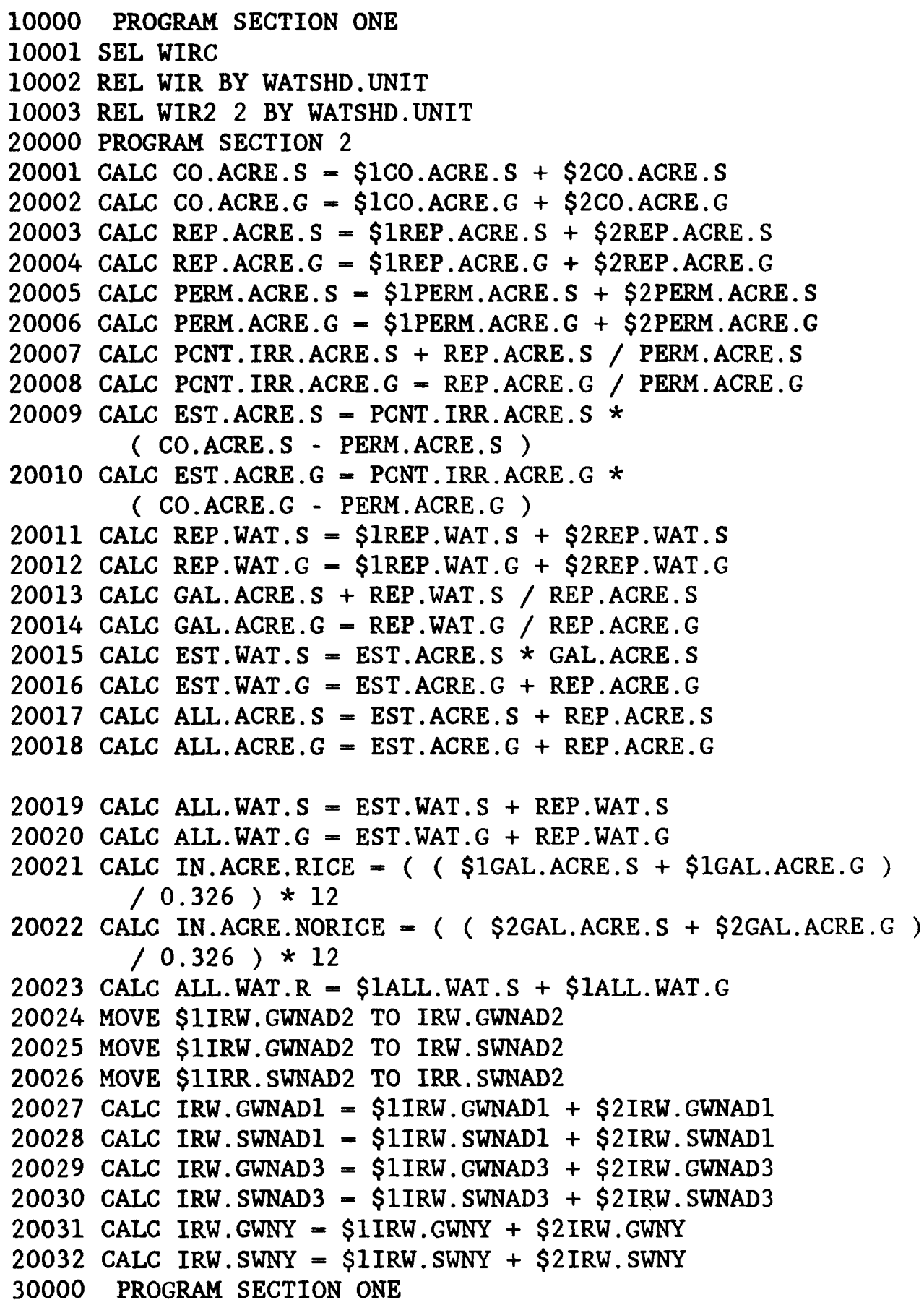

